\title{
Two new species of the Delma tincta group (Squamata: Pygopodidae) from northwestern Australia
}

\author{
Brad Maryan ${ }^{1 *}$, Ken P. Aplin ${ }^{2}$, and Mark Adams ${ }^{3}$ \\ ${ }^{1}$ Department of Terrestrial Vertebrates, Western Australian Museum, \\ Locked Bag 49 Welshpool DC, Perth, WA, 6986, Australia \\ ${ }^{2}$ Australian National Wildlife Collection, CSIRO Division of Sustainable Ecosystems, \\ PO Box 284 Canberra, ACT, 2601, Australia \\ ${ }^{3}$ Evolutionary Biology Unit, South Australian Museum, North Terrace, Adelaide, SA, 5000, Australia \\ * Corresponding author
}

\begin{abstract}
Analysis of allozyme and morphological variation has revealed that two pygopodid lizard species are presently confused under Delma pax Kluge, 1974. Delma pax is redescribed and shown to be confined to the Pilbara region, while a closely related, new species is described from the arid deserts of western and central Australia. A second new species, endemic to the Cape Range Peninsula, is also described. Among Western Australian specimens previously referred to $D$. borea Kluge, 1974, those from the Pilbara islands are confirmed; however, all specimens from the Pilbara mainland and arid desert localities are reallocated to other taxa. Both of the newly described species belong to an expanded Delma tincta group which displays a complex biogeographic pattern in northwestern Australia. An updated key to the Delma spp. of Western Australia is provided.
\end{abstract}

\section{INTRODUCTION}

There are currently 25 described species of pygopodid lizard known from Western Australia (Wilson and Swan 2003). Of these, Delma is the most speciose genus with ten species, five of which were described in a comprehensive taxonomic revision by Kluge (1974a). Since this revision, several additional species and subspecies have been recognized in Western Australia, including $D$. butleri Storr, 1987, D. haroldi Storr, 1987 and $D$. fraseri petersoni Shea, 1991. Shea (1991) advocated synonymy of $D$. haroldi and $D$. butleri and this view is supported in a recent phylogenetic study of pygopodid lizards by Jennings et al. (2003). These authors also elevated $D$. f. petersoni to full species status and advocated transfer of Aclys concinna Kluge, 1974 to Delma [as suggested also by Kluge (1976)]. Aplin and Smith (2001) highlighted further taxonomic complexity in the widespread $D$. australis Kluge, 1974 and in D. butleri, with preliminary investigations suggesting that both are composites.

Shea (1991) proposed a Delma tincta group to include $D$. tincta, $D$. borea and $D$. pax, based on their similar patterning, the usual presence of a single large temporal scale bordering each parietal scale, and their largely allopatric pattern of geographic distributions. The integrity of this grouping was strongly supported by Jennings et al.
(2003) analysis of DNA sequence variation among pygopodid lizards and by their combined morphological and molecular analysis. However, neither dataset was able to resolve the relationships among the three species.

Problems with the taxonomy of the Delma tincta group were noted by field herpetologists working in the Pilbara region in Western Australia. Application of a published key (Storr et al. 1990) resulted in some Pilbara specimens being identified as $D$. borea Kluge, 1974, which is otherwise known from the Kimberley region, Northern Territory, western Queensland (Kluge 1974; Shea 1987; Shea 1991) and northwestern South Australia (Ehmann 2005). Similar identification problems were apparent on the Cape Range Peninsula, where specimens initially identified as $D$. pax from the Exmouth region (Storr and Hanlon 1980) were subsequently transferred to $D$. tincta De Vis, 1888 (Storr et al. 1990).

This study presents molecular and morphological evidence for the recognition of two new species of Delma in northwestern Australia, both of which were previously confused with $D$. pax and/or $D$. tincta. The results further reinforce the opinion of Shea (1987) and others (e.g. Aplin and Smith 2001) that our knowledge of the taxonomy of the morphologically conservative genus Delma is far from complete. 


\section{METHODS}

\section{Morphological analysis}

This study is based on the examination of material held in the Western Australian Museum (WAM), Northern Territory Museum (NTM), Australian Museum (AM) and South Australian Museum

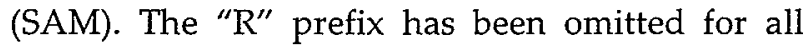
WAM, NTM, AM and SAM specimens and, unless otherwise indicated, specimen registration numbers refer to the herpetological collection of the Western Australian Museum. Sex of individuals was determined by dissection and inspection of gonads; some immature or poorly preserved individuals were left unsexed. Head scale terminology, methods of scale counting and morphometric measurements follow those used by Shea (1987), except that all scales between postnasal and circumocular granules are counted as loreals (after Storr et al. 1990). Bilateral loreal counts were averaged if different.

For the purpose of this study the following morphometrics data were taken with digital vernier calipers and plastic ruler: snout-vent length (SVL), tail length (Tail L), head depth immediately behind eye (Head D), head length from tip of snout to posterior margin of ear (Head L), head width between ear (Head $W$ ), hindlimb length from junction of limb flap with body to distal tip of flap (Hindlimb L), mouth length from tip of snout to oral rictus (Mouth $\mathrm{L}$ ), rostral depth between dorsal and ventral extremes of scale (Rostral D), rostral width between lateral extremes of scale (Rostral W), snout length from tip of snout to anterior margin of eye (Snout L) and eye width between anterior and posterior extremes of transparent cornea (Eye $W$ ). All measurements are reported in millimeters $(\mathrm{mm})$ and characters recorded from the right side only. Specimens preserved in a circular or twisted position were straightened on a flat surface when measured for snout-vent and tail length. Tails were not measured if they were recently broken or obviously regenerated, as suggested by a clear break in colouration or patterning. However, $x$-rays are necessary to reliably distinguishable original and fully regenerated tails and these were not taken during this study. Accordingly, tail measurements are not used in any taxonomic sense and statistical data are provided for descriptive purposes only.

For each species, the possibility of sexual dimorphism in body measurements and scale counts were explored by Analysis of Variance (ANOVA), following tests for normality and homogeneity of variance. Pairwise interspecific statistical comparisons were similarly conducted, using pooled-sex or single sex samples as appropriate. Contrasts are regarded as statistically significant if $p$ values were less than 0.05 .

Because significant sexual dimorphism was observed in SVL for most species, variation in the size and proportions of the head was further examined by Analysis of Covariance (ANCOVA). For each taxon, Head $L$ was first regressed against SVL for each sex and ANCOVA used to test for equality of the slopes and intercepts. All other dimensions were then regressed against Head $\mathrm{L}$ to test for differences in head proportions between the sexes.

Interspecific differences were explored by first preparing bivariate plots of all dimensions against SVL, separately for each sex. The head dimensions were then combined using Principal Component Analyses (PCA; based on covariance matrices) to produce a simplified representation of the morphometric variation. All analyses were performed on untransformed data after bivariate plots showed essentially linear patterns of relative growth among the various measures and no significant growth-related increase in variance in any dimension. Statistical analyses were performed with MINITAB Release 14.20 or GenStat Release 6.1.

All WAM specimens of $D$. borea and $D$. tincta collected subsequent to Kluge (1974) were assessed for three characters; supranasal scale division, midbody scale row count and the identity of the supralabial scale positioned beneath the eye to quantify the intraspecific variation and determine the effectiveness of these characters for identification. Due to their geographic proximity to the new species described herein, all specimens from the Western Australian Pilbara islands plus all available $D$. borea from the southern sector of the Northern Territory were also examined (see Appendix 1).

\section{Allozyme analysis}

Frozen liver or heart tissues for allozyme electrophoresis were obtained from the frozen tissue collections of the Western Australian and South Australian Museums for 12 specimens of typical D. pax, six specimens of the 'desert' morphotype, four specimens of the 'Cape Range' morphotype, and three specimens of each of $D$. tincta and $D$. borea from localities in northwestern Australia. We also included samples identified as $D$. butleri $(n=9)$ and $D$. haroldi $(n=4)$, drawn from across the geographic range of this sibling pair (or geographically variable taxon; Shea 1991). A total of 41 specimens were represented in the study (see Appendix 2 for voucher details). We used allozyme electrophoresis to test the hypothesis that each of the identified morphotypes within the Delma tincta group represents a distinct evolutionary species. The samples of $D$. butleri and $D$. haroldi were included as members of a second species group to provide a perspective on genetic diversity within the $D$. tincta group. 
Allozyme electrophoresis was carried out on cellulose acetate gels (Cellogel@) using the principles and procedures detailed in Richardson et al. (1986). The following enzymes or non-enzymatic proteins displayed sufficient activity and resolution to allow allozymic interpretation:- aconitase hydratase (ACON, EC 4.2.1.3), acid phosphatase (ACP, EC 3.1.3.2), aminoacylase (ACYC, EC 3.5.1.14), adenosine deaminase (ADA, EC 3.5.4.4), alcohol dehydrogenase (ADH, EC 1.1.1.1), carbonate dehydratase (CA, EC 4.2.1.1), diaphorase (DIA, EC 1.6.99), enolase (ENOL, EC 4.2.1.11), esterase (EST, EC 3.1.1), fructose-bisphosphatase (FDP, EC 3.1.3.11), fumarate hydratase (FUM, EC 4.2.1.2), glyceraldehyde-3-phospate dehydrogenase (GAPD, EC 1.2.1.12), guanine deaminase (GDA, EC 3.5.4.3), lactoylglutathione lyase (GLO, EC 4.4.1.5), aspartate aminotransferase (GOT, EC 2.6.1.1), glycerol-3-phosphate dehydrogenase (GPD, EC 1.1.1.8), glucose-6-phosphate isomerase (GPI, EC 5.3.1.9), guanylate kinase (GUK, EC 2.7.4.8), isocitrate dehydrogenase (IDH, EC 1.1.1.42), cytosol aminopeptidase (LAP, EC 3.4.11.1), L-lactate dehydrogenase (LDH, EC 1.1.1.27), malate dehydrogenase (MDH, EC 1.1.1.37), "malic" enzyme (ME, EC 1.1.1.40), mannose-6-phosphate isomerase (MPI, EC 5.3.1.8), nucleosidediphosphate kinase (NDPK, EC 2.7.4.6), dipeptidase (PEPA, EC 3.4.13), tripeptide aminopeptidase (PEPB, EC 3.4.11), proline dipeptidase (PEPD, EC 3.4.13), phosphogluconate dehydrogenase (6PGD, EC 1.1.1.44), phosphoglucomutase (PGM, EC 5.4.2.2), pyruvate kinase (PK, EC 2.7.1.40), superoxide dismutase (SOD, EC 1.15.1.1), L-iditol dehydrogenase (SRDH, EC 1.1.1.14) and triosephosphate isomerase (TPI, EC 5.3.1.1). The nomenclature used to refer to loci and allozymes follows Adams et al. (1987).

The allozyme data were analysed in several ways. In the first instance, Principal Co-ordinates Analysis (PCoA) was employed to assess the genetic affinities of individuals, independently of any a priori grouping based on morphology. Following an initial PCoA on all 41 specimens analysed, subsequent PCoAs were then undertaken on each of the three subsets of specimens which clustered together and comprised more than one morphotypic form. The rationale underlying this 'stepwise' use of multiple PCoAs to identify genetic groups from first principles, plus the methodological details involved, are presented in Smith and Adams (2006).

Having defined the major genetic groupings using PCoA, the phylogenetic relationships among these groups were explored by constructing a Neighbor Joining tree from pairwise Nei's genetic distances. This analysis was undertaken using the NEIGHBOR computer program contained with PHYLIP 3.5c (Felsenstein 1993), and the resultant tree drawn using TREEVIEW (Page 1996). A measure of the robustness of clades was obtained by bootstrapping the allele frequency data for 100 pseudoreplicates, using a BASIC program written by M. Adams.

A second measure of genetic divergence was obtained by calculating the percentage fixed differences (\% FDs) among groups. As argued by Richardson et al. (1986), the number of "fixed" or diagnostic differences between populations is more biologically relevant when determining species boundaries than are Nei $D$ values, which may be quite large even in the absence of any genuinely diagnostic loci.

\section{RESULTS}

\section{Morphological analysis}

Initial recognition of the potential new species emerged during a careful examination of all $D$. pax specimens and of $D$. borea specimens from the southern Kimberley in Western Australia and from southern Northern Territory. During this morphological survey, special attention was paid to the identity of the supralabial scale positioned beneath the eye and the detail and intensity of head patterning at various stages of maturity. Using these characters in combination, it was possible to detect subtle but consistent differences between three morphologically diagnosable geographic entities. These were: (i) true $D$. pax from the Pilbara with strong juvenile head pattern that fades early in ontogeny, (ii) a distinctive, inornate 'Cape Range' morphotype with similarities to each of $D$. pax and D. borea and (iii) a widespread 'desert' morphotype with a persistent well-developed head pattern. Each of these taxa appeared to be quite distinct from each of $D$. borea and $D$. tincta.

Before undertaking any morphometric comparisons, we examined the linear measurements and scale counts from each of the putative taxa and geographically proximate samples of $D$. borea and $D$. tincta for evidence of sexual dimorphism. Statistically significant sexual dimorphism was observed in each species but with contrasting expression in each (Tables 1 and 2).

In all putative taxa, females are significantly longer bodied (SVL) than males. In typical $D$. pax and the 'desert' morphotype the mean SVL of females is $109 \%$ and $112 \%$ larger than that of conspecific males (Table 1). This value is slightly lower in D. borea (107\%). The small sample of the 'Cape Range' morphotype gives an estimate of dimorphism of $112 \%$. These observations are consistent with Kluge's (1974: 34) observation for pygopodids that "the female of a given species almost always attains a larger size than the male."

In each of $D$. pax, the 'desert' morphotype and $D$. 
Table 1 Summary of mensural and meristic data gathered in this study, presented separately for each sex. The 'desert' and 'Cape Range' morphotypes are listed in this and all subsequent tables as $D$. desmosa and $D$. tealei, respectively, reflecting the ultimate taxonomic arrangement. Also shown are data for the redefined $D$. pax and for geographically proximate samples of $D$. borea and $D$. tincta. Values are mean \pm one standard deviation, range and sample size (n).

\begin{tabular}{|c|c|c|c|c|c|c|}
\hline & & D. tealei & D. desmosa & D. $p a x$ & $D$. borea & D. tincta \\
\hline \multirow[t]{2}{*}{ SVL } & $\delta$ & $\begin{array}{c}73.7 \pm 1.49 \\
70-77 \\
(4)\end{array}$ & $\begin{array}{c}70.0 \pm 1.47 \\
60-80 \\
(24)\end{array}$ & $\begin{array}{c}74.1 \pm 1.42 \\
55-93 \\
(42)\end{array}$ & $\begin{array}{c}70.0 \pm 1.10 \\
54-88 \\
(42)\end{array}$ & $\begin{array}{c}66.6 \pm 1.72 \\
58-72 \\
(9)\end{array}$ \\
\hline & $q$ & $\begin{array}{c}82.2 \pm 2.56 \\
77-88 \\
(4)\end{array}$ & $\begin{array}{c}78.4 \pm 2.53 \\
56-90 \\
(15)\end{array}$ & $\begin{array}{c}81.0 \pm 1.46 \\
58-98 \\
(39)\end{array}$ & $\begin{array}{c}74.8 \pm 1.18 \\
54-95 \\
(50)\end{array}$ & $\begin{array}{c}79.4 \pm 4.62 \\
66-92 \\
(5)\end{array}$ \\
\hline \multirow[t]{2}{*}{ Tail L } & $\delta$ & $\begin{array}{c}146.3 \pm 33.0 \\
107-212 \\
(3)\end{array}$ & $\begin{array}{c}198.2 \pm 10.7 \\
85-275 \\
(24)\end{array}$ & $\begin{array}{c}184.4 \pm 7.67 \\
109-271 \\
(32)\end{array}$ & $\begin{array}{c}172.9 \pm 6.86 \\
57-240 \\
(35)\end{array}$ & $\begin{array}{c}189.3 \pm 17.61 \\
102-263 \\
(9)\end{array}$ \\
\hline & $q$ & $\begin{array}{c}142.2 \pm 29.7 \\
87-210 \\
(4)\end{array}$ & $\begin{array}{c}187.5 \pm 13.0 \\
80-257 \\
(14)\end{array}$ & $\begin{array}{c}198.5 \pm 6.31 \\
117-257 \\
(33)\end{array}$ & $\begin{array}{c}176.5 \pm 9.21 \\
53-259 \\
(42)\end{array}$ & $\begin{array}{c}228.6 \pm 11.87 \\
200-260 \\
(5)\end{array}$ \\
\hline \multirow[t]{2}{*}{ Ventrals } & $\delta$ & $\begin{array}{c}50.5 \pm 0.5 \\
50-52 \\
(4)\end{array}$ & $\begin{array}{c}51.8 \pm 0.30 \\
48-56 \\
(24)\end{array}$ & $\begin{array}{c}54.2 \pm 0.30 \\
50-58 \\
(43)\end{array}$ & $\begin{array}{c}53.7 \pm 0.46 \\
47-62 \\
(42)\end{array}$ & $\begin{array}{c}48.7 \pm 0.78 \\
44-52 \\
(9)\end{array}$ \\
\hline & 우 & $\begin{array}{c}51.5 \pm 0.5 \\
50-52 \\
(4)\end{array}$ & $\begin{array}{c}52.9 \pm 0.45 \\
50-58 \\
(15)\end{array}$ & $\begin{array}{c}56.0 \pm 0.32 \\
52-60 \\
(39)\end{array}$ & $\begin{array}{c}54.3 \pm 0.34 \\
50-58 \\
(50)\end{array}$ & $\begin{array}{c}52.4 \pm 0.68 \\
50-58 \\
(5)\end{array}$ \\
\hline \multirow[t]{2}{*}{ Head L } & $\delta$ & $\begin{array}{c}8.50 \pm 0.09 \\
8.36-8.77 \\
(4)\end{array}$ & $\begin{array}{c}8.04 \pm 0.13 \\
7.08-9.28 \\
(24)\end{array}$ & $\begin{array}{c}8.51 \pm 0.10 \\
6.96-9.88 \\
(43)\end{array}$ & $\begin{array}{c}8.13 \pm 0.09 \\
6.79-9.39 \\
(42)\end{array}$ & $\begin{array}{c}7.58 \pm 0.16 \\
6.96-8.22 \\
(9)\end{array}$ \\
\hline & $q$ & $\begin{array}{c}8.81 \pm 0.27 \\
8.18-9.39 \\
(4)\end{array}$ & $\begin{array}{c}8.52 \pm 0.16 \\
7.21-9.65 \\
(15)\end{array}$ & $\begin{array}{c}8.72 \pm 0.10 \\
7.45-9.78 \\
(39)\end{array}$ & $\begin{array}{c}8.34 \pm 0.10 \\
6.68-9.89 \\
(50)\end{array}$ & $\begin{array}{c}8.20 \pm 0.35 \\
7.16-9.02 \\
\text { (5) }\end{array}$ \\
\hline \multirow[t]{2}{*}{ Head W } & $\sigma^{\pi}$ & $\begin{array}{c}5.55 \pm 0.09 \\
5.35-5.75 \\
(4)\end{array}$ & $\begin{array}{c}4.76 \pm 0.08 \\
3.91-5.54 \\
(24)\end{array}$ & $\begin{array}{c}5.11 \pm 0.08 \\
3.96-6.48 \\
(43)\end{array}$ & $\begin{array}{c}4.82 \pm 0.08 \\
3.91-5.99 \\
(42)\end{array}$ & $\begin{array}{c}4.52 \pm 0.16 \\
3.88-5.24 \\
(9)\end{array}$ \\
\hline & $q$ & $\begin{array}{c}5.53 \pm 0.23 \\
5.11-6.16 \\
(4)\end{array}$ & $\begin{array}{c}5.11 \pm 0.15 \\
3.85-6.06 \\
(15)\end{array}$ & $\begin{array}{c}5.34 \pm 0.10 \\
3.71-6.73 \\
(39)\end{array}$ & $\begin{array}{c}5.01 \pm 0.07 \\
3.69-6.06 \\
(50)\end{array}$ & $\begin{array}{c}4.77 \pm 0.32 \\
3.97-5.59 \\
(5)\end{array}$ \\
\hline \multirow[t]{2}{*}{ Head D } & $\sigma$ & $\begin{array}{c}4.49 \pm 0.27 \\
3.85-5.04 \\
(4)\end{array}$ & $\begin{array}{c}4.39 \pm 0.08 \\
3.60-5.13 \\
(24)\end{array}$ & $\begin{array}{c}4.52 \pm 0.07 \\
3.51-5.97 \\
(43)\end{array}$ & $\begin{array}{c}3.91 \pm 0.07 \\
3.16-5.04 \\
(42)\end{array}$ & $\begin{array}{c}3.79 \pm 0.10 \\
3.35-4.39 \\
(9)\end{array}$ \\
\hline & q & $\begin{array}{c}4.44 \pm 0.13 \\
4.11-4.73 \\
(4)\end{array}$ & $\begin{array}{c}4.70 \pm 0.15 \\
3.61-5.65 \\
(14)\end{array}$ & $\begin{array}{c}4.68 \pm 0.12 \\
3.33-6.25 \\
(39)\end{array}$ & $\begin{array}{c}4.07 \pm 0.07 \\
3.06-5.45 \\
(49)\end{array}$ & $\begin{array}{c}3.94 \pm 0.22 \\
3.44-4.52 \\
(4)\end{array}$ \\
\hline \multirow[t]{2}{*}{ Mouth L } & $\delta^{\pi}$ & $\begin{array}{c}5.89 \pm 0.14 \\
5.51-6.18 \\
(4)\end{array}$ & $\begin{array}{c}5.83 \pm 0.12 \\
4.88-6.84 \\
(24)\end{array}$ & $\begin{array}{c}6.29 \pm 0.12 \\
5.24-8.40 \\
(43)\end{array}$ & $\begin{array}{c}5.65 \pm 0.08 \\
4.63-6.79 \\
(42)\end{array}$ & $\begin{array}{c}6.23 \pm 0.21 \\
4.87-6.99 \\
(9)\end{array}$ \\
\hline & $q$ & $\begin{array}{c}5.85 \pm 0.11 \\
5.59-6.13 \\
(4)\end{array}$ & $\begin{array}{c}6.19 \pm 0.14 \\
4.99-6.93 \\
(15)\end{array}$ & $\begin{array}{c}6.49 \pm 0.10 \\
5.02-7.99 \\
(39)\end{array}$ & $\begin{array}{c}5.80 \pm 0.07 \\
4.51-6.82 \\
(50)\end{array}$ & $\begin{array}{c}6.71 \pm 0.34 \\
5.76-7.89 \\
(5)\end{array}$ \\
\hline
\end{tabular}

tincta the number of enlarged ventral scales is significantly higher in females than males (Table 2), with mean ventral scale counts in females being 1.8 , 1.1 and 3.7 (scales) greater than the conspecific male values, respectively (Table 1 ). In contrast, $D$. borea and the 'Cape Range' morphotype do not show significant sexual dimorphism in this feature, although in each case the mean value for females is 
Table 1 (cont.)

\begin{tabular}{|c|c|c|c|c|c|c|}
\hline & & D. tealei & D. desmosa & D. pax & D. borea & D. tincta \\
\hline \multirow[t]{2}{*}{ Snout L } & 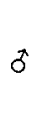 & $\begin{array}{c}3.53 \pm 0.11 \\
3.32-3.78 \\
(4)\end{array}$ & $\begin{array}{c}3.19 \pm 0.06 \\
2.33-3.86 \\
(24)\end{array}$ & $\begin{array}{c}3.46 \pm 0.05 \\
2.74-4.76 \\
(43)\end{array}$ & $\begin{array}{c}3.28 \pm 0.04 \\
2.69-4.07 \\
(42)\end{array}$ & $\begin{array}{c}3.06 \pm 0.10 \\
2.76-3.76 \\
(9)\end{array}$ \\
\hline & q & $\begin{array}{c}3.51 \pm 0.11 \\
3.35-3.84 \\
(4)\end{array}$ & $\begin{array}{c}3.39 \pm 0.09 \\
2.61-3.93 \\
(15)\end{array}$ & $\begin{array}{c}3.52 \pm 0.05 \\
2.96-4.29 \\
(39)\end{array}$ & $\begin{array}{c}3.40 \pm 0.04 \\
2.63-4.09 \\
(50)\end{array}$ & $\begin{array}{c}3.39 \pm 0.21 \\
2.76-4.00 \\
(5)\end{array}$ \\
\hline \multirow[t]{2}{*}{ Rostral W } & $\hat{o}$ & $\begin{array}{c}1.88 \pm 0.05 \\
1.77-2.01 \\
(4)\end{array}$ & $\begin{array}{c}1.62 \pm 0.04 \\
0.93-1.88 \\
(24)\end{array}$ & $\begin{array}{c}1.66 \pm 0.02 \\
1.26-2.06 \\
(43)\end{array}$ & $\begin{array}{c}1.54 \pm 0.02 \\
1.23-1.84 \\
(42)\end{array}$ & $\begin{array}{c}1.44 \pm 0.03 \\
1.28-1.66 \\
(9)\end{array}$ \\
\hline & $q$ & $\begin{array}{c}1.85 \pm 0.08 \\
1.63-2.06 \\
(4)\end{array}$ & $\begin{array}{c}1.79 \pm 0.04 \\
1.51-2.27 \\
(15)\end{array}$ & $\begin{array}{c}1.78 \pm 0.03 \\
1.40-2.19 \\
(38)\end{array}$ & $\begin{array}{c}1.58 \pm 0.02 \\
1.17-1.98 \\
(50)\end{array}$ & $\begin{array}{c}1.61 \pm 0.06 \\
1.48-1.87 \\
(5)\end{array}$ \\
\hline \multirow[t]{2}{*}{ Rostral D } & $\sigma$ & $\begin{array}{c}0.92 \pm 0.07 \\
0.76-1.10 \\
(4)\end{array}$ & $\begin{array}{c}0.95 \pm 0.02 \\
0.52-1.24 \\
(24)\end{array}$ & $\begin{array}{c}1.03 \pm 0.02 \\
0.81-1.25 \\
(43)\end{array}$ & $\begin{array}{c}0.87 \pm 0.01 \\
0.71-1.16 \\
(42)\end{array}$ & $\begin{array}{c}1.00 \pm 0.03 \\
0.81-1.14 \\
(9)\end{array}$ \\
\hline & $q$ & $\begin{array}{c}1.09 \pm 0.06 \\
0.93-1.25 \\
(4)\end{array}$ & $\begin{array}{c}1.00 \pm 0.03 \\
0.67-1.18 \\
(15)\end{array}$ & $\begin{array}{c}1.06 \pm 0.01 \\
0.84-1.33 \\
(38)\end{array}$ & $\begin{array}{c}0.89 \pm 0.01 \\
0.64-1.21 \\
(50)\end{array}$ & $\begin{array}{c}0.98 \pm 0.06 \\
0.73-1.06 \\
(5)\end{array}$ \\
\hline \multirow[t]{2}{*}{ Eye W } & $0^{\pi}$ & $\begin{array}{c}1.73 \pm 0.13 \\
1.48-2.04 \\
(4)\end{array}$ & $\begin{array}{c}1.46 \pm 0.04 \\
0.83-1.74 \\
(24)\end{array}$ & $\begin{array}{c}1.56 \pm 0.02 \\
1.23-1.84 \\
(42)\end{array}$ & $\begin{array}{c}1.50 \pm 0.02 \\
1.34-1.79 \\
(42)\end{array}$ & $\begin{array}{c}1.55 \pm 0.07 \\
1.16-1.88 \\
(9)\end{array}$ \\
\hline & $q$ & $\begin{array}{c}1.97 \pm 0.14 \\
1.56-2.13 \\
(4)\end{array}$ & $\begin{array}{c}1.54 \pm 0.04 \\
1.16-1.79 \\
(15)\end{array}$ & $\begin{array}{c}1.56 \pm 0.02 \\
1.28-1.93 \\
(39)\end{array}$ & $\begin{array}{c}1.49 \pm 0.02 \\
1.19-1.81 \\
(50)\end{array}$ & $\begin{array}{c}1.60 \pm 0.08 \\
1.39-1.79 \\
(5)\end{array}$ \\
\hline \multirow[t]{2}{*}{ Hindlimb L } & $\delta$ & $\begin{array}{c}3.20 \pm 0.21 \\
2.91-3.81 \\
(4)\end{array}$ & $\begin{array}{c}3.63 \pm 0.10 \\
2.59-4.42 \\
(24)\end{array}$ & $\begin{array}{c}3.60 \pm 0.09 \\
1.70-4.92 \\
(43)\end{array}$ & $\begin{array}{c}2.61 \pm 0.05 \\
1.73-3.43 \\
(41)\end{array}$ & $\begin{array}{c}2.63 \pm 0.14 \\
1.73-3.16 \\
(9)\end{array}$ \\
\hline & $q$ & $\begin{array}{c}2.89 \pm 0.27 \\
2.08-3.31 \\
(4)\end{array}$ & $\begin{array}{c}2.89 \pm 0.13 \\
1.95-3.53 \\
(15)\end{array}$ & $\begin{array}{c}2.62 \pm 0.06 \\
1.95-3.80 \\
(39)\end{array}$ & $\begin{array}{c}2.10 \pm 0.04 \\
1.46-2.95 \\
(49)\end{array}$ & $\begin{array}{c}2.38 \pm 0.16 \\
1.99-2.95 \\
(5)\end{array}$ \\
\hline \multirow[t]{2}{*}{ Loreals } & $\delta$ & $\begin{array}{c}7.25 \pm 0.66 \\
6-9 \\
(4)\end{array}$ & $\begin{array}{c}6.85 \pm 0.22 \\
5-9 \\
(24)\end{array}$ & $\begin{array}{c}7.37 \pm 0.18 \\
5-10 \\
(43)\end{array}$ & $\begin{array}{c}7.50 \pm 0.19 \\
4-9 \\
(40)\end{array}$ & $\begin{array}{c}4.96 \pm 0.20 \\
4-6 \\
(9)\end{array}$ \\
\hline & $q$ & $\begin{array}{c}6.25 \pm 0.48 \\
5-7 \\
(4)\end{array}$ & $\begin{array}{c}6.87 \pm 0.29 \\
5-8 \\
(15)\end{array}$ & $\begin{array}{c}7.54 \pm 0.19 \\
5-10 \\
(39)\end{array}$ & $\begin{array}{c}7.24 \pm 0.19 \\
4-11 \\
(50)\end{array}$ & $\begin{array}{c}5.30 \pm 0.46 \\
4.5-7 \\
(5)\end{array}$ \\
\hline \multirow[t]{2}{*}{$\begin{array}{l}\text { Hindlimb } \\
\text { scales }\end{array}$} & 0 & $\begin{array}{c}8 \pm 0.00 \\
8 \\
(4)\end{array}$ & $\begin{array}{c}8 \pm 0.00 \\
8 \\
(24)\end{array}$ & $\begin{array}{c}8.51 \pm 0.88 \\
8-10 \\
(43)\end{array}$ & $\begin{array}{c}8.00 \pm 1.25 \\
5-10 \\
(41)\end{array}$ & $\begin{array}{c}5 \pm 0.00 \\
5 \\
(9)\end{array}$ \\
\hline & q & $\begin{array}{c}8 \pm 0.00 \\
8 \\
(4)\end{array}$ & $\begin{array}{c}8 \pm 0.00 \\
8 \\
(15)\end{array}$ & $\begin{array}{c}8.56 \pm 0.91 \\
8-10 \\
(39)\end{array}$ & $\begin{array}{c}7.66 \pm 1.17 \\
5-9 \\
(50)\end{array}$ & $\begin{array}{c}5 \pm 0.00 \\
5 \\
(5)\end{array}$ \\
\hline
\end{tabular}

higher than that for males. Kluge (1974) reported significant sexual dimorphism in mean ventral counts (always greater in females than males) in four species of Delma [D. australis, D. impar (Fischer, 1882), D. nasuta Kluge, 1974, and $D$. tincta], with means differing by 3-5 scales in each case. Species that Kluge (1974) found to be nondimorphic in this attribute include $D$. borea, $D$. fraseri Gray, 1831, D. grayii Smith, 1849, D. inornata Kluge, 1974, D. molleri Lütken, 1863 and $D$. plebeia De Vis, 1888. Kluge's (1974) samples of $D$. nasuta and $D$. inornata were both composites as they both included specimens subsequently referred to $D$. butleri (Storr 1987; Shea 1991).

Sexual dimorphism in hindlimb length is expressed in each of D. pax, the 'desert' 
Table 2 Statistical analysis (ANOVA) of intraspecific sexual dimorphism in selected mensural and meristic characters for each of $D$. tealei, D. desmosa, D. pax, D. borea, and D. tincta.

\begin{tabular}{|c|c|c|c|c|c|}
\hline & D. tealei & D. desmosa & D. pax & D. borea & D. tincta \\
\hline SVL & $\begin{array}{l}F=8.218 \\
\text { d.f. }=1,7 \\
P=0.029\end{array}$ & $\begin{array}{l}F=9.600 \\
\text { d.f. }=1,38 \\
P=0.004\end{array}$ & $\begin{array}{l}F=11.380 \\
\text { d.f. }=1,80 \\
P=0.001\end{array}$ & $\begin{array}{l}F=8.311 \\
\text { d.f. }=1,91 \\
P=0.005\end{array}$ & $\begin{array}{l}F=9.753 \\
\text { d.f. }=1,13 \\
P=0.009\end{array}$ \\
\hline Tail L & $\begin{array}{l}F=0.008 \\
\text { d.f. }=1,6 \\
P=0.931\end{array}$ & $\begin{array}{l}F=0.387 \\
\text { d.f. }=1,37 \\
P=0.538\end{array}$ & $\begin{array}{l}F=2.027 \\
\text { d.f. }=1,64 \\
P=0.160\end{array}$ & $\begin{array}{l}F=0.093 \\
\text { d.f. }=1,76 \\
P=0.761\end{array}$ & $\begin{array}{l}F=2.364 \\
\text { d.f. }=1,13 \\
P=0.150\end{array}$ \\
\hline Ventrals & $\begin{array}{l}F=2.000 \\
\text { d.f. }=1,7 \\
P=0.207\end{array}$ & $\begin{array}{l}F=5.231 \\
\text { d.f. }=1,38 \\
P=0.028\end{array}$ & $\begin{array}{l}F=17.595 \\
\text { d.f. }=1,81 \\
P<0.001\end{array}$ & $\begin{array}{l}F=1.175 \\
\text { d.f. }=1,91 \\
P=0.281\end{array}$ & $\begin{array}{l}F=10.105 \\
\text { d.f. }=1,13 \\
P=0.008\end{array}$ \\
\hline Head L & $\begin{array}{l}F=1.108 \\
\text { d.f. }=1,7 \\
P=0.330\end{array}$ & $\begin{array}{l}F=4.933 \\
\text { d.f. }=1,38 \\
P=0.033\end{array}$ & $\begin{array}{l}F=1.995 \\
\text { d.f. }=1,81 \\
P=0.162\end{array}$ & $\begin{array}{l}F=2.274 \\
\text { d.f. }=1,91 \\
P=0.135\end{array}$ & $\begin{array}{l}F=3.407 \\
\text { d.f. }=1,13 \\
P=0.090\end{array}$ \\
\hline Head W & $\begin{array}{l}F=0.008 \\
\text { d.f. }=1,7 \\
P=0.931\end{array}$ & $\begin{array}{l}F=4.464 \\
\text { d.f. }=1,38 \\
P=0.041\end{array}$ & $\begin{array}{l}F=2.967 \\
\text { d.f. }=1,81 \\
P=0.089\end{array}$ & $\begin{array}{l}F=2.839 \\
\text { d.f. }=1,91 \\
P=0.096\end{array}$ & $\begin{array}{l}F=0.576 \\
\text { d.f. }=1,13 \\
P=0.463\end{array}$ \\
\hline Head D & $\begin{array}{l}F=0.0296 \\
\text { d.f. }=1,7 \\
P=0.869\end{array}$ & $\begin{array}{l}F=3.741 \\
\text { d.f. }=1,37 \\
P=0.061\end{array}$ & $\begin{array}{l}F=1.246 \\
\text { d.f. }=1,81 \\
P=0.268\end{array}$ & $\begin{array}{l}F=2.591 \\
\text { d.f. }=1,90 \\
P=0.111\end{array}$ & $\begin{array}{l}F=0.498 \\
\text { d.f. }=1,12 \\
P=0.495\end{array}$ \\
\hline Mouth L & $\begin{array}{l}F=0.047 \\
\text { d.f. }=1,7 \\
P=0.835\end{array}$ & $\begin{array}{l}F=3.296 \\
\text { d.f. }=1,38 \\
P=0.078\end{array}$ & $\begin{array}{l}F=1.508 \\
\text { d.f. }=1,81 \\
P=0.223\end{array}$ & $\begin{array}{l}F=1.706 \\
\text { d.f. }=1,91 \\
P=0.195\end{array}$ & $\begin{array}{l}F=1.543 \\
\text { d.f. }=1,13 \\
P=0.238\end{array}$ \\
\hline Snout L & $\begin{array}{l}F=0.016 \\
\text { d.f. }=1,7 \\
P=0.904\end{array}$ & $\begin{array}{l}F=3.044 \\
\text { d.f. }=1,38 \\
P=0.089\end{array}$ & $\begin{array}{l}F=0.536 \\
\text { d.f. }=1,81 \\
P=0.466\end{array}$ & $\begin{array}{l}F=2.955 \\
\text { d.f. }=1,91 \\
P=0.089\end{array}$ & $\begin{array}{l}F=2.513 \\
\text { d.f. }=1,13 \\
P=0.139\end{array}$ \\
\hline Rostral W & $\begin{array}{l}F=0.084 \\
\text { d.f. }=1,7 \\
P=0.781\end{array}$ & $\begin{array}{l}F=5.659 \\
\text { d.f. }=1,38 \\
P=0.023\end{array}$ & $\begin{array}{l}F=7.498 \\
\text { d.f. }=1,80 \\
P=0.008\end{array}$ & $\begin{array}{l}F=1.582 \\
\text { d.f. }=1,91 \\
P=0.212\end{array}$ & $\begin{array}{l}F=6.231 \\
\text { d.f. }=1,13 \\
P=0.028\end{array}$ \\
\hline Rostral D & $\begin{array}{l}F=2.894 \\
\text { d.f. }=1,7 \\
P=0.140\end{array}$ & $\begin{array}{l}F=1.354 \\
\text { d.f. }=1,38 \\
P=0.252\end{array}$ & $\begin{array}{l}F=1.320 \\
\text { d.f. }=1,80 \\
P=0.254\end{array}$ & $\begin{array}{l}F=0.837 \\
\text { d.f. }=1,91 \\
P=0.363\end{array}$ & $\begin{array}{l}F=0.101 \\
\text { d.f. }=1,13 \\
P=0.756\end{array}$ \\
\hline Eye W & $\begin{array}{l}F=1.555 \\
\text { d.f. }=1,7 \\
P=0.259\end{array}$ & $\begin{array}{l}F=1.622 \\
\text { d.f. }=1,38 \\
P=0.211\end{array}$ & $\begin{array}{l}F=0.001 \\
\text { d.f. }=1,80 \\
P=0.979\end{array}$ & $\begin{array}{l}F=0.149 \\
\text { d.f. }=1,91 \\
P=0.700\end{array}$ & $\begin{array}{l}F=0.208 \\
\text { d.f. }=1,13 \\
P=0.657\end{array}$ \\
\hline Hindlimb L & $\begin{array}{l}F=0.839 \\
\text { d.f. }=1,7 \\
P=0.395\end{array}$ & $\begin{array}{l}F=18.702 \\
\text { d.f. }=1,38 \\
P<0.001\end{array}$ & $\begin{array}{l}F=65.496 \\
\text { d.f. }=1,81 \\
P<0.001\end{array}$ & $\begin{array}{l}F=49.009 \\
\text { d.f. }=1,89 \\
P<0.001\end{array}$ & $\begin{array}{l}F=1.103 \\
\text { d.f. }=1,13 \\
P=0.314\end{array}$ \\
\hline Loreals & $\begin{array}{l}F=1.500 \\
\text { d.f. }=1,7 \\
P=0.267\end{array}$ & $\begin{array}{l}F=0.001 \\
\text { d.f. }=1,38 \\
P=0.973\end{array}$ & $\begin{array}{l}F=0.405 \\
\text { d.f. }=1,81 \\
P=0.526\end{array}$ & $\begin{array}{l}F=0.887 \\
\text { d.f. }=1,89 \\
P=0.349\end{array}$ & $\begin{array}{l}F=0.641 \\
\text { d.f. }=1,13 \\
P=0.439\end{array}$ \\
\hline
\end{tabular}

morphotype and $D$. borea, with males having longer hindlimb flaps in each taxon (Table 1). Bivariate plots of this measurement against SVL for each of these taxa (Figure $1 \mathrm{~A}-\mathrm{C}$ ) show that variance in hindlimb length is low at early growth stages (low SVL) and that sexual dimorphism emerges through life as a result of more rapid growth of the hindlimb, relative to SVL, in males than females. The different relative growth trajectory of each sex is confirmed by results of ANCOVA for each of $D$. pax and D. borea (Table 3). Results for the 'desert' morphotype are not statistically significant but this may be due to the lack of smaller females in the sample. Too few individuals of the 'Cape Range' morphotype were available and too few specimens of $D$. tincta were examined to determine the extent of hindlimb sexual dimorphism in each of these taxa. Somewhat surprisingly, the number of hindlimb scales is not sexually dimorphic in any of the studied species (Table 1). Kluge (1974) did not 


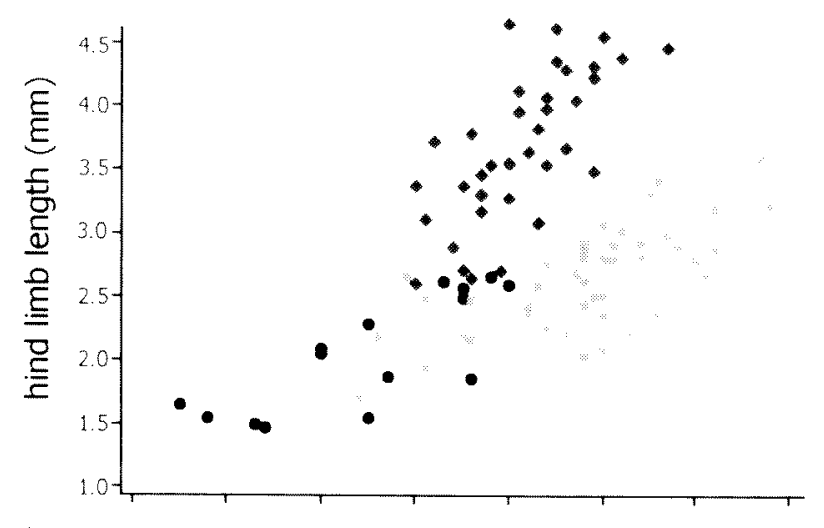

A
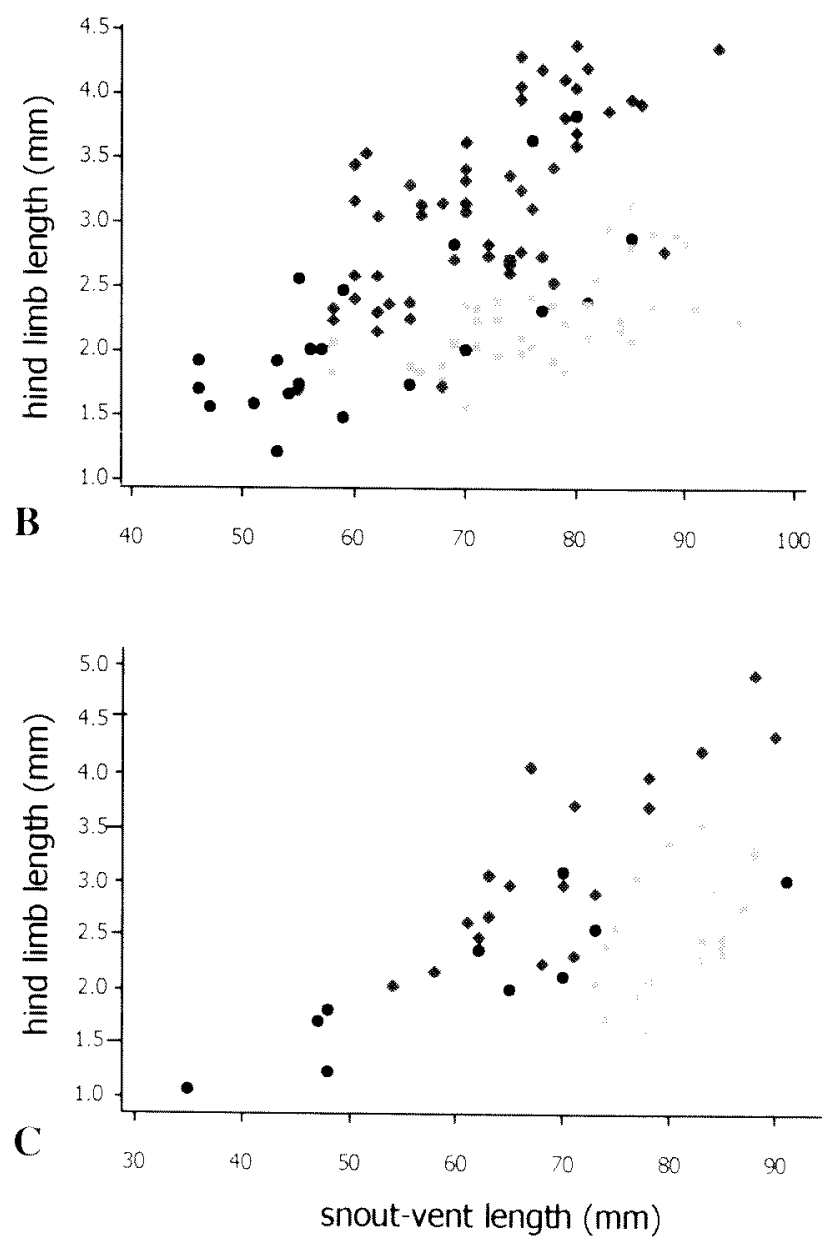

Figure 1 Bivariate plots of Hindlimb $L$ against SVL for each of D. pax (A); D. borea (B) and the 'desert' morphotype (C). In each plot, males (diamonds) are distinguished from females (squares) and unsexed individuals (circles). The plots demonstrate that male-biased sexual dimorphism in hindlimb length in each species arises through more rapid growth of this appendage in males than in females. present hindlimb lengths but did report a lack of sexual dimorphism in hindlimb scale counts in all Delma species.

For head dimensions, only a few statistically significant or near significant contrasts (Table 2) are observed between the sexes in each of $D$. pax (Head W, Rostral W), D. borea (Head W, Snout L), with mean values for females exceeding those of males in all cases. In contrast, the 'desert' morphotype shows female-biased sexual dimorphism in most head dimensions. Examination of bivariate plots of each head dimension against SVL (Figure 2A-C) indicate a clear lack of sexual dimorphism in $D$. borea, with no differences in the slopes or intercepts of regression lines, but a more complex situation in each of D. pax and the 'desert' morphotype. In these taxa, regression slopes are slightly higher in males than females, indicating a more rapid growth of the head relative to $S V L$ in males than in females. However, for both taxa ANCOVA-s were not significant for any head dimension against SVL (Table 3). Bivariate plots of all other head dimensions against Head $L$ for each taxon failed to reveal any sexual dimorphism in head proportions (Figure 2D-F for Head $W$ against Head $L$ ) and this was also confirmed by non-significant results from ANCOVA (not shown). Males in each of these species of Delma thus develop a slightly larger head than females through life, but without any obvious proportional changes.

No sexual dimorphism was observed in loreal counts. This finding is consistent with that of Kluge (1974) for other Delma species and for pygopodids generally. Uniquely among pygopodids, Lialis burtonis Gray, 1835 is sexually dimorphic in the number of supralabial scales (Kluge 1974: 132).

Table 4 gives a summary of pairwise statistical comparisons among $D$. pax, D. desmosa and $D$. borea for various measurements and scale counts, with separate comparisons for each sex. Comments on statistically significant contrasts are provided under the individual species accounts.

For head dimensions, interspecific contrasts were examined separately for each sex by bivariate plots and then by PCA (results not shown). No clear interspecific differences were found. Instead, the head appears to be remarkably conservative in proportions among all of the species examined.

\section{Allozymo analysis}

We were able to score a total of 43 presumptive allozyme loci. Nine loci (Est1, Gapd, Idh1, Lap, $L d h 1, L d h 2, M d h, P k$, and $T p l$ ) were invariant and hence uninformative for assessing genetic relationships among individuals. Appendix 2 presents the allozyme profiles of the 41 specimens examined at the 34 variable loci.

The initial PCOA on all specimens revealed the presence of four discrete clusters, labeled A-D on 


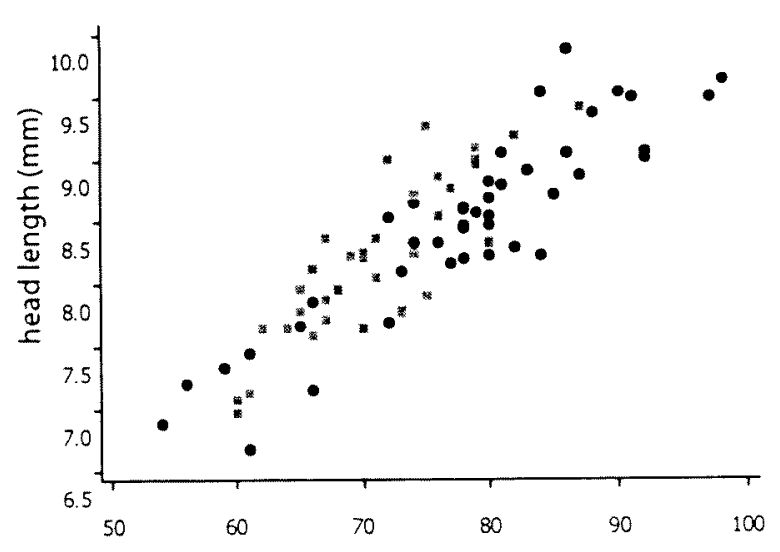

A

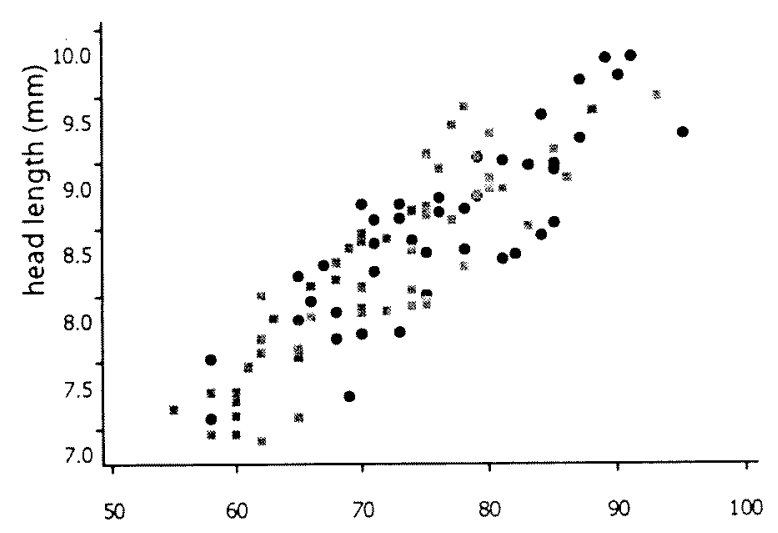

B

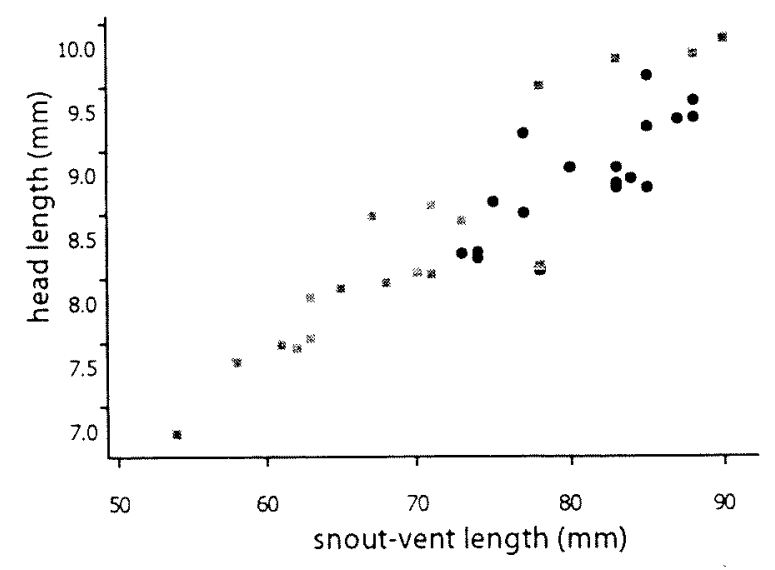

$\mathrm{C}$

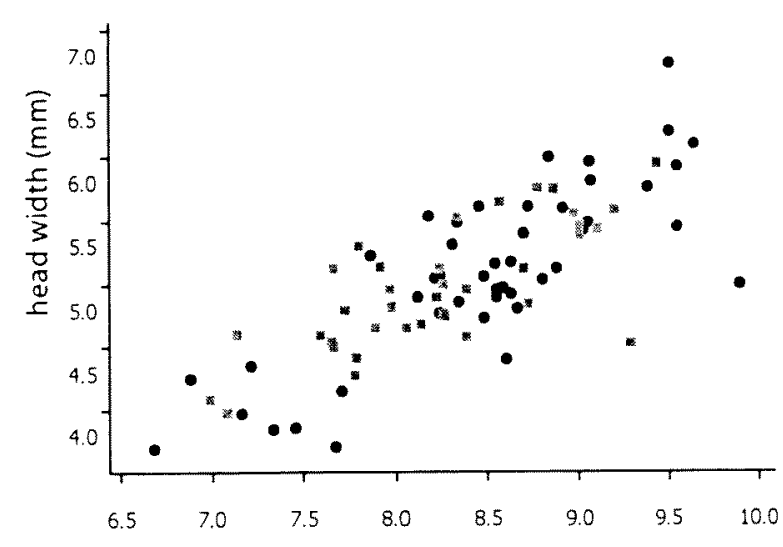

D

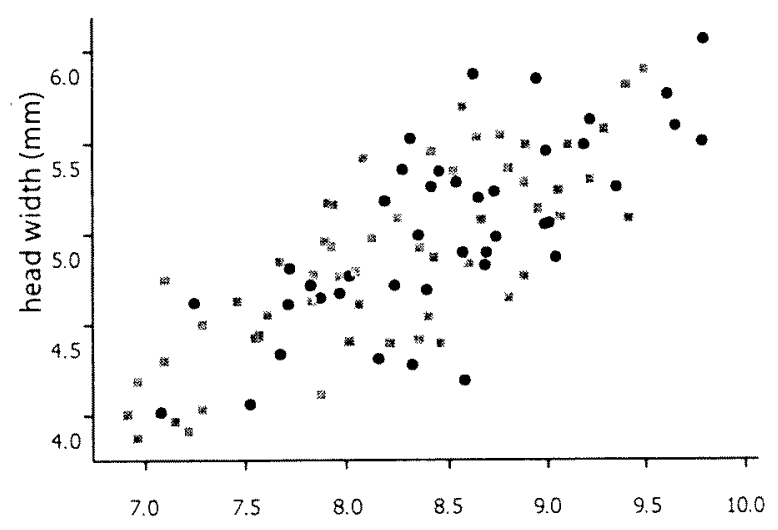

E

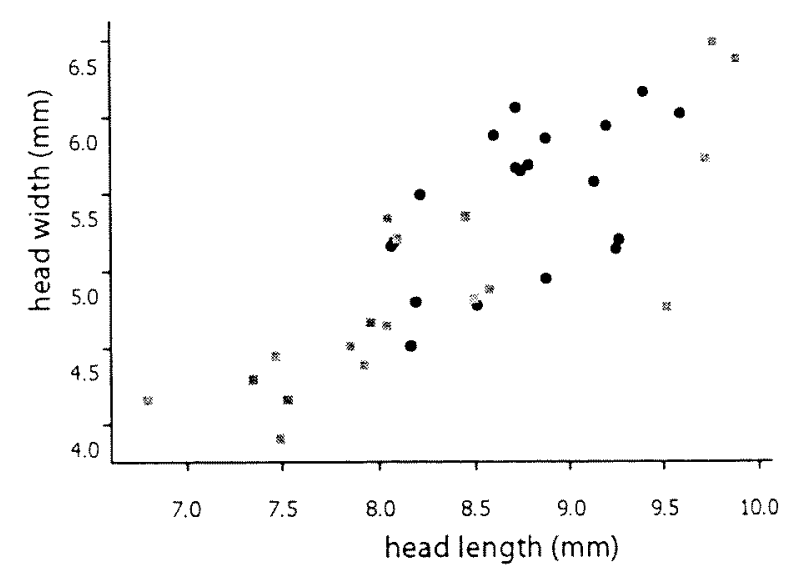

F

Figure 2 Bivariate plots of Head L against SVL and Head W against Head L for each of D. pax (A, D); D. borea (B, E) and the 'desert' morphotype (C, F). In each plot, males (squares) are distinguished from females (circles). The plots demonstrate slightly more rapid growth of the head relative to SVL in each of $D$. pax and the 'desert' morphotype, and a lack of differentiation between the sexes in head proportions.

Figure 3. As shown, only group D comprised specimens of a single a priori taxon (i.e. D. tincta). All other groups were composites: group A comprised specimens displaying either the pax or 'desert' morphotype, group B contained specimens referable to the 'Cape Range' morphotype or $D$. borea, and group $C$ was a mix of both $D$. butleri and $D$. haroldi.

In order to determine whether all taxa were independently diagnosable by their allozyme profiles, a second round of PCoAs was undertaken on individuals within each of the composite groups $A, B$, and C (Figure 4). Unequivocal discrimination was indeed obtained between $D$. pax and the 'desert' morphotype (Figure 4A) and between $D$. borea and the 'Cape Range' morphotype (Figure $4 \mathrm{~B})$. The outcome was more complex for group C, since while haroldi was distinguishable from 
Table 3 Statistical analysis (ANCOVA) of intraspecific sexual dimorphism for hindlimb and selected head dimensions for each of $D$. borea, $D$. desmosa and $D$. pax. Regression values are slope (a) \pm s.e. and intercept (i). All regressions are highly significant and all contrasts passed tests of homogeneity of variance.

\begin{tabular}{|c|c|c|c|c|c|c|c|}
\hline \multirow{3}{*}{$\begin{array}{l}\text { Comparison } \\
D . \text { borea }\end{array}$} & \multirow{3}{*}{$\begin{array}{c}\text { SEX } \\
\delta \\
\end{array}$} & \multicolumn{2}{|c|}{$\begin{array}{l}\text { Hindlimb L } \\
\text { vs SVL }\end{array}$} & \multicolumn{2}{|c|}{$\begin{array}{l}\text { Head L } \\
\text { vs SVL }\end{array}$} & \multirow{3}{*}{$\begin{array}{c}\begin{array}{c}\text { Head L vs } \\
\text { Head } W\end{array} \\
\mathrm{a}=0.565 \pm 0.065 \\
\mathrm{i}=0.230 \\
\mathrm{a}=0.554 \pm 0.086 \\
\mathrm{i}=0.310\end{array}$} & \multirow{3}{*}{$\begin{array}{c}\text { Loreals } \\
\begin{array}{c}F=0.01 \\
\text { d.f. }=1,94 \\
P=0.921\end{array}\end{array}$} \\
\hline & & $\begin{array}{c}a=0.052 \pm 0.007 \\
i=0.590\end{array}$ & \multirow{2}{*}{$\begin{array}{c}F=5.67 \\
\text { d.f. }=1,92 \\
P=0.019\end{array}$} & $\begin{array}{c}a=0.073 \pm 0.006 \\
i=2.99\end{array}$ & \multirow{2}{*}{$\begin{array}{c}F=2.06 \\
\text { d.f. }=1,94 \\
P=0.155\end{array}$} & & \\
\hline & & $\begin{array}{c}\mathrm{a}=0.025 \pm 0.009 \\
\mathrm{i}=0.30\end{array}$ & & $\begin{array}{c}a=0.061 \pm 0.007 \\
i=3.88\end{array}$ & & & \\
\hline \multirow[t]{2}{*}{ D. pax } & $\delta$ & $\begin{array}{c}a=0.065 \pm 0.010 \\
i=-1.15\end{array}$ & \multirow{2}{*}{$\begin{array}{l}F=35.93 \\
\text { d.f. }=1,79 \\
P<0.001\end{array}$} & $\begin{array}{c}a=0.082 \pm 0.009 \\
i=2.41\end{array}$ & \multirow{2}{*}{$\begin{array}{c}F=2.44 \\
\text { d.f. }=1,79 \\
P=0.123\end{array}$} & $\begin{array}{c}a=0.547 \pm 0.103 \\
i=0.443\end{array}$ & \multirow{2}{*}{$\begin{array}{c}F=2.54 \\
\text { d.f. }=1,80 \\
P=0.115\end{array}$} \\
\hline & $q$ & $\begin{array}{c}a=0.027 \pm 0.005 \\
i=0.27\end{array}$ & & $\begin{array}{c}a=0.066 \pm 0.005 \\
i=3.33\end{array}$ & & $\begin{array}{c}a=0.752 \pm 0.077 \\
i=-1.297\end{array}$ & \\
\hline \multirow[t]{2}{*}{ D. desmosa } & $\delta$ & $\begin{array}{c}a=0.072 \pm 0.012 \\
i=-1.83\end{array}$ & \multirow{2}{*}{$\begin{array}{c}F=0.24 \\
\text { d.f. }=1,36 \\
P=0.624\end{array}$} & $\begin{array}{c}a=0.085 \pm 0.008 \\
i=2.33\end{array}$ & \multirow{2}{*}{$\begin{array}{c}F=0.52 \\
\text { d.f. }=1,36 \\
P=0.477\end{array}$} & $\begin{array}{c}a=0.676 \pm 0.111 \\
i=-0.699\end{array}$ & \multirow{2}{*}{$\begin{array}{c}F=0.19 \\
\text { d.f. }=1,36 \\
P=0.662\end{array}$} \\
\hline & $q$ & $\begin{array}{c}a=0.059 \pm 0.023 \\
i=-2.20\end{array}$ & & $\begin{array}{c}a=0.073 \pm 0.015 \\
i=2.87\end{array}$ & & $\begin{array}{c}a=0.572 \pm 0.208 \\
i=0.450\end{array}$ & \\
\hline
\end{tabular}

Table 4 Statistical analysis of pairwise interspecific differences between each of $D$. desmosa, D. pax, and $D$. borea for selected mensural and meristic characters. The available sample of $D$. tealei is too small to yield significant results.

\begin{tabular}{|c|c|c|c|c|c|c|c|}
\hline Comparison & SEX & SVL & Ventrals & Head L & Eye $W$ & Hindlimb L & Loreals \\
\hline \multirow[t]{2}{*}{ pax vs desmosa } & $\delta$ & $\begin{array}{l}F=3.582 \\
\text { d.f. }=1,65 \\
P=0.063\end{array}$ & $\begin{array}{c}F=27.707 \\
\text { d.f. }=1,66 \\
P<0.001\end{array}$ & $\begin{array}{l}F=7.002 \\
\text { d.f. }=1,66 \\
P=0.010\end{array}$ & $\begin{array}{c}F=5.452 \\
\text { d.f. }=1,65 \\
P=0.023\end{array}$ & $\begin{array}{l}F=0.037 \\
\text { d.f. }=1,66 \\
P=0.847\end{array}$ & $\begin{array}{l}F=3.149 \\
\text { d.f. }=1,66 \\
P=0.081\end{array}$ \\
\hline & $q$ & $\begin{array}{c}F=0.817 \\
\text { d.f. }=1,53 \\
P=0.370\end{array}$ & $\begin{array}{l}F=27.178 \\
\text { d.f. }=1,53 \\
P<0.001\end{array}$ & $\begin{array}{c}F=1.113 \\
\text { d.f. }=1,53 \\
P=0.296\end{array}$ & $\begin{array}{l}F=0.318 \\
\text { d.f. }=1,53 \\
P=0.575\end{array}$ & $\begin{array}{c}F=3.936 \\
\text { d.f. }=1,53 \\
P=0.053\end{array}$ & $\begin{array}{l}F=3.560 \\
\text { d.f. }=1,53 \\
P=0.065\end{array}$ \\
\hline \multirow[t]{2}{*}{ pax vs borea } & $\delta$ & $\begin{array}{l}F=5.118 \\
\text { d.f. }=1,83 \\
P=0.026\end{array}$ & $\begin{array}{l}F=0.612 \\
\text { d.f. }=1.84 \\
P=0.436\end{array}$ & $\begin{array}{c}F=7.084 \\
\text { d.f. }=1,84 \\
P=0.009\end{array}$ & $\begin{array}{l}F=4.618 \\
\text { d.f. }=1,83 \\
P=0.035\end{array}$ & $\begin{array}{c}F=73.475 \\
\text { d.f. }=1,83 \\
P<0.001\end{array}$ & $\begin{array}{c}F=0.237 \\
\text { d.f. }=1,82 \\
P=0.628\end{array}$ \\
\hline & $q$ & $\begin{array}{l}F=11.196 \\
\text { d.f. }=1,88 \\
P=0.001\end{array}$ & $\begin{array}{l}F=12.295 \\
\text { d.f. }=1,88 \\
P=0.001\end{array}$ & $\begin{array}{c}F=6.860 \\
\text { d.f. }=1,88 \\
P=0.010\end{array}$ & $\begin{array}{l}F=6.391 \\
\text { d.f. }=1,88 \\
P=0.013\end{array}$ & $\begin{array}{c}F=45.916 \\
\text { d.f. }=1,87 \\
P<0.001\end{array}$ & $\begin{array}{c}F=1.173 \\
\text { d.f. }=1,88 \\
P=0.282\end{array}$ \\
\hline \multirow[t]{2}{*}{ desmosa vs borea } & $\delta$ & $\begin{array}{c}F=1.232 \\
\text { d.f. }=1,107 \\
P=0.270\end{array}$ & $\begin{array}{c}F=16.981 \\
\text { d.f. }=1,108 \\
P<0.001\end{array}$ & $\begin{array}{c}F=3.264 \\
\text { d.f. }=1,108 \\
P=0.074\end{array}$ & $\begin{array}{c}F=1.015 \\
\text { d.f. }=1,65 \\
P=0.318\end{array}$ & $\begin{array}{c}F=10.466 \\
\text { d.f. }=1,107 \\
P=0.002\end{array}$ & $\begin{array}{c}F=4.551 \\
\text { d.f. }=1,63 \\
P=0.037\end{array}$ \\
\hline & $q$ & $\begin{array}{c}F=0.131 \\
\text { d.f. }=1,103 \\
P=0.718\end{array}$ & $\begin{array}{c}F=11.240 \\
\text { d.f. }=1,103 \\
P=0.001\end{array}$ & $\begin{array}{c}F=0.004 \\
\text { d.f. }=1,103 \\
P=0.952\end{array}$ & $\begin{array}{l}F=1.385 \\
\text { d.f. }=1,64 \\
P=0.244\end{array}$ & $\begin{array}{c}F=19.146 \\
\text { d.f. }=1,102 \\
P<0.001\end{array}$ & $\begin{array}{l}F=0.931 \\
\text { d.f. }=1,64 \\
P=0.338\end{array}$ \\
\hline
\end{tabular}

butleri, the latter also displayed considerable heterogeneity which broadly manifested itself as three geographically-based clusters herein referred to as 'western', 'central', and 'eastern' (Figure $4 \mathrm{C}$, Appendix 1). Thus the final outcome of the four PCOAs was the recognition of nine Operational Taxonomic Units (OTUs) among the 41 specimens examined, each diagnosable from all others using stepwise PCoA of the allozyme data. Table 5 compares allele frequencies for each OTU at the 34 informative loci, while Table 6 presents pairwise genetic distance (Nei D and \% fixed difference) values.

In general, each of the OTUs is well-differentiated genetically from all others, with only five of the 36 pairwise comparisons involving fewer than six fixed differences (equivalent to $12 \%$ FD). Regarding the five exceptions, all but one occurred among the four OTUs identified within group C (butleri) haroldi); indeed, in the case of $D$. haroldi versus 'central' $D$. butleri the two OTUs shared alleles at all loci $(0 \%$ FD, Table 6$)$. 
Figure 3 Principal Co-ordinates Analysis of the 41 specimens included in the allozyme study. The 'desert' and 'Cape Range' morphotypes are listed in this and all subsequent figures as $D$. desmosa and $D$. tealei, respectively, reflecting the ultimate taxonomic arrangement. The relative $\mathrm{PCOA}$ scores have been plotted for the first ( $X$-axis) and second ( $Y$-axis) dimensions, which individually explained $43 \%$ and $14 \%$ respectively of the total multivariate variation.

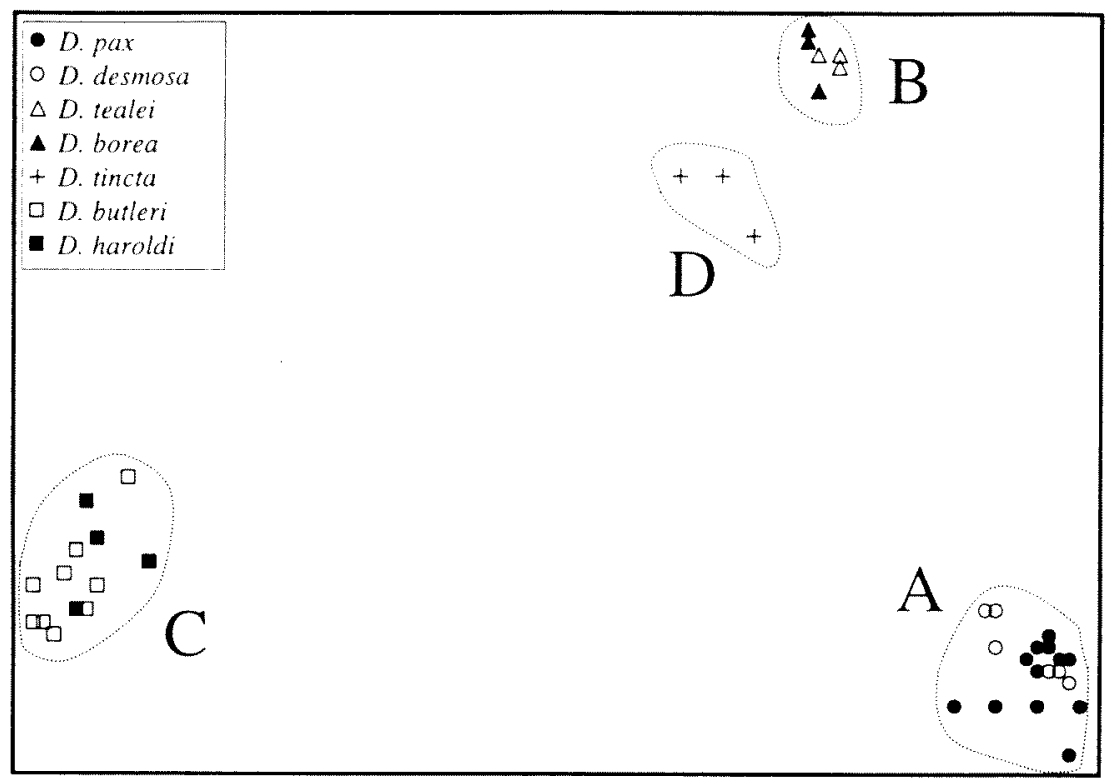

The only other pairwise comparison not characterized by multiple fixed differences is that between typical pax and the 'desert' morphotype. These OTUs displayed a single fixed difference (= $2 \%$ FD) and a modest Nei D of 0.08 (Table 6). In contrast, the 'Cape Range' morphotype shows fixed differences at $21 \%$ of loci to each of D. pax and the 'desert' morphotype (Nei D $=0.25-0.27$ ) and a closer association with $D$. borea $(12 \% \mathrm{FD}$ and Nei D $=0.16$ ). Pairwise contrasts within the $D$. butleri/ haroldi group range from $0-14 \%$ for fixed differences and 0.04 to 0.21 for Nei D, with a closer affinity between $D$. haroldi and eastern $D$. butleri on the one hand, and between 'western' and 'central' populations of $D$. butleri on the other.

The Neighbour-Joining tree constructed from pairwise Nei D values (Figure 5) shows a deep division of the OTUs into two groups, one containing $D$. butleri and $D$. haroldi, and the other containing $D$. tincta, $D$. pax and $D$. borea and both the 'desert' and 'Cape Range' morphotypes. Within this latter group, $D$. tincta appears to be the most divergent, with the remaining four OTUs forming a common group made up of two pairs of OTUs: pax + 'desert' and borea + 'Cape Range'.

Figure 4 Principal Co-ordinates Analyses for each of the three groups identified in the initial PCoA (Figure 3). A) PCoA of group A specimens; the first and second dimensions individually explained $34 \%$ and $13 \%$ respectively of the total variance. B) $\mathrm{PCoA}$ of group B specimens; the first and second dimensions individually explained $75 \%$ and $16 \%$ respectively of the total variance. C) $\mathrm{PCOA}$ of group C specimens; the first and second dimensions individually explained $26 \%$ and $15 \%$ respectively of the total variance. Codes, legends, and general layout as per Figure 3 .

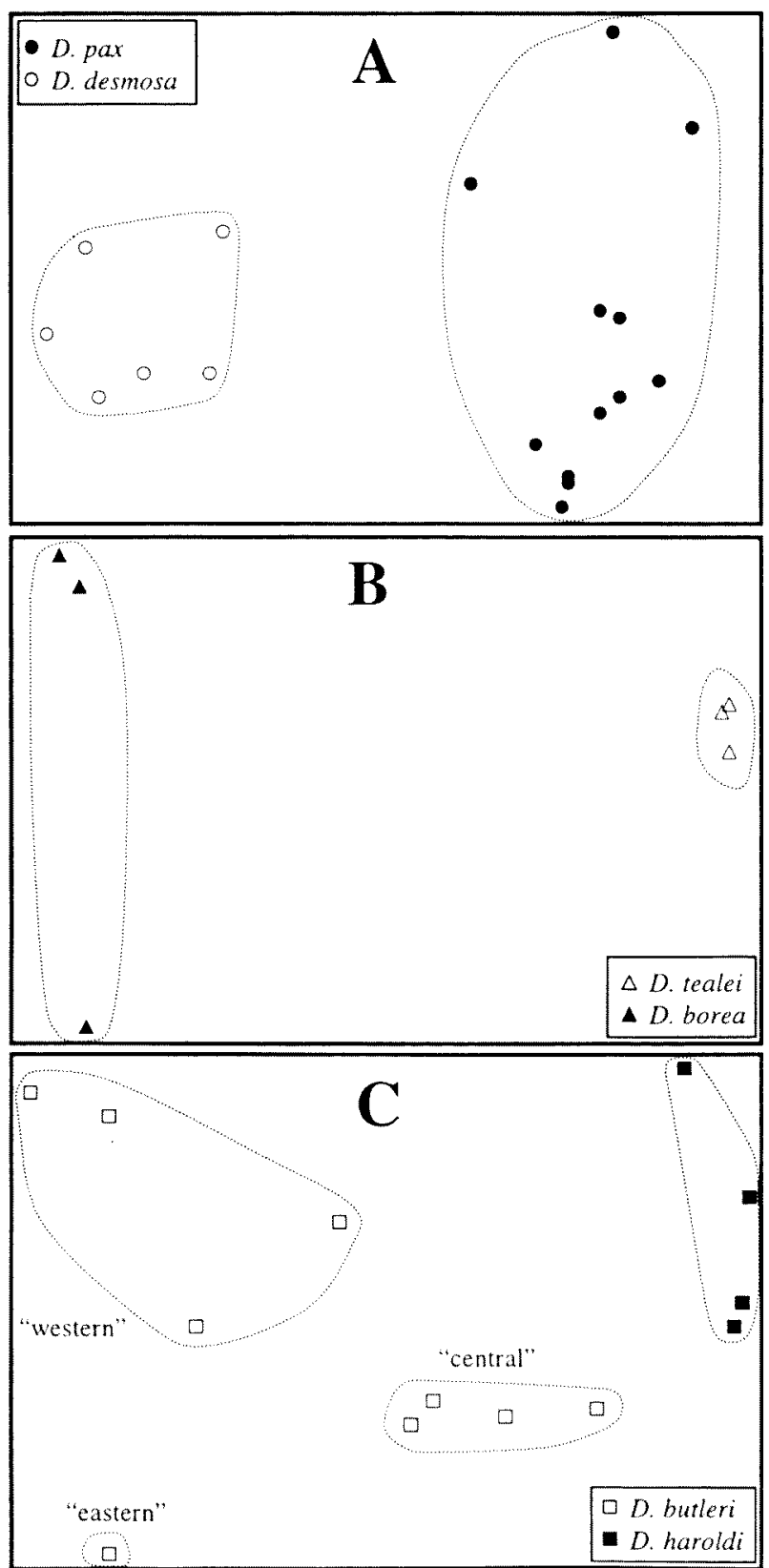


Table 5 Allele frequencies at 34 variable loci for the nine OTUs identified in the allozyme study. For polymorphic loci, the frequencies of all but the rarer/rarest alleles are expressed as percentages and shown as superscripts (allowing the frequency of each rare allele to be calculated by subtraction from $100 \%$ ). A dash indicates no genotypes assignable at this locus.

\begin{tabular}{|c|c|c|c|c|c|c|c|c|c|}
\hline Locus & pax & desmosa & tealei & borea & tincta & $\begin{array}{c}\text { butleri } \\
\text { "western" }\end{array}$ & $\begin{array}{l}\text { butleri } \\
\text { "central" }\end{array}$ & $\begin{array}{c}\text { butleri } \\
\text { "eastern" }\end{array}$ & haroldi \\
\hline Aconl & $a$ & $\mathrm{a}$ & $\mathrm{a}$ & $\mathrm{a}$ & $\mathrm{a}$ & $b^{\text {int }}, c$ & $a^{511}, b$ & $\mathrm{~b}$ & $a^{75}, b$ \\
\hline $\operatorname{Acon} 2$ & $d^{*}, b$ & $c^{5 \%}, d$ & c & $c^{* 3}, \mathrm{~d}$ & $b^{5 x}, c^{33}, a$ & $a^{k x}, b$ & $\mathrm{~d}$ & $d^{(4)}, e$ & $a^{3+4}, d^{37}, c$ \\
\hline Acpl & a & $\mathrm{a}$ & $\mathrm{a}$ & $b$ & $\mathrm{a}$ & $\mathrm{a}$ & a & $\mathrm{a}$ & a \\
\hline Acp2 2 & $\mathrm{~b}$ & $\mathrm{~b}$ & $\mathrm{~b}$ & $b$ & $\mathrm{a}$ & $\mathrm{a}$ & $\mathrm{a}$ & a & $\mathrm{a}$ \\
\hline$A C y C$ & $\mathrm{~b}^{6,2}, \mathrm{a}$ & $b$ & $\mathrm{a}$ & a & $a^{6 \%}, b$ & a & a & $\mathrm{a}$ & $a^{75}, c$ \\
\hline Ada & $\mathrm{b}$ & $b^{42}, c$ & $\mathrm{~b}$ & $b$ & $b^{6 \%}, d$ & $b$ & $b$ & $b$ & $b^{\alpha \gamma}, a$ \\
\hline Adhl & b & $c^{5}, b$ & $b$ & $b$ & $b$ & $b$ & $b^{*}, a$ & $\mathrm{~b}$ & $\mathrm{~b}$ \\
\hline Adh2 & $\mathrm{d}$ & $a^{511}, c$ & c & c & $\mathrm{a}$ & c & $b^{6,3}, c$ & c & $\mathrm{b}$ \\
\hline $\mathrm{Ca}$ & $\mathrm{a}$ & $\mathrm{a}$ & a & $a$ & a & $b$ & $\mathrm{~b}$ & $b$ & $b$ \\
\hline Dia & $b, e$ & $b^{\prime \prime}, a$ & $h^{x+k}, j$ & $h^{66}, g^{17}, d$ & $g^{k 3}, h$ & $\mathrm{~g}^{35}, \mathrm{i}$ & $c^{25}, f^{25}, g^{13}, i^{13}, h^{12}, j$ & $g$ & - \\
\hline Enol & $c$ & c & $\mathrm{b}$ & c & $c$ & $c^{62}, b^{25}, a$ & c & c & $c^{75}, b$ \\
\hline Est2 & $d^{6,3}, e$ & $\mathrm{~d}$ & $\mathrm{~b}$ & $b^{6,}, c$ & $b^{75}, a$ & $\mathrm{~b}$ & $b$ & $b$ & $b^{8 k}, c$ \\
\hline$F d p$ & c & $c^{42}, b$ & a & $\mathrm{a}$ & a & a & $\mathrm{a}$ & a & $\mathrm{a}$ \\
\hline Fum & b & $b$ & $b$ & $b$ & $\mathrm{~b}$ & $b^{k *}, d$ & $b^{* * *}, d$ & $b^{5 x}, c$ & $\mathrm{~b}^{7,}, \mathrm{a}^{13}, \mathrm{~d}$ \\
\hline Gda & $c$ & $c$ & e & $d$ & $\mathrm{~d}$ & $c^{*}, a$ & c & c & $c^{k 7}, b$ \\
\hline Glo & $c^{4 / 4}, b$ & $c^{4,3}, a$ & c & $c$ & c & $\mathrm{d}$ & $\mathrm{d}$ & d & $\mathrm{d}$ \\
\hline Got 1 & $b^{+/ a}, a$ & $b$ & $b$ & $b$ & b & $b$ & b & c & $b$ \\
\hline Got2 & $b^{4,3}, a$ & a & $b$ & $\mathrm{~b}$ & $\mathrm{~b}$ & $c$ & c & c & $\mathrm{C}^{75}, \mathrm{~d}$ \\
\hline Gpd & $b$ & $\mathrm{~b}$ & $b$ & b & $b^{6,}, a$ & $b$ & $b$ & $b$ & $b$ \\
\hline$G p^{i}$ & $b$ & $b^{42}, a$ & $b$ & $b$ & $\mathrm{~b}$ & c & c & c & c \\
\hline Guk & $b^{n}, a$ & $\mathrm{~b}$ & $b$ & $a^{k 3}, b$ & a & $a$ & a & a & a \\
\hline$I d h 2$ & c & c & c & $c$ & c & $b^{x y}, a$ & b & $b$ & $b^{75}, a^{13}, d$ \\
\hline Mel & C & $c^{b i}, a$ & c & $\mathrm{c}$ & c & $b^{5,}, c$ & $\mathrm{~b}$ & $b$ & $c^{k z}, b$ \\
\hline Mpi & b & $b$ & $\mathrm{~b}$ & $b$ & $b$ & $a$ & a & $\mathrm{a}$ & $\mathrm{a}$ \\
\hline Ndpk1 & $a$ & a & $a$ & $a$ & a & $b$ & $\mathrm{~b}$ & $b$ & $b$ \\
\hline Ndpk2 & $\mathrm{b}$ & $b^{k, 3}, c$ & $\mathrm{~b}$ & $b^{\alpha_{3}, a}$ & $b$ & $b$ & $b^{k x}, \mathrm{~d}$ & $b$ & b \\
\hline PepA & $c^{62}, b$ & c & c & c & c & $\mathrm{C}^{4 \gamma}, \mathrm{a}$ & c & $\mathrm{d}$ & c \\
\hline$P$ epB & $f^{46}, e$ & $\mathrm{f}^{42}, \mathrm{~d}$ & $\mathrm{e}$ & e & e & $e^{-5, b}$ & $e^{62}, b$ & $\mathrm{a}$ & $b^{50}, e^{25}, a^{13}, c$ \\
\hline PepD & $c^{54}, d$ & $\mathrm{~d}^{5,}, \mathrm{c}$ & $\mathrm{c}^{\infty}, \mathrm{a}$ & $d^{5 x}, c^{3}, f$ & $d^{5,3}, b$ & $\mathrm{~d}^{63,}, \mathrm{c}^{25}, \mathrm{f}$ & $\mathrm{d}$ & $c^{51}, d$ & $\mathrm{~d}^{63}, \mathrm{f}^{13}, \mathrm{e}^{12}, \mathrm{~g}$ \\
\hline $6 P g d$ & $b^{n+w}, c$ & $\mathrm{~b}$ & $b^{* \gamma}, a$ & $b$ & $b^{6 \%, c}$ & $\mathrm{~d}$ & $\mathrm{~d}$ & e & $\mathrm{d}$ \\
\hline Pgm1 & c & $c " b$ & $e$ & $g$ & d & $c^{6}, a$ & $e^{x x}, f$ & $\mathrm{f}$ & $e^{x /}, f$ \\
\hline Pgm2 & $a$ & $a$ & $\mathrm{a}$ & $a^{* 3}, b$ & a & $a$ & $\mathrm{a}$ & $\mathrm{a}$ & $\mathrm{a}$ \\
\hline Sod & $d^{+\infty}, g$ & $\mathrm{~d}$ & $\mathrm{~d}$ & c & $\mathrm{d}$ & $d$ & $d^{75}, a$ & $\mathrm{~d}$ & $a^{51}, b^{25}, e^{13}, f$ \\
\hline Srdh & $b^{42}, a$ & b & $b$ & $b$ & $d^{6,}, b$ & $b^{5 x}, c$ & c & c & c \\
\hline
\end{tabular}

Table 6 Genetic distance matrices for the nine OTUs of Delma identified by the Principal Co-ordinates Analyses. Lower triangle $=\% \mathrm{FD}$; upper triangle $=\mathrm{Nei}$ Ds

\begin{tabular}{|c|c|c|c|c|c|c|c|c|c|}
\hline OTU & pax & desmosa & tealei & borea & tincta & $\begin{array}{c}\text { butleri } \\
\text { "western" }\end{array}$ & $\begin{array}{c}\text { butleri } \\
\text { "central" }\end{array}$ & $\begin{array}{c}\text { butleri } \\
\text { "eastern" }\end{array}$ & haroldi \\
\hline pax & - & 0.08 & 0.25 & 0.27 & 0.27 & 0.55 & 0.55 & 0.68 & 0.53 \\
\hline desmosa & 2 & - & 0.27 & 0.30 & 0.31 & 0.58 & 0.61 & 0.74 & 0.59 \\
\hline tealei & 21 & 21 & - & 0.16 & 0.27 & 0.48 & 0.53 & 0.68 & 0.49 \\
\hline borea & 21 & 23 & 12 & - & 0.17 & 0.50 & 0.54 & 0.67 & 0.49 \\
\hline tincta & 21 & 21 & 16 & 12 & - & 0.40 & 0.43 & 0.56 & 0.40 \\
\hline butleri 'western' & 37 & 40 & 35 & 35 & 28 & - & 0.07 & 0.13 & 0.10 \\
\hline butleri central' & 40 & 42 & 37 & 35 & 33 & 5 & - & 0.15 & 0.04 \\
\hline butleri eastern' & 47 & 49 & 49 & 44 & 42 & 14 & 9 & - & 0.21 \\
\hline haroldi & 38 & 43 & 36 & 36 & 31 & 7 & 0 & 12 & - \\
\hline
\end{tabular}




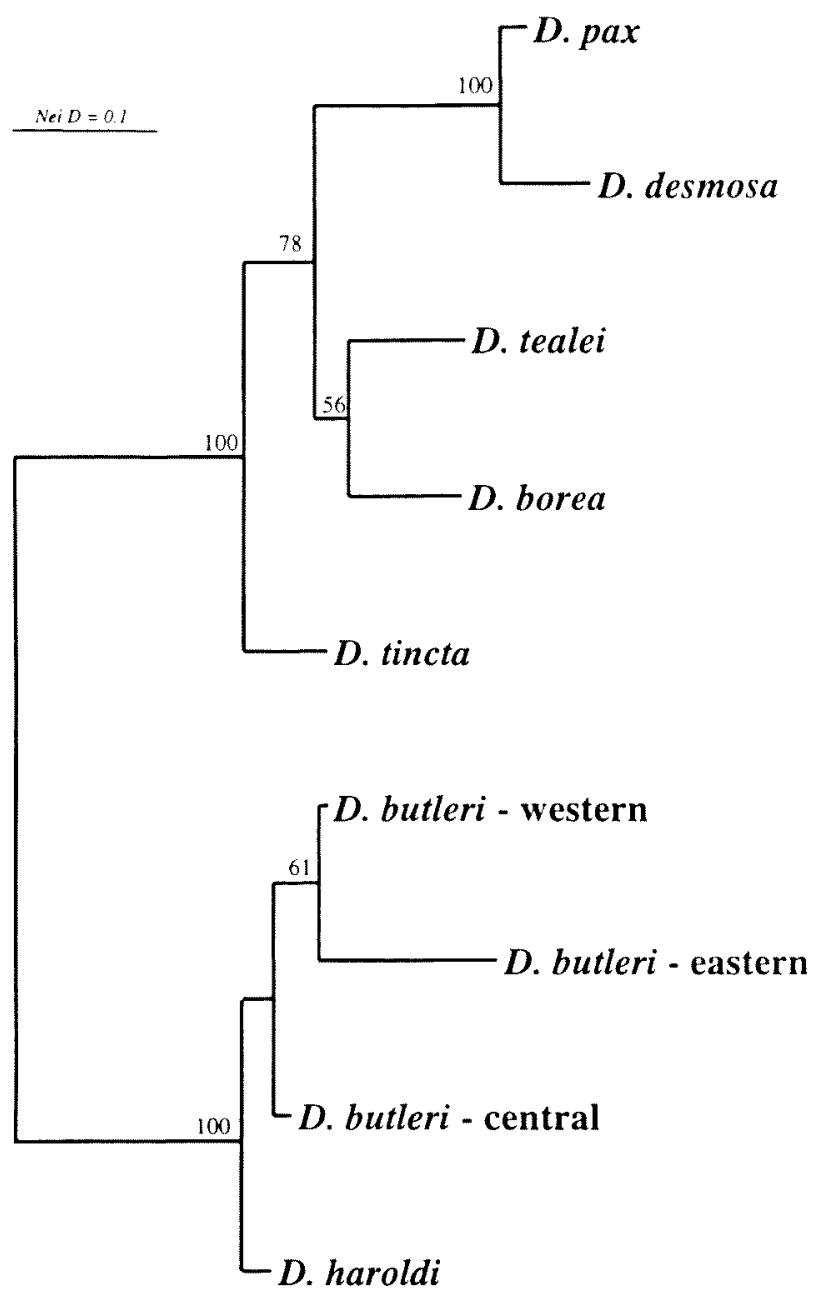

Figure 5 Neighbor-joining tree depicting the phylogenetic affinities of nine OTUs of Delma, based on Nei distances and rooted at the midpoint of the longest branch. Bootstrap proportions of $50 \%$ or greater from 100 pseudo-replications are indicated for all nodes. Scale represents a Nei D of 0.1 .

The case for recognition of the 'Cape Range' morphotype as a distinct species is strongly supported by the genetic evidence. Although this population was historically associated first with $D$. pax and then with $D$. tincta, its genetic affinities clearly lie with $D$. borea. Nevertheless, the 'Cape Range' morphotype and $D$. borea are welldifferentiated genetically, with a total of six fixed differences and a Nei D of 0.16 between them. This is equivalent to the observed genetic differentiation between $D$. borea and $D$. tincta (12\%FD and Nei D of 0.17 ), two species that are broadly sympatric (but rarely syntopic; Shea 1991) across northern Australia. Furthermore, the 'Cape Range' morphotype is readily distinguished on several morphological criteria from $D$. borea (see below).

In contrast, the 'desert' morphotype is weakly differentiated from typical $D$. pax, with only a single observed fixed difference in their allozyme profiles. Despite this, there remains a strong case for treating these morphologically distinct populations as discrete evolutionary lineages. First, in addition to their single fixed difference at the Adh2 locus, they also displayed major differences in allele frequency at a further three loci $\left(A \operatorname{con} 2^{\mathrm{d}}\right.$ $\mathrm{DP}=63 \%$, Adh $1^{\mathrm{b}} \mathrm{DP}=75 \%$, Got $2^{\mathrm{b}} \mathrm{DP}=83 \%$; Table 5). Second, the spatial distribution of variation in each of the 'near fixed' loci within each taxon is not clustered in specific localities around the periphery of the Pilbara, as might be expected if regular gene flow was occurring between the two morphotypes, nor is it arranged in any geographic pattern that might be identified as a genetic cline. Last, each of the $D$. pax and the 'desert' morphotypes have quite large geographic distributions (see below), which nevertheless appear to abut around the perimeter of the Pilbara uplands, involving a total distance of many hundreds of kilometres. Such a geographic arrangement ought to facilitate gene flow between the two forms, yet they appear to maintain their morphological distinctiveness across their ranges.

In the following section we diagnose two new species of Delma, redefine $D$. pax as a taxon restricted to the Pilbara uplands, and comment on the distribution and morphology of $D$. borea populations in Western Australia.

\section{SYSTEMATICS}

Delma tealei sp. nov.

Figures 6-7

\section{Material examined}

\section{Holotype}

153811 in the Western Australian Museum, an adult female collected on 12 September 2003 by B. Maryan and D. Algaba on Charles Knife Road, Cape Range, Western Australia $\left(22^{\circ} 07^{\prime} 08^{\prime \prime} \mathrm{S} 114^{\circ} 03^{\prime} 44^{\prime \prime} \mathrm{E}\right)$. Liver sample preserved in $-75^{\circ} \mathrm{C}$ ultrafreeze at W.A. Museum.

\section{Paratypes}

Sex indicated in brackets.

Western Australia: 52934-35 (both F) Shothole Canyon (22. $\left.03^{\prime} \mathrm{S} 114^{\circ} 02^{\prime} \mathrm{E}\right) ; 82532$ (M) $6 \mathrm{~km} \mathrm{~W}$ Exmouth (21 $\left.{ }^{\circ} 56^{\prime} \mathrm{S} 114^{\circ} 04^{\prime} \mathrm{E}\right) ; 88548$ (F) $2 \mathrm{~km}$ E Yardie

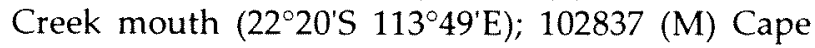
Range National Park $\left(22^{\circ} 09^{\prime} 01^{\prime \prime S} 113^{\circ} 59^{\prime} 52^{\prime \prime} \mathrm{E}\right)$; 153813 (M) 2 km S Yardie Homestead Caravan Park (21 $\left.{ }^{\circ} 53^{\prime} 37^{\prime \prime S} 114^{\circ} 00^{\prime} 34^{\prime \prime E}\right) ; 153819$ (M) Shothole

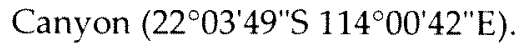

\section{Diagnosis}

A moderately small species of Delma (SVL up to $88 \mathrm{~mm}$ ) with modally 14 midbody scales, two pairs of supranasals and relatively plain colouration apart from variegated ventrolateral scales on forebody. 


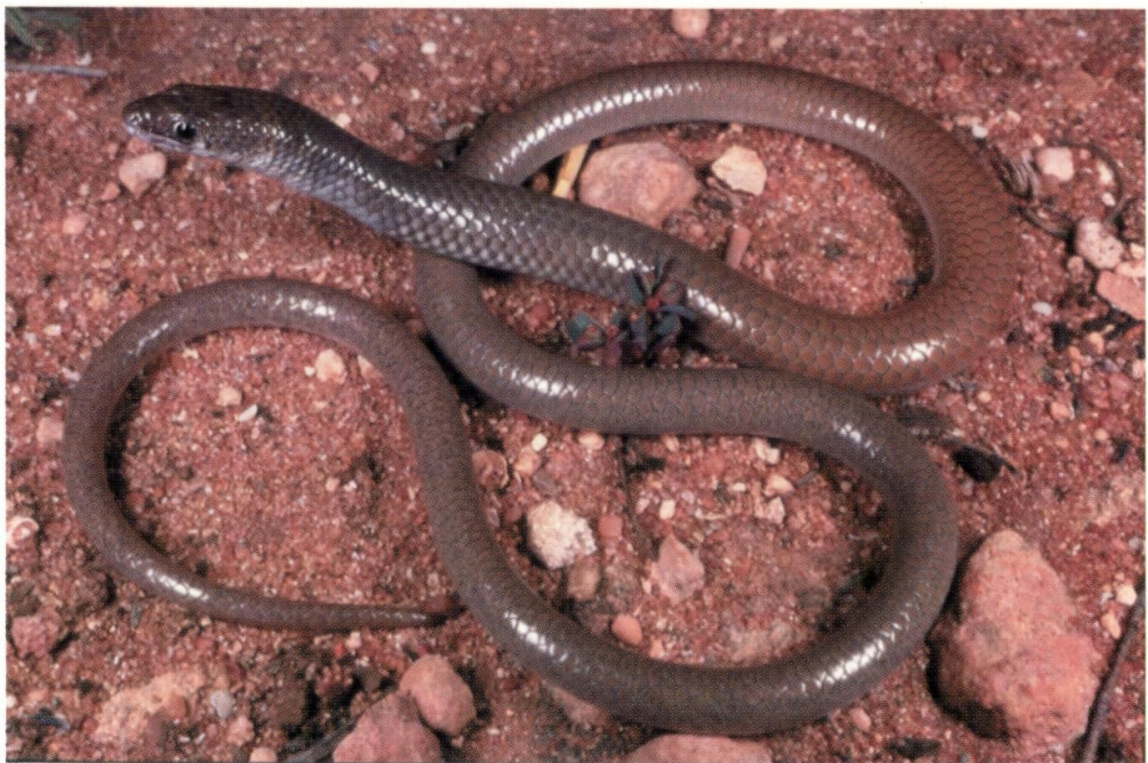

Figure 6 Holotype (153811) of Delma tealei, photographed in life (B. Maryan).

Adults lack any trace of dark markings on head or neck. Differs from the otherwise similar $D$. borea in lower modal midbody scale count, typically the third supralabial positioned below the eye, absence of pattern on head and neck in adults and longer hindlimb flaps in both sexes.

\section{Description}

Rostral with obtuse apex, penetrating between rostral supranasals; two pairs of supranasals, caudal pair much larger; rostral supranasals in moderate contact with first supralabial; caudal supranasals in point to moderate contact with nostril; postnasal single; loreals 5-9, subequal; suboculars 3-4; supraciliaries 5, fifth much larger; supraoculars 2, second wider than first; supralabials 5, third elongate and positioned below eye, fifth much smaller; infralabials 4, third elongate; occipital scale present; upper temporals 2. General form of head and details of scalation illustrated in Figure 7. Midbody scale rows 14; transversely enlarged ventral scales 50-52; hindlimb scales 8 .

Morphological Variation: 82532 has a small scale partly wedged between second and third supralabial on left side; 52934 has upper temporals divided on both sides.

\section{Colouration and patterning}

In preservative, upper and lateral surfaces light grey or light to dark brown, head slightly darker. Supralabials pale to dark brown and infralabials pale with brownish vertical streaks or blotches mostly centered on first and third sutures along series. Lateral scales on forebody typically variegated, bases greyish white to white, centres blackish (mostly a dark smudge) and apices greyish
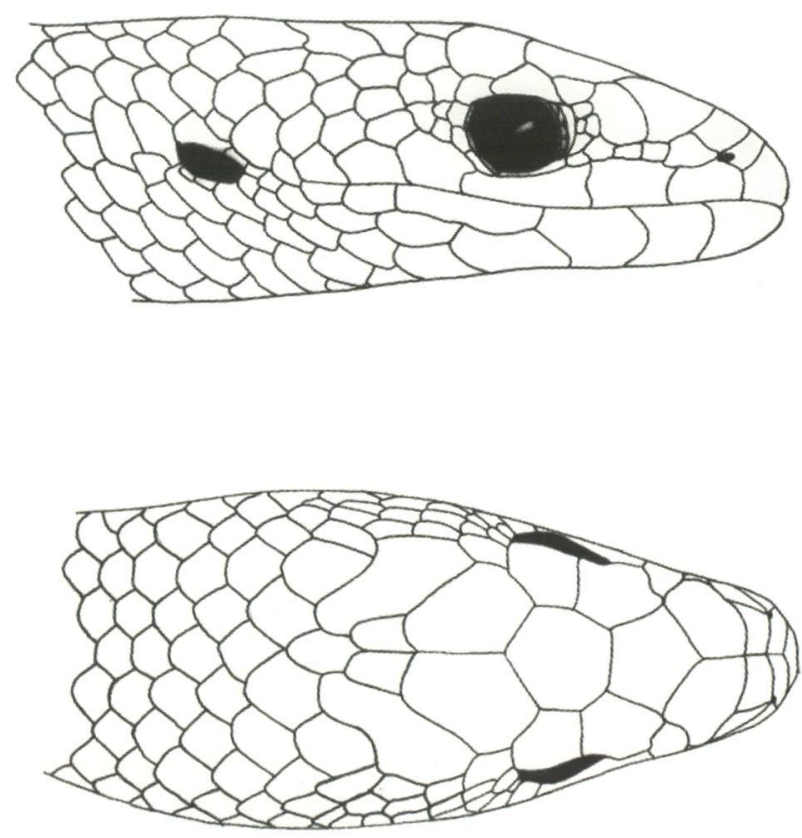

Figure 7 Head scalation of Delma tealei holotype (153811) in lateral (top) and dorsal (bottom) views.

to brownish grey. Variation includes individuals (e.g., 102837) with barely discernible variegation; and others (e.g., 52934) with distinct white-centred scales bordered by black smudging and with light brown apices. Lower surface greyish white or white with diffuse dark smudging on posterior edges of some scales.

In life, a subtle pinkish flush is noticeable on the dorsal and lateral scales immediately forward of and behind vent (e.g., 153811, 153813, 153819); this colour is lost in preservative.

No immature specimens are available for this 
species. Accordingly, it is not known whether or not it displays the ontogenetic fading of head and neck patterning displayed by $D$. pax and some $D$. borea (see below for details).

\section{Details of Holotype}

Snout-vent length $(\mathrm{mm}) 79$; tail 210 ; loreals 8 ; midbody scale rows 14 ; ventrals 52 ; hindlimb scales 8. Light grey upper and lateral surface, supralabials smudged grey aligned with dark vertical streaks on infralabial sutures 1-3, variegated lateral scales on forebody bases greyish white, apices greyish and some scales with blackish centres. Lower surface white and unpatterned.

\section{Etymology}

Named for zoologist Mr Roy Teale, in recognition of his contribution to Western Australian natural history and the collections of the Western Australian Museum, and his active support of numerous taxonomic research projects.

\section{Distribution and sympatry}

Apparently restricted to the Cape Range Peninsula of North West Cape in Western Australia
(Figure 8), a heavily dissected limestone plateau, sparsely vegetated with Triodia, shrubs and low eucalypts; gorges within the range are more heavily vegetated (Storr and Hanlon 1980).

Three other species of Delma are recorded on the Cape Range Peninsula. Delma nasuta Kluge, 1974 and $D$. tincta De Vis, 1888 are known from multiple localities and the regional sample is consistent with other populations of these widespread taxon. A third taxon, currently associated with $D$. australis Kluge, 1974 of southern Australia, is known from a single specimen (132470) collected at Shothole Canyon. Specimens of $D$. tincta were collected on the same occasion as $D$. tealei at four localities (Shothole Canyon, 52933; Cape Range National Park, 102838; 2 km S Yardie Homestead Caravan Park, 153814; Charles Knife Road, 153820).

\section{Comparison with other species}

Delma tealei will be compared first with $D$. borea and $D$. tincta, the two species with which it is most similar to, then with each of the regionally sympatric $D$. nasuta and $D$. australis, and finally with geographically distant congeners with which it shares important characters.

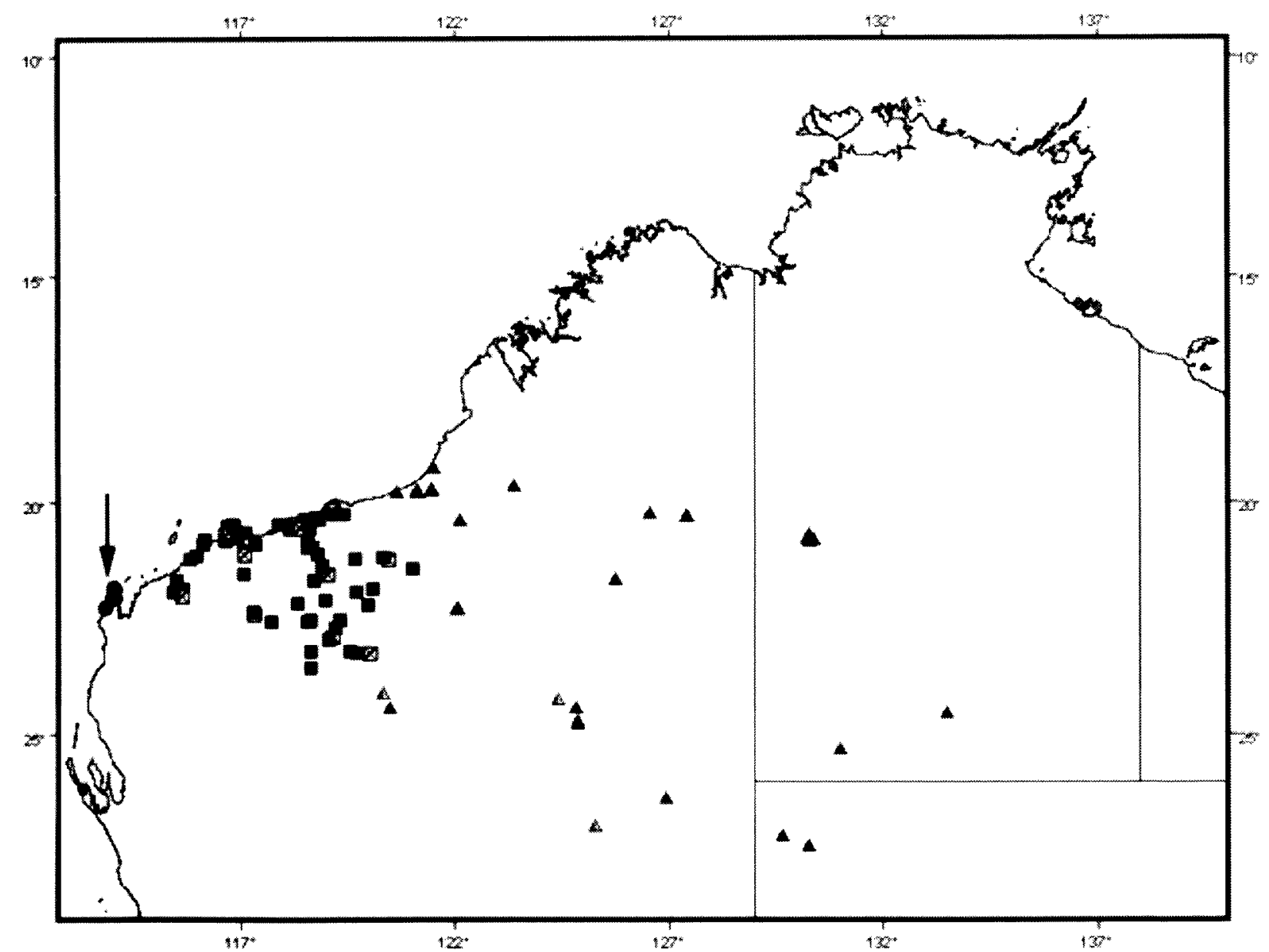

Figure 8 Map of northwestern Australia showing location of specimens examined in this study of Delma tealei (circles with arrow), Delma desmosa (triangles) and Delma pax (squares). Open symbols with cross indicate specimens examined in allozyme analysis. 
Delma tealei is morphologically most similar to populations of $D$. borea on the western Pilbara islands (e.g., 28656, 37371, 37406, 48559). These taxa are similar in body size and share two pairs of supranasals and some indication of variegated ventrolateral scales on the forebody. However, all populations of $D$. borea have higher midbody scale row counts (modally 16 versus 14), some indication in adults of pale brown bands on the head and neck, and typically the fourth supralabial positioned below the eye (typically the third in $D$. tealei).

Delma tealei and D. tincta share modally 14 midbody scales and indication of variegated ventrolateral scales on the forebody. Delma tincta has one pair of supranasals (two pairs in D. tealei) and dark dorsal head markings that are especially distinctive on immature specimens but remain visible on most adult specimens (Storr et al. 1990) including individuals (e.g., 52933, 102838, 153814) from some of the same localities as the new species. Delma tincta also has smaller hindlimb flaps than $D$. tealei (Table 1). The hindlimb scale counts are correspondingly lower in $D$. tincta (5 versus 8 ).

Delma nasuta from Cape Range Peninsula and elsewhere grows to larger size (SVL up to $112 \mathrm{~mm}$ versus $88 \mathrm{~mm}$ ) and has a more elongate snout, higher midbody scale row counts (modally 16 or 18 versus 14), more loreals (6-23 versus 5-9) and a reticulated or spotted body pattern formed by a dark spot or emargination on numerous body scales.

The Cape Range Peninsula specimen of $D$. 'australis' is smaller than D. tealei (SVL $57 \mathrm{~mm}$ versus up to $88 \mathrm{~mm}$ ) and further differs in having one pair of supranasals (versus two), more midbody scale rows (modally 18 versus 14), and very different patterning that includes fine black lateral bars on the neck and throat. It also shares an unusual arrangement of the loreal scales with typical D. australis (loreal row is broken by prefrontal-supralabial contact versus continuous in D. tealei).

Delma pax and $D$. desmosa are both allopatric to $D$. tealei (Figure 8). They are distinguished by higher midbody scale row counts (modally 16 versus 14) and uniformly coloured ventrolateral scales on the forebody. Adult $D$. desmosa differ further by the ontogenetic retention of dark dorsal head markings.

\section{Habitat}

The holotype was raked (using a 3-prong cultivator) from dead Triodia clumps on a low hill vegetated with Triodia and sparse shrubs on brown stony loam (Figure 9). The paratypes were collected in the same manner except for 88548 that was found beneath an exfoliated limestone slab on heavy Eucalyptus leaf litter, and 102837 that was pittrapped in a valley floor surrounded by low limestone breakaways (P. Kendrick, pers. comm.). All collection sites for this species combine hummock grass and limestone, an association that is overwhelmingly dominant on the Cape Range Peninsula.

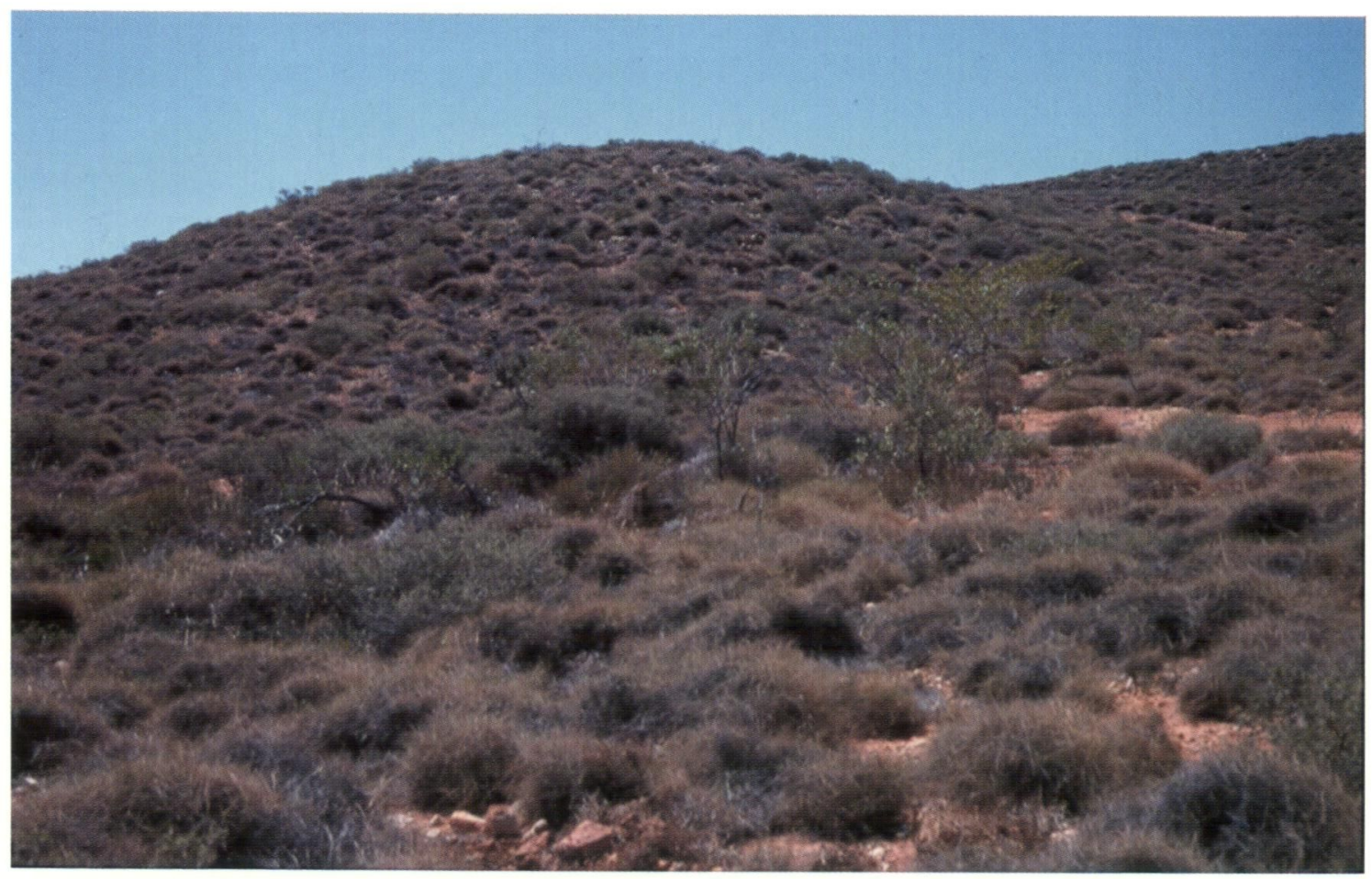

Figure 9 Low stony hills covered with dense Triodia at the Charles Knife Road, Cape Range WA, the type locality for Delma tealei (B. Maryan). 
Remarks

Delma tealei was originally thought to represent a southern outlier population of D. pax when first collected during herpetofaunal surveys (Storr and Hanlon 1980). The combination of two pairs of supranasals and third upper labial in subocular position probably influenced this decision. However, in preparation for publication of a handbook to the gekkonoid lizards of Western Australia (Storr et al. 1990), fresh examination resulted in the transfer of this population to $D$. tincta. This action probably reflected the shared condition of 14 midbody scale rows in each of $D$. tealei and $D$. tincta.

In Storr et al. (1990) the species account for $D$. tincta (incorporating $D$. tealei) included the statement 'usually one (occasionally two) pairs of supranasals' but without reference to a specific population. We consulted Kluge (1974) and also examined all Western Australian Museum holdings of $D$. tincta (see Appendix 1) to ascertain whether this statement holds true following exclusion of $D$. tealei. Kluge (1974) examined 168 specimens and encountered a single individual (22323) with unilateral division (left side) of the supranasals. Similarly, in a total of 163 specimens examined by us, we found only one example (104426) with bilateral division into two pairs of asymmetrically shaped supranasals, and another (85190) with unilateral division (right side). Both of these examinations suggest that any individual variation away from the conditional state of undivided supranasals in $D$. tincta is extremely rare. Accordingly, we believe that the reference by Storr et al. (1990) to supranasal multiplication in $D$. tincta was in specific reference to specimens from the Cape Range Peninsula referred herein to $D$. tealei. Delma inornata from eastern Australia appears to be the only species of Delma that exhibits regular intraspecific variation (around 10\%) in having either 1 or 2 pairs of supranasals (Kluge 1974: 103). Among Western Australian Delma the combination of 14 midbody scale rows and 2 pairs of supranasals is unique to $D$. tealei.

Delma tealei would probably receive an IUCN conservation rating of 'Least Concern' on account of the lack of evidence for any population decline and most of its geographic range being protected within the Cape Range National Park. However, in many areas on the Cape Range Peninsula, introduced Buffel Grass (Cenchrus ciliaris), has virtually replaced the original ground cover (Aplin 1998) and there is an identified priority to monitor and manage its spread (Keighery and Gibson 1993). Particular attention should be given to the impact on species such as Delma tealei that are probably dependent on Triodia and other hummock grasses for their survival.

\section{Delma desmosa sp. nov.}

Figures 10-12

\section{Material examined}

\section{Holotype}

102657 in the Western Australian Museum, an adult female collected on 10 October 1996 by S. van Leeuwen at Site Cooma 4, Little Sandy Desert, Western Australia (2406 $\left.17^{\prime \prime S} 120^{\circ} 19^{\prime} 30^{\prime \prime E}\right)$. Liver sample preserved in $-75^{\circ} \mathrm{C}$ ultrafreeze at W.A. Museum.

\section{Paratypes}

Sex indicated in brackets.

Western Australia: NTM 17987 (M) Sandfire Flat (19 $\left.47^{\prime} \mathrm{S} 121^{\circ} 09^{\prime} \mathrm{E}\right) ; 45809-10$ (both M) Wallal Downs Homestead (19 $\left.47^{\prime} \mathrm{S} 120^{\circ} 38^{\prime} \mathrm{E}\right) ; 63313$ (M) Djaluwon Creek (20²0'S 127 26'E); 64001 (M) Anketell Ridge $\left(20^{\circ} 24^{\prime} \mathrm{S} 122^{\circ} 07^{\prime} \mathrm{E}\right) ; 64097$ (F) Staffords Bore $\left(20^{\circ} 21^{\prime} \mathrm{S} 127^{\circ} 24^{\prime} \mathrm{E}\right) ; 64143$ (F) Breaden Pool (20 $\left.15^{\circ} \mathrm{S} 126^{\circ} 34^{\prime} \mathrm{E}\right) ; 64186$ (F) $1 \mathrm{~km} \mathrm{~S}$ Waddawalla Well (21 $\left.41^{\prime} \mathrm{S} 125^{\circ} 46^{\prime} \mathrm{E}\right) ; 75798$ (F) Dragon Tree Soak (19 $\left.39^{\circ} \mathrm{S} 123^{\circ} 23^{\prime} \mathrm{E}\right) ; 75830$ (M) Anna Plains Homestead (19 $\left.15^{\prime} \mathrm{S} 121^{\circ} 29^{\prime} \mathrm{E}\right) ; 87007$ (F) Sandfire Roadhouse (19 $\left.46^{\circ} \mathrm{S} 121^{\circ} 06^{\prime} \mathrm{E}\right) ; 87353$ (M) $3 \mathrm{~km}$ SE Wallal Downs Homestead (19 $47^{\prime} \mathrm{S}$ $\left.120^{\circ} 40^{\prime \prime} \mathrm{E}\right) ; 88535-41$ (M, F, F, F, M, F, F) $55 \mathrm{~km} \mathrm{~S}$ Anna Plains Homestead (19 $\left.44^{\prime} \mathrm{S} 121^{\circ} 28^{\prime} \mathrm{E}\right) ; 94757$, 94776-77 (F, M) $80 \mathrm{~km} \mathrm{~S}$ Telfer Mine $\left(22^{\circ} 20^{\prime} 12^{\prime \prime} \mathrm{S}\right.$ $122^{\circ} 02^{\prime 26}$ "E); AM 100853, 101548 (both M) $6.6 \mathrm{~km}$ N Sandfire Roadhouse (19 $\left.19^{\prime} \mathrm{S} 121^{\circ} 16^{\prime} \mathrm{E}\right) ; 102650$ (M) Cooma 5, Little Sandy Desert (2406 $41^{\prime \prime S}$ $\left.120^{\circ} 19^{\prime} 10^{\prime \prime} \mathrm{E}\right) ; 108477$ (M) $18 \mathrm{~km}$ S Lake Hancock

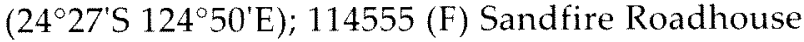
(1946'S $\left.121^{\circ} 06^{\prime} \mathrm{E}\right) ; 126496(\mathrm{M}), 126498$ (M) Gibson Desert Nature Reserve (244ㄴ $\left.124^{\circ} 52^{\prime} \mathrm{E}\right) ; 132802$ Warri Airstrip (24 $\left.15^{\prime} \mathrm{S} 124^{\circ} 24^{\prime} \mathrm{E}\right) ; 139089$ (M) Mandora Station (19 $\left.45^{\prime} 16^{\prime \prime} \mathrm{S} 121^{\circ} 26^{\prime} 59^{\prime \prime} \mathrm{E}\right) ; 140442$

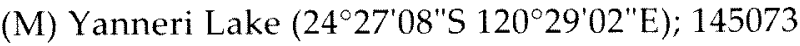
(M) Officer Basin area $\left(26^{\circ} 55^{\prime} 58^{\prime \prime} \mathrm{S} 125^{\circ} 16^{\prime} 44^{\prime \prime} \mathrm{E}\right)$; 151252 (F) Townsend Ridges (26 $20^{\prime} 25^{\prime \prime} \mathrm{S}$ $\left.126^{\circ} 56^{\prime 2} 6^{\prime \prime} \mathrm{E}\right)$. Northern Territory: NTM 14901 (F) $12 \mathrm{~km}$ SW Sangsters Bore (20 52'S 130 16'E); NTM 15038 (M) Uluru National Park (25⒉'S $\left.131^{\circ} 01^{\prime} \mathrm{E}\right)$; NTM R15138 (M), NTM 15144 (M), NTM 15146 (F), NTM 15151 (M) $12 \mathrm{~km}$ SW Sangsters Bore (205' $\left.130^{\circ} 16^{\prime} \mathrm{E}\right) ; \mathrm{NTM} 15230$ (M) $17 \mathrm{~km} \mathrm{~W}$ Sangsters Bore $\left(20^{\circ} 48^{\prime} \mathrm{S} 130^{\circ} 14^{\prime} \mathrm{E}\right)$; NTM 15501 (M) Uluru National Park (25⒉S $\left.131^{\circ} 01^{\prime} \mathrm{E}\right)$; NTM 20250 (M) Sangsters Bore (20 51'09"S $130^{\circ} 23^{\prime} 09^{\prime \prime E}$ ); NTM 26789 Henbury (24⒊'S 133 $30^{\prime} \mathrm{E}$ ); NTM 32301 (M) $10 \mathrm{~km}$ WSW Sangsters Bore $\left(20^{\circ} 44^{\prime} \mathrm{S} 130^{\circ} 16^{\prime} \mathrm{E}\right)$; NTM 34489 (F) Ayers Rock ( $\left.25^{\circ} 20^{\prime} S 131^{\circ} 01^{\prime} \mathrm{E}\right)$. South Australia: SAM 48671 (M) $9.3 \mathrm{~km}$ NNW Cheeseman Peak (27\%19'46"S 130 17'36"E); SAM 59561 (F) $3.3 \mathrm{~km} \mathrm{~W}$ Mount Holder, Birksgate Range $\left(27^{\circ} 08^{\prime} 43^{\prime \prime} \mathrm{S}\right.$ 129 39'51"E). 


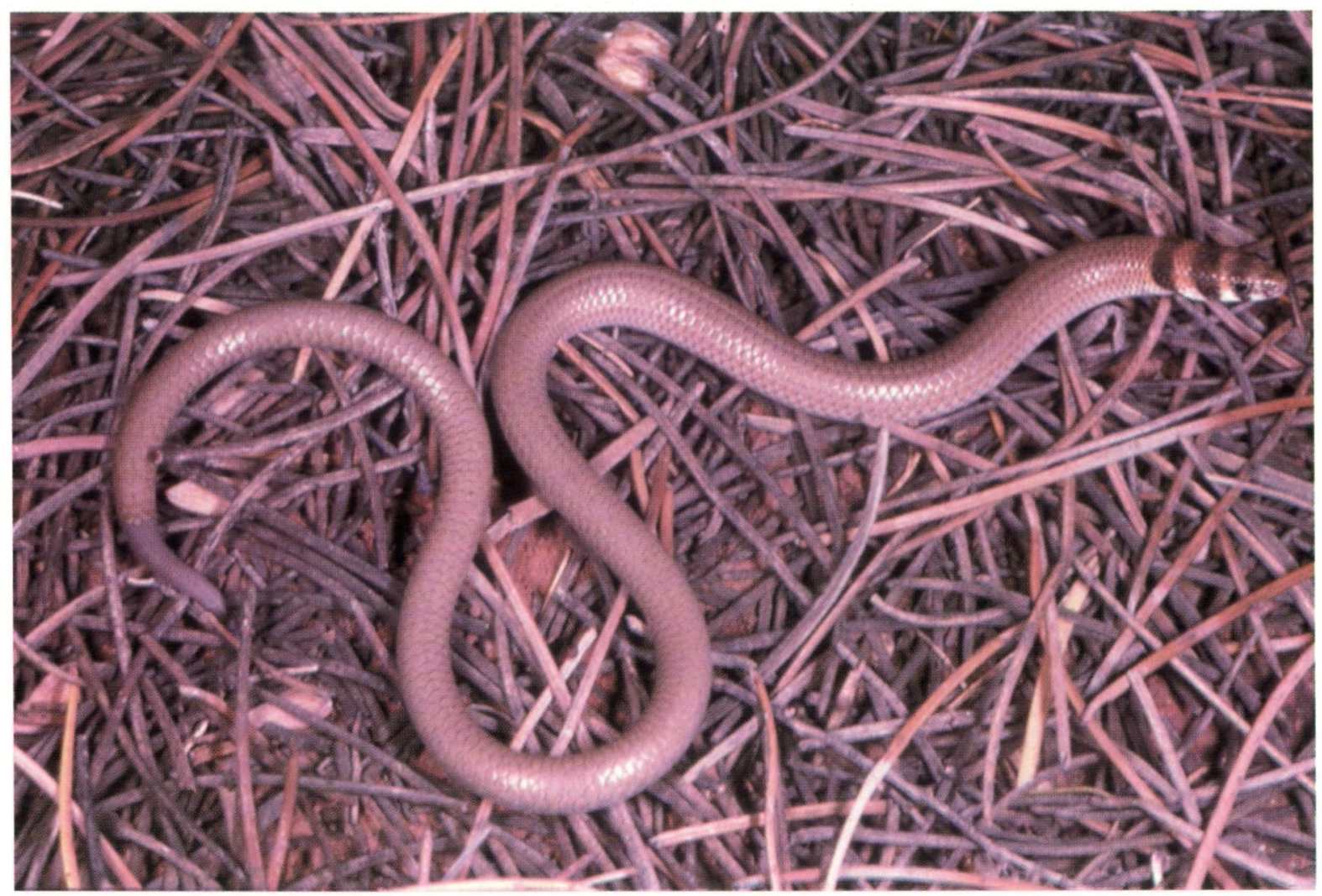

Figure 10 Holotype (102657) of Delma desmosa, photographed in life (B. Maryan).

\section{Diagnosis}

A moderately small, stout species of Delma (SVL up to $90 \mathrm{~mm}$ ) with modally 16 midbody scales, two pairs of supranasals and distinctive dark dorsal head markings present throughout life (any ontogenetic fading is restricted to markings forward of the eyes).

\section{Description}

Rostral with obtuse apex, penetrating between rostral supranasals; two pairs of supranasals, caudal pair much larger; rostral supranasals in moderate contact with first supralabial and caudal supranasals in point contact or only narrowly separated from the nostril; postnasal single; loreals 3-9, subequal; suboculars 3-4; supraciliaries 5, fifth much larger; supraoculars 2, second wider than first; supralabials 5-6, third typically elongate and positioned below eye (rarely, fourth is below eye); posteriormost supralabial much smaller; infralabials 4 (rarely 5), third elongate; occipital present; upper temporals 2 .

General form of head and details of scalation illustrated in Figure 11. Midbody scale rows 16; transversely enlarged ventral scales 48-59; hindlimb scales 8-10.

Morphological Variation: 75798 and 132802 have third supralabial divided on left side; 94757 has this scale divided on both sides. The location of accessory supralabial suture (e.g., anterior, centre or posterior) determines whether it is the third or fourth that is positioned below the eye.

64186 has third infralabial divided on right side; 114555 has this scale divided on both sides.

64097 has second supraocular fused with fourth supraciliary on both sides.

63313 has an upper loreal that is interposed between first and second loreals and contacts second supralabial on both sides.

88539 has supraoculars fused into one scale on right side.

NTM 15146 has a small scale interposed between caudal pair of supranasals and rostral supranasals divided into two scales on right side.

AM 100583 has first supraciliary fused with an upper loreal on right side.

AM 101548 has three small scales interposed between third and fourth supraciliary on right side.

\section{Colouration and patterning}

In preservative, upper and lateral surface grey to greyish brown merging with light brown on tail (particularly regenerated portion). Irregular black smudging on dorsal scales in some individuals (e.g., $64186,88537,15038,15151,15501)$. Lateral scales on forebody are plain. Lower surface immaculate white.

Head of juveniles and adults typically with three to four dark brown to black dorsal to lateral bands, that narrow as they descend and terminate obtusely 

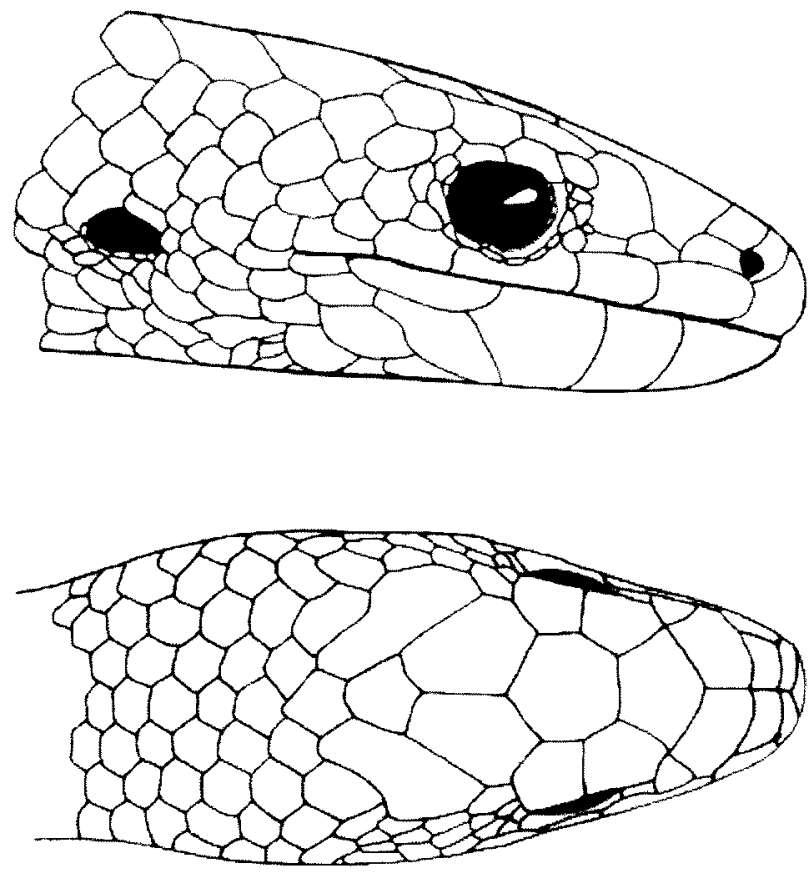

Figure 11 Head scalation of Delma desmosa holotype (102657) in lateral (top) and dorsal (bottom) views.

on mental scale, on infralabials and behind the ear. Dark head bands are most intense on immature specimens (Figure 12A) but remain well-defined in most adults (Figure 12C; ontogenetic fading is a common occurrence in other Delma spp.). Interspaces between dark bands light brown, greyish to white and usually widest on back of head through ear and neck. Supralabials and infralabials whitish in between dark bands. Below the mouth, bands are typically centred on suture between mental and first infralabial, and on suture between second and third infralabials; suture between first and second infralabials is invariably clear; occasionally, the first dark head band completely covers the first infralabial but not its anterior suture (e.g., 140442).

In adults that show signs of ontogenetic fading of the head pattern (Figure 12B), the first band (on snout and lores) and second band (over eyes) typically become diffuse and merge to form a cream to light brown colour forward of eyes. The broader third and fourth dark bands (forward of and behind ears, respectively) are persistent in adults and are rarely diffuse or broken. In some individuals (e.g., 15038,34489 , 88537) coalescent dark smudges positioned transversely across forebody are suggestive of a fifth dark band. Adult specimens of $D$. desmosa with pronounced ontogenetic fading come from localities spread across the western half of the range of the species, including localities in the Great Sandy Desert (e.g., 64097, 64143, 75830) that are remote from the range of $D$. pax in the Pilbara region. The wide geographic distribution of these individuals make it unlikely that they are the product of introgression between $D$. pax and $D$. desmosa.

In life, some adults have pale orange-brown interspaces between the dark bands; this pigment is lost in preservative.

\section{Details of Holotype}

Snout-vent length $(\mathrm{mm}) 87$; tail 163; loreals 8 on left side, 9 on right; midbody scale rows 16; ventrals 59; hindlimb scales 9. Greyish brown upper and lateral surface.

Indication of four dark brown head bands as follows: first on lores is diffuse and terminates as smudge on first infralabial; second terminates on suture between second and third infralabial, leaving preceding suture clear white; third and fourth bands are dark brown and well-defined.

\section{Etymology}

From the Greek desmos, a chain, tie, or band, in specific reference to the distinctive and persistent dorsal head bands of this species.

\section{Distribution and sympatry}

Widespread in arid desert regions of western and central Australia (Figure 8) extending west to the vicinity of the 80 mile beach (Anna Plains and Wallal Downs Stations), south to the Little Sandy Desert and Officer Basin area and east through the Great Sandy, Tanami and Great Victoria Deserts into central Northern Territory (Sangsters Bore, Uluru National Park and Henbury) and northwestern South Australia (Cheeseman Peak).

The geographic distributions of $D$. desmosa and D. pax appear to be allopatric (Figure 8). Currently the two species are known to occur within $90 \mathrm{~km}$ of each other (e.g., 102650, 102657 from Little Sandy Desert versus 125452 from $30 \mathrm{~km}$ E Newman, respectively). Specimens from these proximate localities do not show any admixture of characters as might be expected if significant levels of gene flow were occurring across a contact zone or step cline.

Five Delma species have geographic distributions that overlap that of $D$. desmosa: $D$. borea, $D$. butleri, $D$. haroldi, D. nasuta and D. tincta. Among these species, the greatest morphological similarity occurs between $D$. desmosa and $D$. borea (see below). The distributions of $D$. borea and $D$. desmosa are broadly overlapping in the south Kimberley, southern Northern Territory and northwestern South Australia (Figures 8, 15) but there are few known instances of actual sympatry. Recent collections by P. Kendrick of the Department of Environment and Conservation have extended the mainland $W$.A. range of $D$. borea south to the vicinity of Mandora (e.g., 112725-26, 139058, 


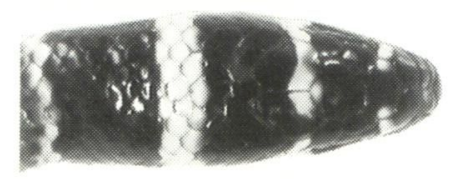

(A) Immature D. desmosa
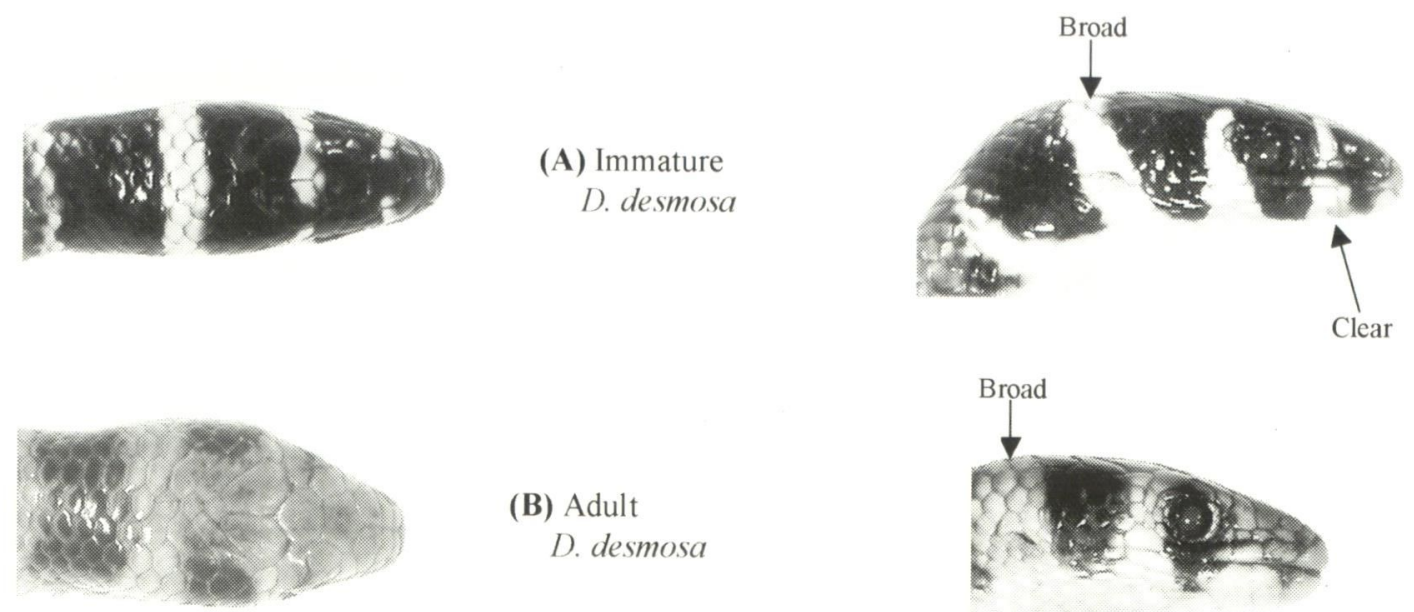

(B) Adult D. desmosa
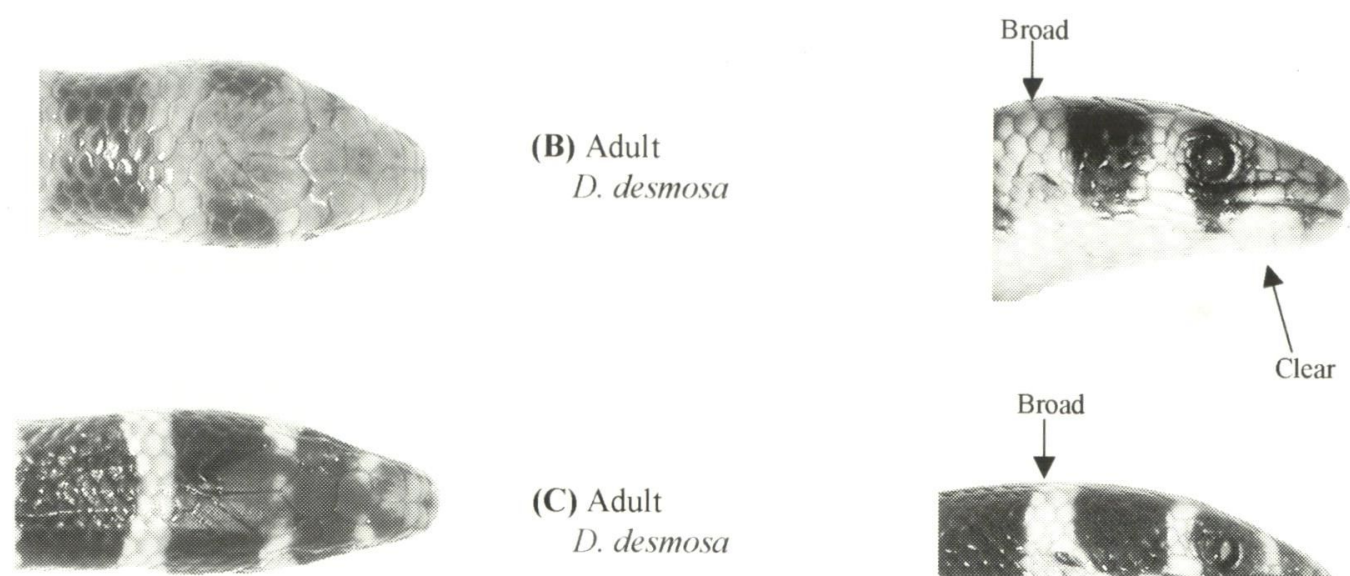

(C) Adult

D. desmosa
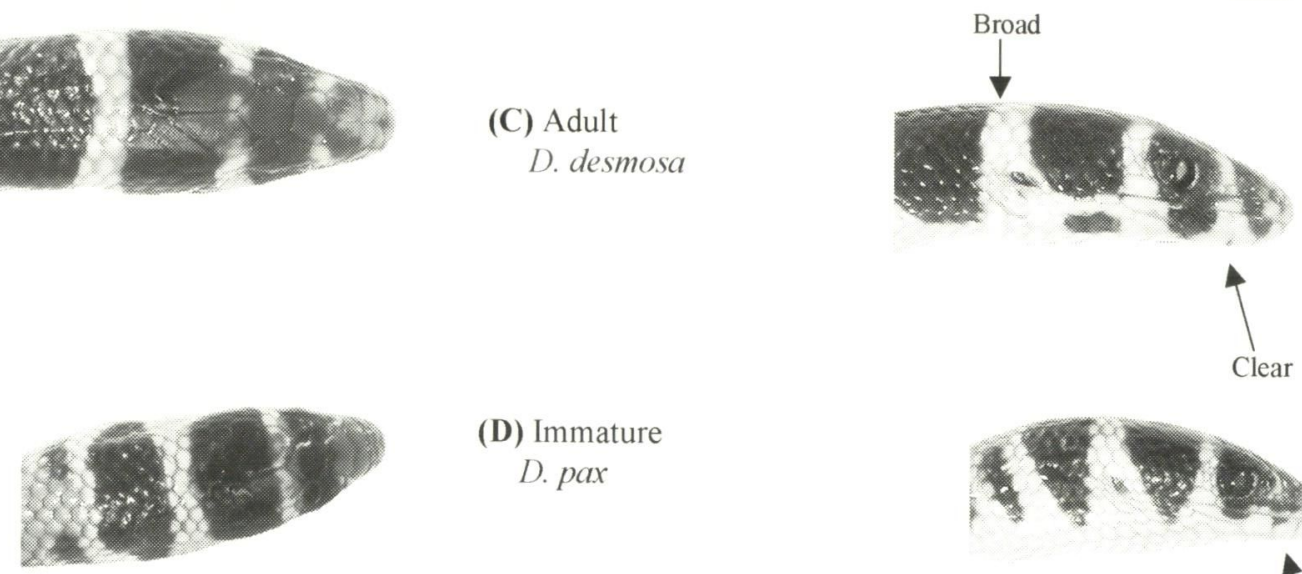

(D) Immature D. $p a x$

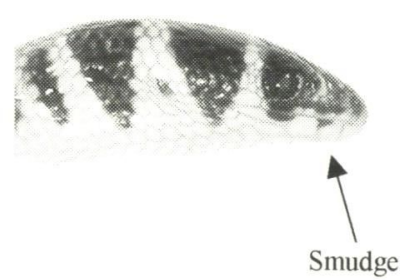

(E) Sub-adult D. pax
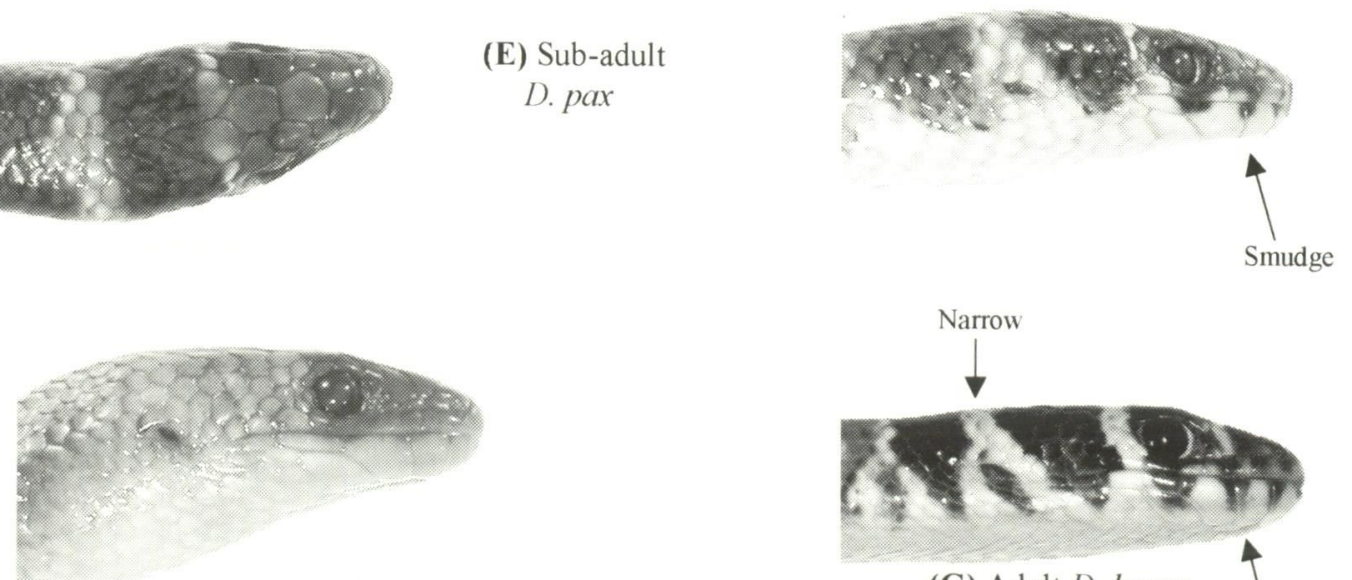

(F) Adult D. pax

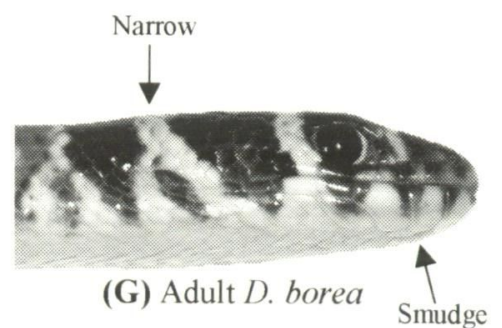

Figure 12 Head patterning of A, D. desmosa, immature from Townsend Ridges (151252), B, D. desmosa adult with weak bands forward of eyes from Staffords Bore (64097), C, D. desmosa adult with strong bands from Ayers Rock, Northern Territory (NTM 34489), D, D. pax immature from 82km E Port Hedland (140396), E, D. pax sub-adult with fading bands from DeGrey River Station (132549) and arrows indicating clear or pigmented suture and broad auricular band in D. desmosa, all shown in dorsal and lateral views and F, D. pax adult from Potter Island (139353) showing complete lack of head patterning, G, D. borea adult with strong bands from Mitchell Plateau (77201) and arrows indicating pigmented suture and narrow auricular band, shown in lateral views. 
139062-63) where D. desmosa (e.g., 139089) is also recorded. Currently this represents the only known instance of sympatry for these two species in Western Australia. However, the single specimen of D. desmosa was obtained on the crest of a Triodiacovered sandridge, while specimens of $D$. borea came from the edge of a spring with Melaleuca leucadendra on clayey soil. Records of $D$. desmosa and $D$. borea from the arid southern Northern Territory and northwestern South Australia also tend to come from different localities. Systematic faunal surveys have only recently recorded $D$. borea from northwestern South Australia (Robinson et al. 2003) and the Uluru National Park (McAlpin 2005). Generally, D. borea prefers areas of stony or heavy soils with Triodia and tussock grasses or savanna woodland with grass/leaf litter (B. Maryan, personal observation) and appears to not occupy Triodia on sandplains (Kluge 1974: 82), the preferred habitat of $D$. desmosa. The available information thus suggests a degree of habitat partitioning between $D$. desmosa and $D$. borea in areas where their ranges interdigitate.

In Western Australia, other recorded instances of sympatry involving $D$. desmosa include $D$. haroldi and $D$. nasuta in the Little Sandy Desert and Central Ranges (B. Maryan and P. Doughty, personal observation) and D. butleri has been collected from the Officer Basin area, where D. desmosa (e.g., 145073 ) is also recorded. In the Northern Territory, Reid et al. (1993) records both $D$. butleri and $D$. nasuta from the same survey site as 'D. pax' $(=D$. desmosa) in Uluru National Park.

\section{Comparison with other species}

Delma desmosa will be compared first with $D$. pax and $D$. borea, two species with which it has previously been confused, and then with other regionally sympatric Delma spp.

Delma pax and $D$. desmosa are similar in body proportions (Table 1) and agree in most details of head and body scalation. The head pattern of juveniles is also similar, consisting of four 'opalescent' black bands and pale interspaces (Figure 12A, D), but the fate of this pattern is very different. In $D$. desmosa the bands are retained through to adult life (Figures 10, 12C) while in $D$. pax they undergo pronounced ontogenetic fading (Figure 12E) such that adults typically lack any head pattern (Figures 12F, 14). Another difference in head pattern concerns the ventral extent of the anterior dark head bands; in D. pax the first (on snout) and second (through eyes) bands typically terminate on the infralabials, while in $D$. desmosa they extend onto the mental scale and below the infralabials, and are visible in ventral view. In addition, the first dark head band on the snout in $D$. pax is regularly weak or absent and usually distinct in D. desmosa. Immature specimens of D. pax typically have three dark brown smudges on the lower lip, situated over the sutures between the mental and anterior two infralabial scales (Figure 12D-E). In $D$. desmosa the suture between the first and second infralabial typically is unpigmented (Figure 12A-C).

On meristic and mensural data, D. desmosa averages slightly smaller than $D$. pax for most measurements (Table 1). This contrast is particularly striking for males, reflecting more pronounced sexual dimorphism in $D$. pax than $D$. desmosa (Table 1). In both sexes the mean ventral scale count is significantly lower in $D$. desmosa than in D. pax (Table 4).

Delma borea is similar to $D$. desmosa in overall body size but has shorter hindlimb flaps and a significantly higher average number of ventral scales in both sexes (Tables 1,4). The two species are readily distinguished by head pattern. Delma borea has a pale inter-band on the back of head which narrows dorsally but broadens or 'forks' at the ear aperture (Figure 12G). In D. desmosa the auricular inter-band typically is of even width or only slightly broader laterally (Figure 12A-C). Most $D$. borea also have some variegated ventrolateral scales on the forebody. These scales are unpatterned in $D$. desmosa. Delma borea typically have the fourth supralabial positioned below the eye (typically the third in D. desmosa).

Delma borea and D. pax both have three dark brown smudges situated between the nostril and the eye, and positioned over the mental and infralabial scale sutures (Figure 12D-E, G). These smudges are absent only in some adults devoid of any head pattern (Figure 12F). In contrast, the suture between the first and second infralabial typically is clear in $D$. desmosa; in occasional specimens (e.g., 140442) the first head band completely covers the upper portion of the first infralabial scale.

Apart from $D$. borea, the only Delma species with distributions overlapping that of $D$. desmosa are $D$. butleri, $D$. haroldi, $D$. nasuta and $D$. tincta. $D$. desmosa is easily distinguished from the first three by having dark dorsal head markings and from $D$. tincta by the presence of two pairs of supranasal scales (one pair in D. tincta), a higher midbody scale row count (modally 16 versus 14) and unpatterned ventrolateral scales on the forebody.

\section{Habitat}

The holotype was raked (using a 3-prong cultivator) from Eucalyptus chippendalei leaf litter in dune swale on red sand with groundcover of Thryptomene and Triodia (Figure 13). Notes accompanying some Western Australian paratypes include "raked from dead Triodia clumps and shrubs on crest of sandridges" (e.g., 88535-41); "pittrapped on claypan with Acacia over mixed grasses 


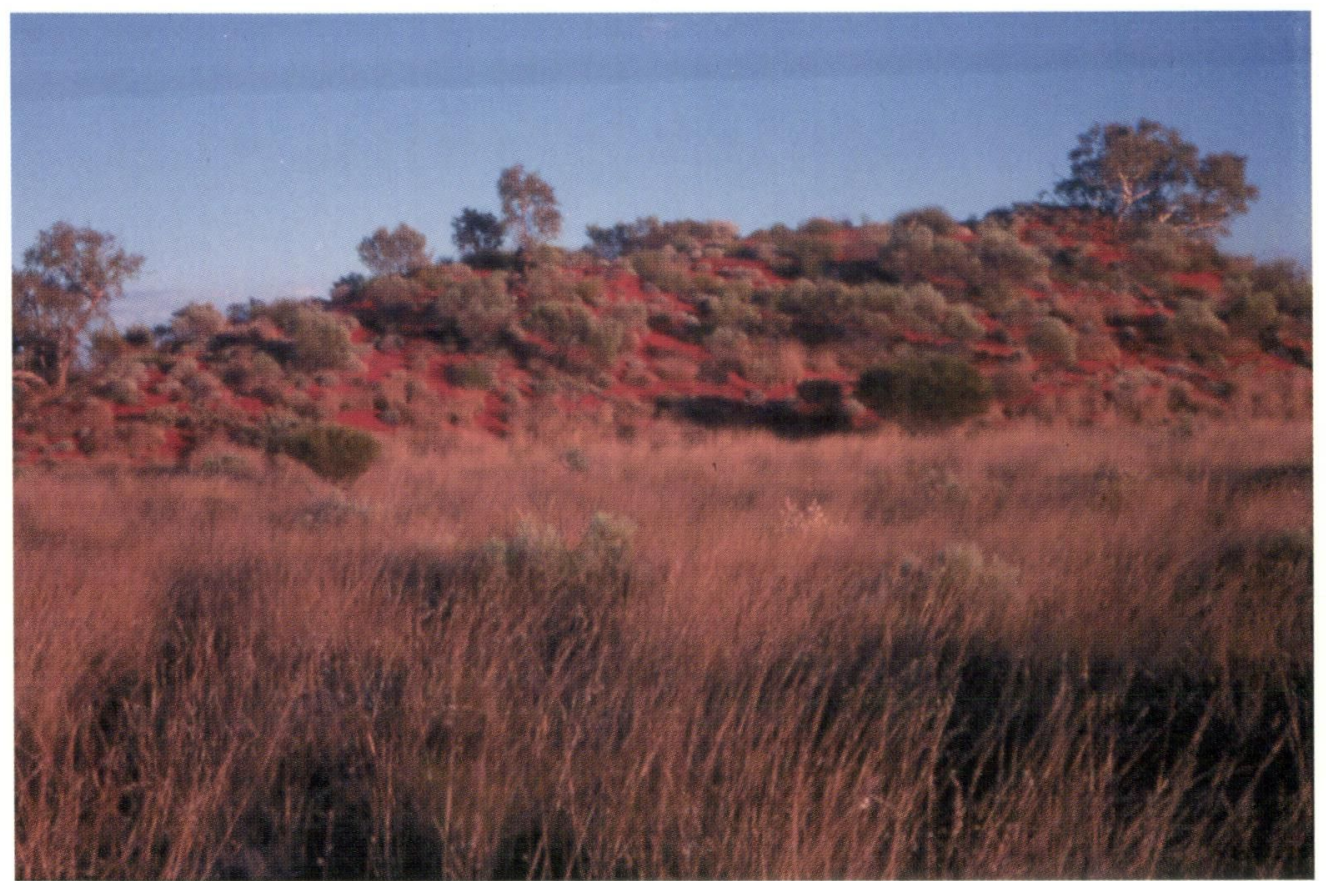

Figure 13 Triodia sandplain in swale with red sand dune covered with Eucalyptus chippendalei, Acacia and Triodia at the Little Sandy Desert WA, the habitat for Delma desmosa (B. Maryan).

and samphire" (e.g., 75798); "along minor drainage lines with fringing Eucalyptus" (e.g., 63313, 9477677) and "active at night on road in sandplain with sparse Acacia over Triodia" (e.g., 114555). Habitat details for paratypes from Northern Territory and northwestern South Australia are "pit-trapped in Triodia grassland" (e.g., 14901, 15038, 15138, 15144, 15146, 15151, 15230, 15501, 20250); "mulga woodland over bluebush and tussock grasses on sandplain" (e.g., 48671) and "under loose stones on rocky hillside" (e.g., 59561).

\section{Remarks}

The specific characteristics of $D$. desmosa have created prior confusion between $D$. borea and $D$. pax. Shea (1991) drew attention to this problem by mentioning a specimen from Ayers Rock (NTM 1319; renumbered 34489) that shares $D$. borea and $D$. pax scalation characters. This specimen is herein referred to $D$. desmosa (Figure 12C). Systematic faunal surveys by Reid et al. (1993) and McAlpin (2005) also mentioned problems with identification and variously assigning a Delma sp. to $D$. borea or $D$. tincta in previous reports, but identified by them as ' $D$. pax'. Their accounts of ' $D$. pax' from Uluru National Park are most likely based on individuals of $D$. desmosa.

Ehmann (1992: 94) and Reid et al. (1993: 49) illustrate $D$. desmosa from the Great Sandy Desert, Western Australia and from Uluru National Park, Northern Territory respectively; in both publications the specimens are identified as $D$. pax.

\section{Delma pax Kluge, 1974}

Figure 14

Delma pax Kluge (1974: 113-117). 14804 in the Western Australian Museum, an adult female collected on 21 May 1961 by G.M. Storr at Jones River, Western Australia (205'ㅇ, $\left.117^{\circ} 23^{\prime} \mathrm{E}\right)$.

\section{Revised diagnosis}

A moderately small, stout species of Delma (SVL up to $98 \mathrm{~mm}$ ) with modally 16 midbody scales, two pairs of supranasals, and a plain adult colouration due to pronounced ontogenetic fading of dorsal head markings (markings prominent in juveniles).

\section{Description}

Rostral with obtuse apex, penetrating between rostral supranasals; two pairs of supranasals, caudal pair much larger; rostral supranasals in moderate contact with first supralabial and caudal supranasals in point contact or only narrowly separated from the nostril; postnasal single; loreals 4-10, subequal; suboculars 2-4; supraciliaries 5 (rarely 4), fifth much larger; supraoculars 2, second wider than first; supralabials 5-6, third typically elongate and positioned below eye (occasionally, fourth is below eye), posteriormost supralabial much smaller; infralabials 4 , third elongate; occipital present; upper temporals 2 . Midbody scale rows usually 16 [ 14 in $12.4 \%$ of specimens; 18 in one specimen (119045; from Port Hedland)]; specimens with 14 midbody scale rows are Bohemia 


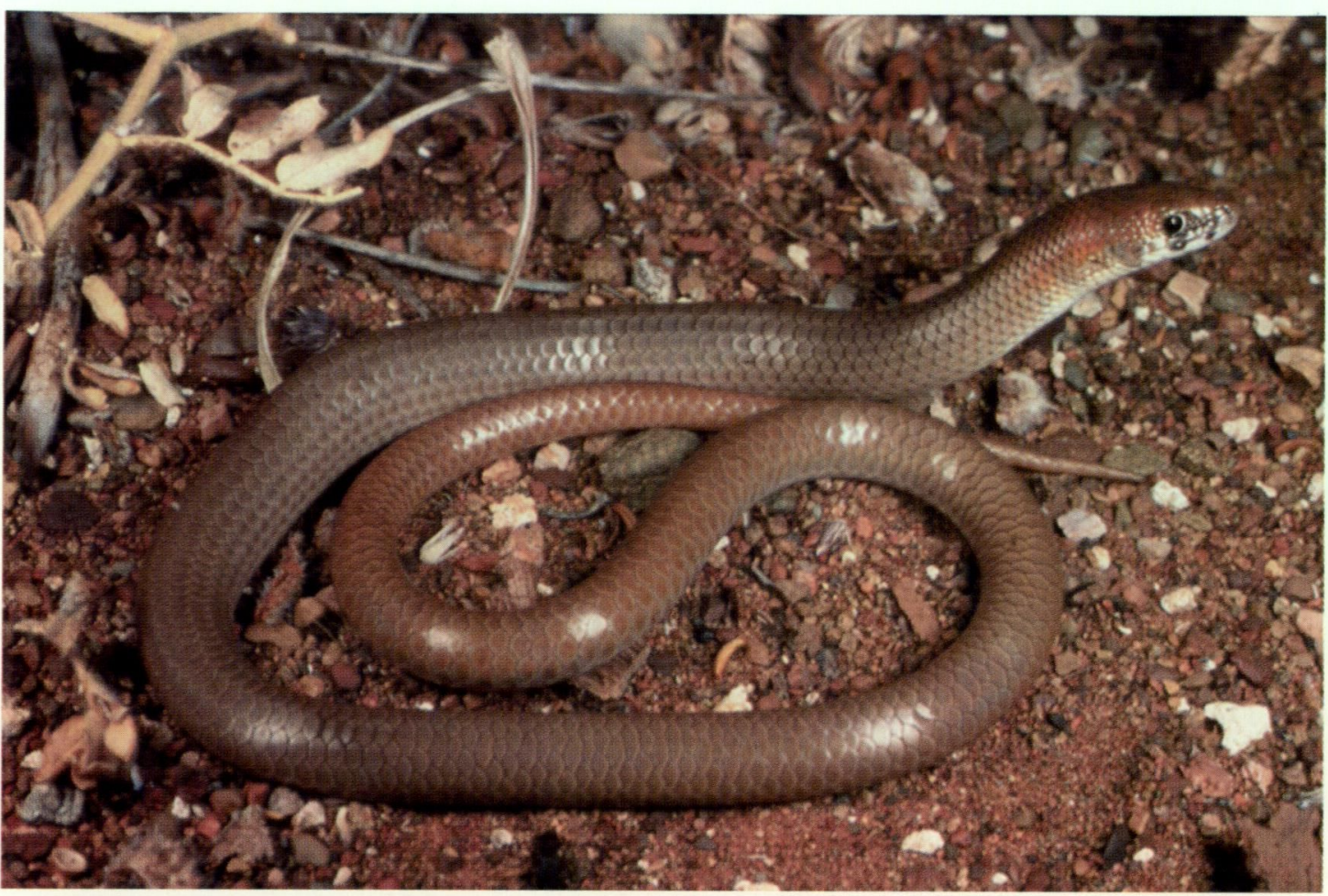

Figure 14 Adult Delma pax from Meentheena, photographed in life (B. Maryan).

scattered throughout the range of $D$. pax and often come from the same localities as specimens with 16 midbody scale rows. Storr et al. (1990) state that $D$. pax has 'rarely 17 ' midbody scale rows but without citing specimen details. Transversely enlarged ventral scales 50-60; hindlimb scales 8-10.

Morphological Variation: Kluge (1974) examined $16 D$. pax and recorded only a single specimen with the fourth supralabial below the eye on one side only (SAM 3445 from Pilgangoora Well). Our examination of a further 97 specimens found this condition in unilateral or bilateral states in $20 \%$ of individuals, as follows: fourth supralabial below eye on both sides in 73146, 102137, 113387, 119045046, 129930, 132657, 135919, 139294, 140396, 145680 and 146649; fourth supralabial below eye on right side only in 127829, 135320, 139353 and 146591; on left side only in 9943, 73841 and 129658.

Other variants are:

9946 has fusion of second and third supraciliaries (total 4) on both sides; 132606 has same condition on right side only.

81390 has rostral contacting caudal supranasals and thus separating rostral supranasals; 129930 has small scale interposed between rostral supranasals.

119045 has two upper loreal scales on right side.

145748 has rostral and caudal supranasals fused on right side.

\section{Colouration and patterning}

In preservative, upper and lateral surface brown to reddish brown merging into pale grey on lower lateral surfaces. Lateral scales on forebody are plain. Lower surface white and unpatterned.

Head of juveniles typically with strong pattern of transverse bands (Figure 12D). Intensity of bands diminishes with increasing body size (= age) such that head and neck of large adults are typically light to reddish brown and unpatterned (Figures 12F, 14). Where traces of pattern are retained (e.g., $129658,132548,139170,140021)$, this consists of very diffuse pale brown spaces ('ghosting' of bands) between the ears and behind the eyes.

Head pattern of immature specimens consists of three to four brown to blackish brown bands that narrow as they descend and terminate obtusely on the infralabials and behind the ear. The first band (on snout) is variably developed and may be absent, even on juveniles. The bands crossing the back of the head and the neck are broader and more distinct and the pale interbands are typically of even width, without any lateral widening. The interband spaces are pale reddish brown in life but this typically fades to a lighter brown or a greyish-white (e.g., 140396) in preservative. A narrow and faint pale band is usually present on the neck behind the posteriormost dark band; this is, occasionally followed on the side of the neck by a narrow dark band (e.g., 140396).

Supralabials and infralabials of juveniles whitish in between dark bands. Dark bands extend below mouth and terminate on suture lines between mental and first infralabial scales, between second and third infralabials, and between third and fourth 
infralabials. These suture line smudges undergo ontogenetic fading in concert with the general head pattern.

\section{Distribution and sympatry}

Widespread throughout Pilbara region of Western Australia (Figure 8) with southerly extension to northern Gascoyne at Turee Creek, extending north to DeGrey River Station, east to Carawine Gorge and $30 \mathrm{~km}$ east of New man and southwest to Mount Minnie and Cane River Stations. Also occurs on Potter Island off Pilbara coast. Endemic to Western Australia.

As noted earlier, D. pax appears to be allopatric with respect to the closely related $D$. desmosa (Figure 8). However, D. pax is regionally sympatric in the Pilbara region with $D$. butleri, $D$. haroldi, $D$. elegans Kluge, 1974, D. nasuta and D. tincta. Recorded instances of sympatry involving $D$. pax include $D$. haroldi, $D$. nasuta and $D$. tincta from multiple localities throughout the Pilbara region. For instance, in the vicinity of Port Hedland, D. pax, $D$. haroldi and $D$. tincta have all been observed crossing the same section of sealed road at night. Delma pax and D. nasuta were observed together in the same context in the vicinity of Newman (B. Maryan and $\mathrm{B}$. Bush, personal observation). Delma pax also has been recorded with $D$. elegans from several localities including Meentheena and Pannawonica.

\section{Comparison with other species}

Delma pax will be compared first with $D$. borea, and then with other regionally sympatric Delma spp. For comparison with $D$. desmosa see the preceding account.

Both sexes of $D$. pax average larger than $D$. borea in almost all linear measurements (Tables 1, 4), while average ventral scale counts are significantly higher in female $D$. pax than female $D$. borea but not in males. Body pattern in D. pax features plain ventrolateral scales on the forebody, whereas $D$. borea typically has variegated scales in this area. Specimens of $D$. pax that retain traces of the immature head pattern (Figure 12E) are distinguished from $D$. borea by having a band on back of head that is slightly broader and of more even width (in D. borea the auricular band is narrower mid-dorsally but broadens laterally, often 'forking' at the ear aperture; Figure 12G). Delma pax typically have the third supralabial positioned below the eye (typically the fourth in D. borea).

As indicated above, five other Delma species occur in regional sympatry with $D$. pax (D. butleri, $D$. haroldi, D. elegans, D. nasuta and $D$. tincta). The relatively inornate $D$. butleri bears a superficial resemblance to adult $D$. pax but differs in having more complex patterning on the lips, side of head and neck (variably marked with brown and white spots, blotches or vertical streaks). Delma haroldi is more distinct with narrow wavy pale bands (but no dark bands) across the head and neck. Delma elegans has five or six dark head bands that descend obliquely forward and also has higher midbody scale row counts (modally 18 versus 16). Delma nasuta has a longer, sharper snout with a spotted or reticulated pattern on the dorsal and ventral surfaces. Finally, D. tincta has one pair of supranasals (versus two in D. pax), lower midbody scale row counts (modally 14 versus 16), fewer loreal scales on average (Table 1) and variegated scales on the lateral forebody (versus plain scales in D. pax). Delma tincta generally averages smaller than D. pax in linear dimensions (Table 1).

\section{Habitat}

Delma pax occupies a variety of habitats in the Pilbara region including sandy riverside flats and stony slopes with heavy soils. It is most frequently obtained from Triodia clumps but also shelters in flood debris along dry watercourses. The species is often observed at night active on sealed roads ( $B$. Maryan, personal observation).

\section{Remarks}

Kluge (1974: 116-117) illustrates the head region of both immature and adult D. pax. Adult D. pax is illustrated by Wilson and Knowles (1988: 249), Storr et al. (1990: Plate 17.3), Cogger (2000: 290) and Wilson and Swan (2003: 117). Wilson and Swan (2003: 111) illustrate an immature D. pax (140396) from the Port Hedland district, mislabeled as $D$. borea.

\section{Remarks on the distribution of Delma borea}

The taxonomic changes proposed above also help clarify the species limits and geographic distribution of $D$. borea. As delimited here, $D$. borea in Western Australia is a moderately small, stout species of Delma (SVL up to $98 \mathrm{~mm}$ ) with modally 16 (rarely 17) midbody scales, two pairs of supranasals, the fourth supralabial scale positioned below the eye (unilaterally third supralabial below eye in two out of 114 specimens), and variegated ventrolateral scales on forebody. Juveniles possess well-defined dark head bands. Adults undergo ontogenetic fading to varying degree and usually possess indistinct pale brown bands on the head and neck. These morphological characteristics are consistent with previous accounts of D. borea in the more easterly parts of its range (Kluge 1974).

Figure 15 shows the distribution of $D$. borea in Australia, based on our reassessment of specimens in the collection of the Western Australian, Northern Territory and South Australian Museums. In Western Australia, this species ranges from the Kimberley southwest to Mandora inland of the 80 mile beach, and south to the Edgar Ranges, $25 \mathrm{~km} \mathrm{E}$ 
Downs and Denison Range. It is present on numerous islands off the Kimberley coast (Troughton, Naturalist, Coronation, Heywood, Sunday, Augustus, King Hall, Cockatoo and Koolan) and at least three islands off the Pilbara coast (Barrow, Hermite and Rosemary). It also occurs in the Northern Territory, western Queensland and northwestern South Australia (Kluge 1974; Shea 1987, 1991; Ingram and Raven 1991; Ehmann 2005). In the Northern Territory, $D$. borea is most common in the Top End, with the southernmost records at Wave Hill, Helen Springs and $50 \mathrm{~km} \mathrm{~S} \mathrm{MacArthur} \mathrm{River} \mathrm{camp} \mathrm{(Shea} \mathrm{1991);} \mathrm{it}$ appears to be sparsely distributed south of the $20^{\circ}$ parallel that includes its occurrence in northwestern South Australia on Aboriginal Lands (Ehmann 2005). Kluge's (1974: Figure 47) map for this species shows a record in northwestern South Australia but without an equivalent specimen listed under Paratypes; we assume that the map is in error.

Three specimens included by Kluge (1974: 192) within $D$. borea warrant special mention. Specimen 25201 from $32 \mathrm{~km}$ E Jiggalong was also mapped as D. borea by Storr et al. (1990) and further cited by
Shea (1991) as representing this taxon. This specimen is confirmed here as a member of the $D$. tincta group due to the presence of a enlarged upper temporal scale bordering each parietal. It differs from each of $D$. borea and from $D$. desmosa in being more slender bodied, and differs from $D$. desmosa in having more pronounced variegation of the ventrolateral scales on the forebody. In both of these respects, the specimen resembles $D$. tincta. However, it differs from $D$. tincta in having paired supranasals and 16 midbody scale rows, and in these respects, more closely resembles $D$. borea and $D$. desmosa. This specimen might represent an outlier of $D$. borea, a somewhat aberrant $D$. desmosa, or another, as yet unrecognized taxon.

Specimen SAM 5058 referred to $D$. borea also by Shea (1991) from the Warburton Range is similar in most respects to specimen 25201. The colour pattern is similar to both $D$. borea and $D$. tincta, most notably in the presence of variegated ventrolateral scales on the forebody. The specimen has two pairs of supranasal scales and the fourth supralabial positioned bilaterally below the eye, both features shared with typical D. borea. However, it is slender

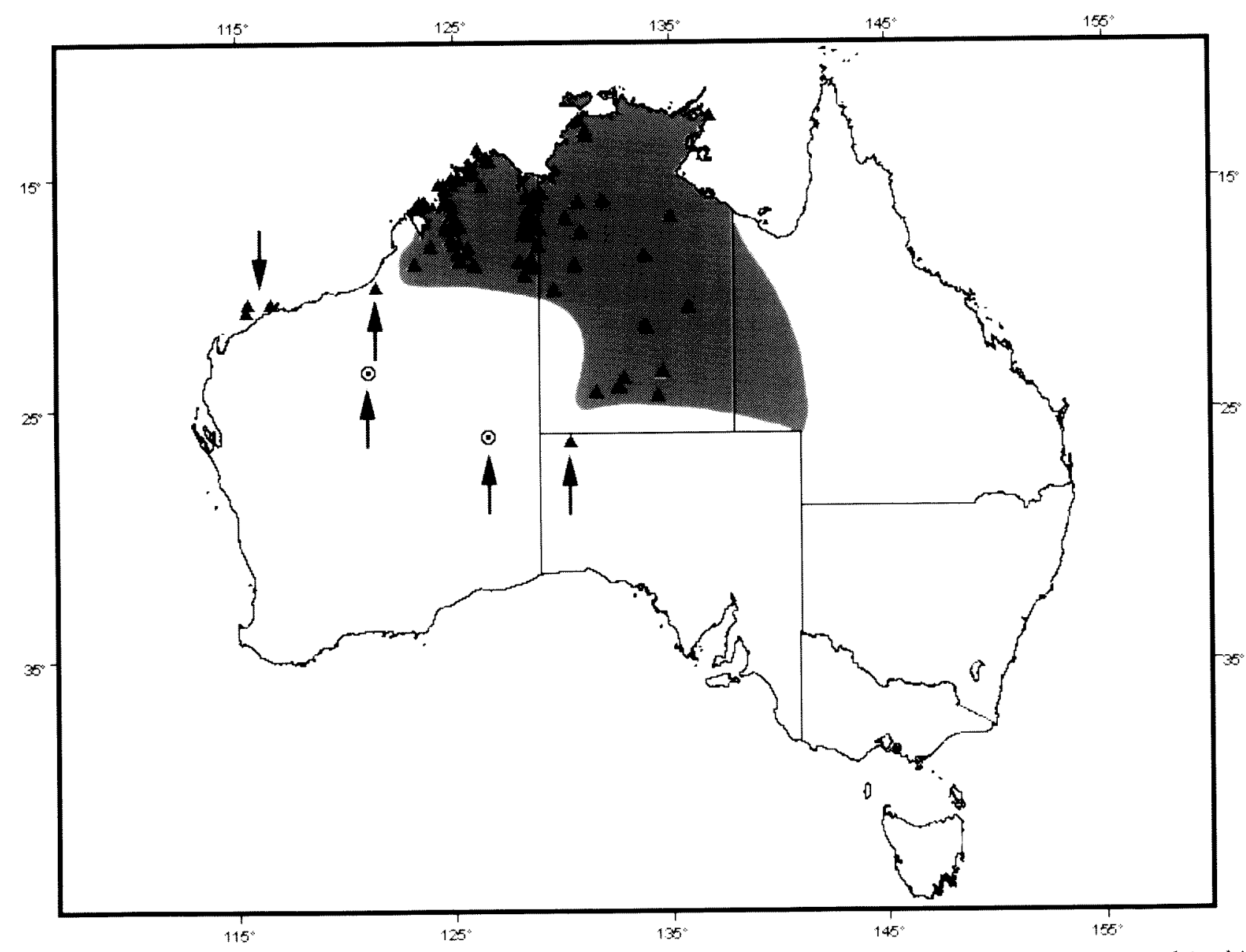

Figure 15 Map of Australia showing distribution of D. borea (shading) and location of specimens examined in this study (triangles). Arrows indicate outlier populations at Mandora, western Pilbara islands and northwestern South Australia and the two specimens (circles with cross) from $32 \mathrm{~km}$ E Jiggalong and Warburton Range that are regarded as $D$. sp. incertae sedis pending further field survey and analysis. 
bodied and has 14 midbody scales, more typical of $D$. tincta. The presence of variegated ventrolateral scales on the forebody and the absence of strong head patterning distinguish the specimen from regionally sympatric $D$. desmosa. The desert regions are poorly sampled for herpetofauna (How and Cowan 2006) and until further material is available, we recommend that the Warburton Range and Jiggalong populations be treated as Delma sp. incertae sedis.

Specimen SAM 4475 from Tambrey is listed twice by Kluge (1974: 192), once as a paratype of $D$. borea and again as a paratype of $D$. elegans. Advice from the South Australian Museum indicates that there have been no changes made in relation to this registration number which is currently attached to a paratype of $D$. elegans (M. Hutchinson, personal communication); the duplicate listing under $D$. borea is assumed to be an editorial error.

\section{DISCUSSION}

\section{Taxonomic diversity of the Delma tincta group}

The present study has identified two additional members of the Delma tincta group as defined by Shea (1991). Delma desmosa from the arid sand deserts of western and central Australia is a close relative of $D$. pax which is now recognized as endemic to the Pilbara region. The ranges of $D$. pax and $D$. desmosa appear to be allopatric or parapatric (current records suggest a gap of no more than $90 \mathrm{~km}$ between populations). These species are weakly differentiated genetically and they differ morphologically mainly in features of colouration (most notably the degree of ontogenetic fading of the juvenile head markings), and in the degree to which sexual dimorphism is expressed. However, the fact that an abrupt boundary is maintained between the two taxa over a very large distance around the periphery of the Pilbara uplands indicates that they represent discrete evolutionary lineages, each with its own set of ecophysiological requirements, and thus warrant specific recognition. Gene flow between the populations, if it occurs at all, is clearly limited and insufficient to influence the genetic or morphological characteristics of the spatially adjacent populations. Nevertheless, contact zones between $D$. pax and $D$. desmosa should be sought in which to investigate the nature and extent of genetic interactions between these taxa. Furthermore, ecological and behavioural comparisons of these closely related species might yield valuable insights into the adaptive significance of head patterning in Delma.

Delma tealei, an endemic of the Cape Range Peninsula, is most similar morphologically to $D$. borea and to a lesser extent, to $D$. tincta, all three taxa sharing the unusual characteristic of variegated scales on the ventrolateral forebody. The allozyme data suggest a possible sibling relationship between $D$. borea and $D$. tealei, and a more remote association with $D$. tincta. However, the level of divergence is much greater than that observed between $D$. pax and $D$. desmosa, and identifies $D$. tealei as a well established lineage within the $D$. tincta group.

\section{Biogeography of the Delma tincta group}

The $D$. tincta group as a whole has a 'Torresian' distribution (sensu Cogger and Heatwole 1981). This appears to be unique within the genus Delma, since other species groups recognized on morphological (Kluge 1974; Shea 1991) or molecular criteria (Jennings et al. 2003) have geographic distributions that either range across southern Australia (D. australis $+D$. torquata Kluge, 1974; $D$. fraseri $+D$. grayii; $D$. peterson $+D$. inornata), are confined to eastern Australia (D. impar $+D$. molleri $+D$. mitella Shea, 1987), or are centred on the arid inland region $(D$. butleri/D. haroldi $+D$. nasuta). With a total of five species, the $D$. tincta group is also the most speciose of the major intrageneric lineages identified to date. However, as noted above, this may reflect a lack of complete taxonomic discrimination in some other groups, most notably in the $D$. butleri/D. haroldi complex and in the $D$. australis group (Aplin and Smith 2001).

Within the Delma tincta group, the widely distributed $D$. tincta appears to be broadly sympatric with each of $D$. borea, $D$. pax and the two additional members described in this paper. Whether this entails instances of true syntopy is not known. However, in our view the likelihood of syntopy is enhanced by the unusual morphological characteristics of $D$. tincta within this group, in particular its relatively small adult size and slender build (as reflected by a reduced number of midbody scale rows). Delma tealei, which is at least regionally sympatric with $D$. tincta on the Cape Range Peninsula, shares several of these characteristics and it would be of great interest to know more about the ecological interaction between these species.

Delma pax and $D$. desmosa have allopatric or parapatric distributions, the former confined to the Pilbara region, and the latter found in the surrounding sandy deserts and extending east into the central Australian deserts. Along its northern margin, the range of $D$. desmosa appears to interdigitate with that of $D$. borea but with no records of syntopy. These taxa differ in relatively subtle aspects of body colouration, meristics and in relative hindlimb flap length, and they may be weakly differentiated ecologically and subjected to mutual competitive exclusion. Somewhat surprisingly, given the high degree of 
morphological similarity, $D$. desmosa and $D$. borea are well-differentiated genetically.

The ranges of $D$. borea and $D$. pax approach regional sympatry in northwestern Australia. Delma pax is restricted to the mainland Pilbara region where it occupies a variety of local habitat types being only recently recorded on Potter Island off the Pilbara coast. Delma borea, in contrast, is present on several of the western Pilbara islands. On Barrow Island it is found together with $D$. nasuta and $D$. tincta and on Hermite Island it is recorded with $D$. nasuta (Burbidge et al. 2000).

The disjunct occurrence of $D$. borea in northwestern Australia begs explanation. The flora and fauna of Barrow and Hermite Islands off the Pilbara coast are closely allied with those of the Cape Range Peninsula (Keighery and Gibson 1993; Baynes and Jones 1993; Kendrick 1993), reflecting not only the geological similarity between the two areas (both are anticlinal structures comprised of Miocene limestones) but also that during periods of lowered sea level through the late Pliocene and Pleistocene, both formed rocky plateaux on a sandy, emergent continental shelf. Despite this overall similarity, the Pilbara islands host a number of 'northern monsoonal' faunal elements that are absent from the Cape Range Peninsula. One of these is $D$. borea, perhaps replaced on the peninsula by the morphologically similar $D$. tealei. Others include a murid rodent Pseudomys nanus (Gould, 1858) and a skink Ctenotus angusticeps Storr, 1988. Another 'northern monsoonal' mammal species, the Northern Nailtail Wallaby Onychogalea unguifera (Gould, 1841), is represented in an early Holocene subfossil assemblage from the Montebello islands (Veth 1993). These taxa are typically associated either with grassland communities on coastal plains ( $P$. nanus and $O$. unguifera) or with coastal samphire communities ( $C$. angusticeps), vegetation types that were most likely broadly continuous along the emergent northwestern continental shelf during periods of lower sea level. The present distribution of $D$. borea suggests that it, too, was a member of this now emergent continental shelf community that survives in relictual form only on the Pilbara islands.

Molecular clock estimates suggest a staggered origin of the major species group lineages within Delma during the early to mid-Miocene, around 2028 million years ago (Jennings et al. 2003). The Delma tincta group probably arose during the latter part of this radiation. Divergence of the modern species lineages ( $D$. pax, D. tincta, $D$. borea) probably occurred during the late Miocene (ca. 8-9 million years ago). Other speciation events in Delma typically are of similar or even greater antiquity, if the molecular clock estimates are accepted as valid (Jennings et al. 2003).
Delma tealei shows a similar level of genetic differentiation to the other previously recognized members of the $D$. tincta group and thus may also have originated during the late Miocene. This corresponds closely to the time of emergence of the Cape Range (Wyrwoll et al. 1993) and it is tempting to link the two events via a dispersal or vicariance event. However, the probable great antiquity of the $D$. tealei lineage (as indicated by its genetic distinctiveness) leaves open the possibility that $D$. tealei was formerly more widespread under the very different bioclimatic regime of the late Tertiary period and is relictual on Cape Range Peninsula. Delma desmosa, in contrast, is genetically close to its sibling $D$. pax and these taxa probably diverged during the late Pliocene or Pleistocene (i.e., within the last 2-3 million years). In broad terms, this corresponds to the period of progressive desertification of Australia (White 1994; Fujioka et al. 2005) and it seems likely that this later period of diversification within the $D$. tincta group occurred in response to the emergence of new kinds of arid zone habitats.

\section{Species identification in Delma and a new dichotomous key}

As noted in the Introduction, this study was initiated in response to seemingly anomalous identifications of Pilbara Delma specimens obtained through application of the key published in Storr et al. (1990: 114). In most cases, this confusion involved individuals of $D$. pax or $D$. desmosa in which the third supralabial scale is divided unilaterally or bilaterally, thereby leading to ambiguity at the second key couplet in which the relationship of supralabial scales to the eye is used. Similar difficulties were also encountered as a consequence of intraspecific variation in other 'diagnostic' characters within the genus Delma, including the condition of the supranasal scales, the number of midbody scale rows and aspects of head patterning. Fundamentally, these difficulties reflect the fact that the genus Delma is speciose yet morphologically conservative. Moreover, problems of identification are compounded by marked ontogenetic transformations in head pattern that occur in some species of Delma but not in others.

In conclusion, we offer a revised dichotomous key to the Delma species of Western Australia. Given the difficulties in accurate identification of this group, we suggest that the key be used only as a first step towards taxonomic identification of adult specimens, which should then be confirmed by direct comparison with voucher material or through genetic analysis. Moreover, if possible, we recommend that the following conditions be met prior to application of the key: 1) that the stage of sexual maturity of individual animals is determined; 2) that 'typical' scalation characters are determined 
through examination of locally obtained series rather than individual specimens; and 3) that close attention is paid not only to the small number of standard diagnostic features employed in the key but also to subtleties of head and body scale patterning within regional Delma assemblages.

\section{Key to Western Australian Delma}

1. Typically one pair of supranasals 2

Typically two pairs of supranasals 3

2. Smaller (SVL up to $57 \mathrm{~mm}$ ); typically 18 midbody scale rows; side of neck and forebody usually finely barred with black; no broad dark bands across head and neck

australis

Longer (SVL up to $92 \mathrm{~mm}$ ); typically 14 midbody scale rows; side of forebody usually with variably coloured scales; broad dark bands across head and neck (often fade with age) tincta

3. Typically third supralabial below the eye; typically 14 midbody scale rows; Cape Range Peninsula tealei

Either third or fourth supralabial below the eye; between 16-20 midbody scale rows .... 4

4. Typically third (occasionally fourth) supralabial below the eye.

Typically fourth supralabial below the eye .... 6

5. Dark bands across head and neck persistent at all ages; two dark smudges on infralabials below lores; deserts desmosa

Dark bands across head and neck absent in adults; three dark smudges on infralabials below lores; Pilbara pax

6. Typically 16 midbody scale rows ..................... 7

Typically 18 midbody scale rows. 8

7. Throat white; Kimberley and some Pilbara islands borea

Throat with fine dark variegations; southwest of WA fraseri

8. Dark bands across head and neck descend obliquely forwards, terminating acutely; Pilbara elegans

Dark bands run straight across head and neck and meet to form black bands across the chin and throat; southern Great Victoria Desert ...

petersoni

9. Narrow, wavy pale bands across head and neck haroldi

No pale bands across head and neck 10

10. Side of forebody with numerous pale vertical streaks or bars; lower surface yellow ... grayii
Side of forebody without numerous pale vertical streaks or bars; lower surface white with or without dark markings 11

11. Snout long; dorsal scales spotted and flecked with dark brown; ventral scales usually darkedged nasuta

Snout short; dorsal scales finely dark-edged; ventral scales without dark edges ........ butleri

\section{ACKNOWLEDGEMENTS}

This study would not have been possible without financial support for the genetic examinations from Methanex Australia Pty. Ltd. R. How, P. Doughty and $C$. Stevenson of the Western Australian Museum provided support and assistance during the study. We are grateful to R. O'Shea formerly of the Western Australian Museum for doing the head drawings and taking photographs of preserved specimens. L. Schmitt of the University of Western Australia kindly provided statistical advice. $P$. Horner and G. Dally of the Northern Territory Museum, M. Hutchinson and C. Secombe of the South Australian Museum and R. Sadlier of the Australian Museum kindly allowed access to specimens. G. Shea, M. Hutchinson and P. Doughty offered insightful comments of the manuscript.

Thanks also to the many field herpetologists in Western Australia who have made substantial contributions to the Delma collection of the Western Australian Museum, most notably D. Algaba, B. Bush, R. Browne-Cooper, G. Harold, P. Kendrick, D. Pearson, D. Robinson and R. Teale.

\section{REFERENCES}

Adams, M., Baverstock, P.R. and Reardon, T. (1987). Electrophoretic resolution of species boundaries in Australian Microchiroptera. I. Eptesicus (Chiroptera, Vespertilionidae). Australian Journal of Biological Sciences 40: 143-162.

Aplin, K.P. (1998). Three new blindsnakes (Squamata: Typhlopidae) from northwestern Australia. Records of the Westem Australian Museum 19: 1-12.

Aplin, K.P. and Smith, L.A. (2001). Checklist of the frogs and reptiles of Western Australia. Records of the Westem Australian Museum Supplement No. 63: 5174.

Baynes, A. and Jones, B. (1993). The mammals of Cape Range peninsula, north-western Australia. Pp. 207225 in W.F. Humphreys (ed.) The Biogeography of Cape Range, Western Australia. Records of the Western Australian Museum Supplement No. 45.

Burbidge, A.A., Blyth, J.D., Fuller, P.J., Kendrick, P.G., Stanley, F.J. and Smith, L.A. (2000). The terrestrial vertebrate fauna of the Montebello Islands, Western Australia. CALM Science 3: 95-107.

Cogger, H.G. and Heatwole, H. (1981). The Australian reptiles: Origins, biogeography, distribution patterns 
and island evolution. Pp 1331-1373 in Ecological biogeography of Australia (A. Keast ed.) Dr W. Junk, The Hague.

Cogger, H.G. (2000). Reptiles and Amphibians of Australia. Reed New Holland, Frenchs Forest, NSW.

Ehmann, H. (1992). Encyclopedia of Australian Animals. Reptiles. Angus \& Robertson, Sydney.

Ehmann, H. (2005). South Australian Rangelands and Aboriginal Lands Wildlife Management Manual. Department of Water, Land and Biodiversity Conservation, South Australia.

Felsenstein, J. (1993). PHYLIP (Phylogeny Inference Package. Version 3.5c). Distributed by the author, University of Washington, Seattle.

Fujioka, T., Chappell, J. Honda, M., Yatsevich, I., Fifield, $\mathrm{K}$. and FAbel, D. (2005). Global cooling initiated stony deserts in central Australia 2-4 Ma,dated by cosmogenic 21Ne-10Be. Geology 33: 993-996.

How, R.A. and Cowan, M.A. (2006). Collections in space and time: geographical patterning of native frogs, mammals and reptiles through a continental gradient. Pacific Conservation Biology 12: 111-133.

Ingram, G.J. and Raven, R.J. (1991) eds. An atlas of Queensland's Frogs, Reptiles, Birds and Mammals. Queensland Museum.

Jennings, W.B., Pianka, E.R. and Donnellan, S. (2003). Systematics of the Lizard Family Pygopodidae with Implications for the Diversification of Australian Temperate Biotas. Systematic Biology 52: 757-780.

Keighery, G. and Gibson, N. (1993). Biogeography and composition of the flora of the Cape Range peninsula, Western Australia. Pp. 51-85 in W.F. Humphreys (ed.) The Biogeography of Cape Range, Western Australia. Records of the Western Australian Museum Supplement No. 45.

Kendrick, P.G. (1993). Biogeography of the vertebrates of the Cape Range peninsula, Western Australia. Pp. 193-206 in W.F. Humphreys (ed.) The Biogeography of Cape Range, Western Australia. Records of the Western Australian Museum Supplement No. 45.

Kluge, A.G. (1974). A taxonomic revision of the lizard family Pygopodidae. Miscellaneous Publications of the Museum of Zoology, University of Michigan No. 147: 1-221.

Kluge, A.G. (1976). Phylogenetic relationships in the lizard family Pygopodidae: An evaluation of theory, methods and data. Miscellaneous Publications of the Museum of Zoology, University of Michigan No. 152: $1-72$.

McAlpin, S. (2005). Uluru - Tjuta National Park Vertebrate Fauna Resurvey: 2004. Consultancy Report to Parks Australia North. The author, Lismore.

Page, R.D.M. (1996). TREEVIEW: An application to display phylogenetic trees on personal computers. Computer Applications in the Biosciences 12: 357358.

Reid, J.R.W., Kerle, J.A. and Morton, S.R. (1993). Uluru Fauna. The Distribution and Abundance of Vertebrate Fauna of Uluru (Ayers Rock-Mount Olga) National Park, N.T. Australian National Parks and Wildlife Service series - Kowari, Canberra.
Richardson, B.J., Baverstock, P.R. and Adams, M. (1986). Allozyme Electrophoresis: A Handbook for Animal Systematics and Population Studies. Academic Press, Sydney.

Robinson, A.C., Copley, P.B., Canty, P.D., Baker, L.M. and Nesbitt, B.J. (2003). A biological survey of the Anangu Pittjantjatjara Lands South Australia. South Australian Department for Environment and Heritage, Adelaide.

Shea, G.M. (1987). Two new Species of Delma (Lacertilia: Pygopodidae) from northeastern Queensland and a Note on the Status of the Genus Aclys. Proceedings of the Linnean Society of New South Wales 109: 203212.

Shea, G.M. (1991). Revisionary notes on the genus Delma (Squamata: Pygopodidae) in South Australia and the Northern Territory. Records of the South Australian Museum 25: 71-90.

Smith, L.A. and Adams, M. (2006). Revision of the Lerista muelleri species-group (Lacertilia: Scincidae) in Western Australia, with a redescription of Lerista muelleri (Fischer, 1881) and the description of nine new species. Records of the Western Australian Museum (in press).

Storr, G.M. (1987). Three new legless lizards (Pygopodidae) from Western Australia. Records of the Western Australian Museum 13: 345-355.

Storr, G.M. and Hanlon, T.M.S. (1980). Herpetofauna of the Exmouth Region, Western Australia. Records of the Western Australian Museum 8: 423-439.

Storr, G.M., Smith, L.A. and Johnstone, R.E. (1990). Lizards of Western Australia. III Geckos \& Pygopods. Western Australian Museum.

Storr, G.M., Smith, L.A. and Johnstone, R.E. (2002). Snakes of Western Australia. Revised Edition. Western Australian Museum.

Veth, P. (1993). The Aboriginal occupation of the Montebello Islands, north-west Australia. Australian Aboriginal Studies 24: 81-89.

White, M.E. (1994). After the greening, the browning of Australia. Kangaroo Press, Kenthurst, Australia.

Wilson, S.K. and Knowles, D.G. (1988). Australia's Reptiles. A photographic reference to the Terrestrial Reptiles of Australia. Collins, Sydney.

Wilson, S.K. and Swan G. (2003). A Complete Guide to Reptiles of Australia. Reed New Holland, Frenchs Forest, NSW.

Wyrwoll, K.-H., Kendrick, G.W. and Long, J.A. (1993). The geomorphology and Late Cenozoic geomorphological evolution of the Cape Range Exmouth Gulf region. In W.F. Humphreys (ed.) The Biogeography of Cape Range, Western Australia. Records of the Western Australian Museum Supplement No. 45: 1-23.

Manuscript received 9 November 2005; accepted 10 November 2006 
Lists of Specimens examined

\section{APPENDIX 1}

Legend for Museum registration numbers: WAM = Western Australian Museum; NTM = Northern Territory Museum; SAM = South Australian Museum.

Delma borea Kluge 1974

SAM: 42018-20, 42046, $421892 \mathrm{~km}$ W Hanging Knoll (26¹9'23"S 130²3'36"E).

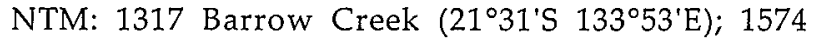
Tanami Bore $\left(19^{\circ} 58^{\prime} \mathrm{S} 12^{\circ} 40^{\prime} \mathrm{E}\right) ; 5371$ Barrow Creek

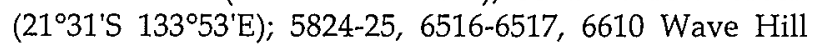
$\left(17^{\circ} 29^{\prime} \mathrm{S} 130^{\circ} 57^{\prime} \mathrm{E}\right) ; 659470 \mathrm{~km}$ N Top Springs $\left(16^{\circ} 00^{\prime} \mathrm{S}\right.$

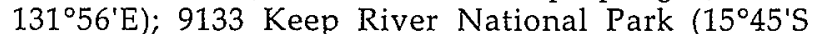

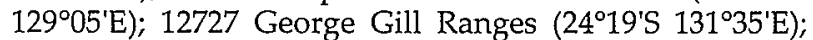
13047 Ord River (16 $\left.10^{\circ} \mathrm{S} 128^{\circ} 44^{\prime} \mathrm{E}\right) ; 15414$ Chewings Range ( $\left.23^{\circ} 40^{\prime} \mathrm{S} 132^{\circ} 54^{\prime} \mathrm{E}\right) ; 16473$ Sambo Bore, Wave Hill Station (18 $\left.{ }^{\circ} 53^{\prime} \mathrm{S} 130^{\circ} 40^{\prime} \mathrm{E}\right)$; 18042 Alyawarre Desert Area $\left(20^{\circ} 44^{\prime} \mathrm{S} 135^{\circ} 50^{\prime} \mathrm{E}\right) ; 20644$ Finke Gorge National Park (240.'30"S 132०40'39"E); 20660 Finke Gorge National

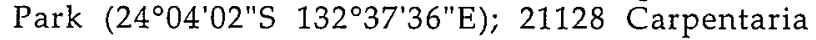
Highway $\left(16^{\circ} 44^{\prime} \mathrm{S} 135^{\circ} 02^{\prime} \mathrm{E}\right) ; 22702$ Macdonnell Ranges

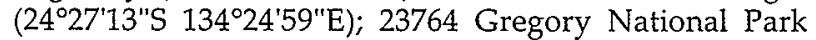
(16²9'43"S 130¹1'01"E); 23765 Gregory National Park

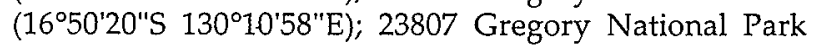
(16 $\left.47^{\circ} 50^{\prime \prime S} 130^{\circ} 09^{\prime} 15^{\prime \prime} \mathrm{E}\right) ; 25495$ Jasper Gorge (16 $05^{\circ} 50^{\prime \prime} \mathrm{S}$ $\left.130^{\circ} 45^{\prime} 18^{\prime \prime} \mathrm{E}\right)$; 34524-25 Arltunga Ruins (23⒉ $6^{\prime} \mathrm{S} 134^{\circ} 42^{\prime} \mathrm{E}$ ). WAM: 13496 Yirrkala $\left(12^{\circ} 15^{\prime} \mathrm{S} 136^{\circ} 53^{\prime} \mathrm{E}\right) ; 218528 \mathrm{~km} \mathrm{~N}$ Kalumburu (14\% $\left.14^{\prime} \mathrm{S} 126^{\circ} 37^{\prime} \mathrm{E}\right) ; 21980$ Darwin (12 $27^{\prime} \mathrm{S}$ $\left.130^{\circ} 50^{\prime} \mathrm{E}\right) ; 23480$ Nightcliff $\left(12^{\circ} 23^{\prime} \mathrm{S} 130^{\circ} 52^{\prime} \mathrm{E}\right) ; 2400111$ $\mathrm{km} N$ Adelaide River $\left(13^{\circ} 08^{\prime} \mathrm{S} 131^{\circ} 08^{\prime} \mathrm{E}\right) ; 24198$ Helen Springs $\left(18^{\circ} 26^{\prime} S 133^{\circ} 52^{\prime} \mathrm{E}\right) ; 26224$ Parap $\left(12^{\circ} 25^{\prime} \mathrm{S}\right.$ $\left.130^{\circ} 52^{\prime} \mathrm{E}\right) ; 28656$ Barrow Island (20 $\left.20^{\circ} \mathrm{S} 115^{\circ} 25^{\prime} \mathrm{E}\right) ; 34331-$ 32 Yirrkala (12 $\left.{ }^{\circ} 15^{\prime} \mathrm{S} 136^{\circ} 53^{\prime} \mathrm{E}\right) ; 37371$ Rosemary Island $\left(20^{\circ} 29^{\prime} \mathrm{S} 116^{\circ} 35^{\prime} \mathrm{E}\right)$; 37406 Hermite Island $\left(20^{\circ} 29^{\prime} \mathrm{S}\right.$ $\left.115^{\circ} 31^{\prime} \mathrm{E}\right) ; 40296,40835$ Darwin (12²7'S 130 $\left.50^{\circ} \mathrm{E}\right) ; 41271$ Augustus Island (15'19'S $\left.124^{\circ} 32^{\prime} \mathrm{E}\right) ; 41370$ Heywood Island $\left(15^{\circ} 20^{\prime} \mathrm{S} 124^{\circ} 20^{\prime} \mathrm{E}\right) ; 41409$ Coronation Island (1500'S $\left.124^{\circ} 56^{\prime} \mathrm{E}\right) ; 43071-75$ Crystal Creek $\left(14^{\circ} 31^{\prime} \mathrm{S}\right.$ $\left.125^{\circ} 48^{\prime} \mathrm{E}\right) ; 43119$ Port Warrender (14 $\left.{ }^{\circ} 34^{\prime} \mathrm{S} 125^{\circ} 51^{\prime} \mathrm{E}\right)$; 43151, 43185, 43204, 43211, 43341-42 Mitchell Plateau (14 $\left.{ }^{\circ} 52^{\prime} \mathrm{S} 125^{\circ} 50^{\prime} \mathrm{E}\right) ; 44278$ Geikie Gorge $\left(1^{\circ} 05^{\prime} \mathrm{S} 125^{\circ} 43^{\prime} \mathrm{E}\right)$; 44566-71 Behn River Mouth, Lake Argyle (16 $15^{\prime} \mathrm{S}$ $\left.128^{\circ} 45^{\prime} \mathrm{E}\right) ; 44572-75$ Ord River (16 $\left.{ }^{\circ} 17^{\prime} \mathrm{S} 128^{\circ} 47^{\prime} \mathrm{E}\right) ; 45066$

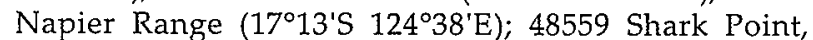
Barrow Island (20 52 'S 115 25'E); 51277 East Palm Spring, Denison Range (19'20'S $\left.128^{\circ} 20^{\prime} \mathrm{E}\right)$; 52670 Lake Argyle

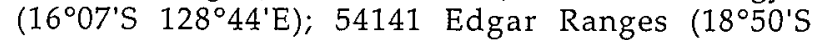
$\left.123^{\circ} 15^{\prime} \mathrm{E}\right) ; 56208-09$ Crystal Creek (14.30'S $\left.125^{\circ} 47^{\prime} \mathrm{E}\right)$; 57039 Doongan Homestead $\left(15^{\circ} 23^{\prime} \mathrm{S} 126^{\circ} 18^{\prime} \mathrm{E}\right) ; 603523$ $\mathrm{km}$ E Nicholson $\left(18^{\circ} 03^{\prime} \mathrm{S} 128^{\circ} 55^{\prime} \mathrm{E}\right) ; 69845$ Koolan Island (16 $\left.09^{\circ} \mathrm{S} 123^{\circ} 45^{\prime} \mathrm{E}\right) ; 7036512.5 \mathrm{~km} 309^{\circ} \mathrm{New}$ Lissadell Homestead (16 $\left.36^{\circ} 12^{\prime \prime S} 128^{\circ} 27^{\prime} 34^{\prime \prime E}\right) ; 7038510.5 \mathrm{~km}$ $249^{\circ} \mathrm{New}$ Lissadell Homestead (16 $\left.{ }^{\circ} 43^{\prime} \mathrm{S} 128^{\circ} 27^{\prime} \mathrm{E}\right) ; 70564$

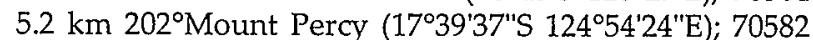

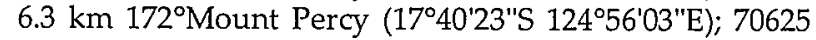

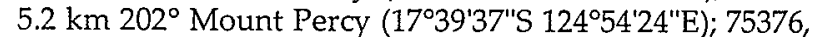
$7539812 \mathrm{~km}$ NW New Lissadell Homestead (16³7'S $\left.128^{\circ} 28^{\prime} \mathrm{E}\right) ; 7553311 \mathrm{~km}$ WNW New Lissadell Homestead

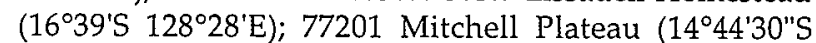
$\left.125^{\circ} 47^{\prime} 00^{\prime \prime E}\right) ; \quad 77472$ Camp Creek (14\%53'30"S $\left.125^{\circ} 45^{\prime} 00^{\prime \prime E}\right) ; 79063$ Brooking Springs Station (17 $54^{\circ} \mathrm{S}$ $\left.125^{\circ} 16^{\prime} \mathrm{E}\right) ; 80028$ Sunday Island $\left(16^{\circ} 25^{\prime} \mathrm{S} 123^{\circ} 11^{\prime} \mathrm{E}\right) ; 81286$ Koolan Island (16 $\left.09^{\prime} \mathrm{S} 123^{\circ} 45^{\prime} \mathrm{E}\right) ; 94881$ Lake Argyle ( $\left.16^{\circ} 07^{\prime} \mathrm{S} 128^{\circ} 42^{\prime} \mathrm{E}\right)$; 96784 Sale River (16 $\left.06^{\circ} \mathrm{S} 124^{\circ} 40^{\prime} \mathrm{E}\right)$; 96828 Camden Head (15 $\left.30^{\prime} \mathrm{S} 124^{\circ} 37^{\circ} \mathrm{E}\right)$; 96944 The Dromedaries (16⒊'20"S 124'56'40"E); $970913.7 \mathrm{~km} \mathrm{NW}$

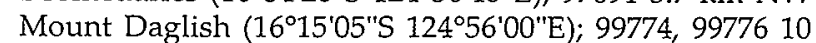

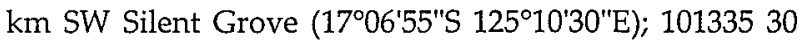
$\mathrm{km}$ ENE Calwynyardah Homestead (17\%57'S $\left.125^{\circ} 02^{\prime} \mathrm{E}\right)$; 103120, 103129 Purnululu National Park $\left(17^{\circ} 26^{\prime}\right.$ 'S $\left.128^{\circ} 24^{\prime} E\right) ; 103151$ Purnululu National Park $\left(17^{\circ} 33^{\prime} S\right.$ $\left.128^{\circ} 15^{\prime} \mathrm{E}\right) ; 103207$ Purnululu National Park $\left(17^{\circ} 10^{\prime} \mathrm{S}\right.$ $128^{\circ} 44^{\prime}$ E); 103384, 103395 Purnululu National Park (17 $15^{\prime}$ S $\left.128^{\circ} 18^{\prime} E\right) ; 103483$ Purnululu National Park (17'32'S $\left.128^{\circ} 21^{\prime} \mathrm{E}\right) ; 103489-90$ Purnululu National Park $\left(17^{\circ} 29^{\prime} \mathrm{S} 128^{\circ} 22^{\prime} \mathrm{E}\right) ; 103733 \mathrm{Koolan}$ Island $\left(16^{\circ} 09^{\prime} \mathrm{S}\right.$ $\left.123^{\circ} 45^{\prime} \mathrm{E}\right) ; 106284$ Augustus Island $\left(15^{\circ} 26^{\prime} \mathrm{S} 124^{\circ} 36^{\prime} \mathrm{E}\right)$; $10873710 \mathrm{~km} \mathrm{~N}$ Gordon Downs Homestead (18 $40^{\circ} \mathrm{S}$ $\left.128^{\circ} 35^{\prime} \mathrm{E}\right) ; 10881530 \mathrm{~km}$ SE Gordon Downs Homestead (18 $\left.{ }^{\circ} 56^{\prime} \mathrm{S} 128^{\circ} 47^{\prime} \mathrm{E}\right)$; $112725-26$ Mandora Station (19² $47^{\prime} 52^{\prime \prime} \mathrm{S}$ $\left.121^{\circ} 26^{\prime} 53^{\prime \prime E}\right) ; 114462 \mathrm{King}$ Hall Island $\left(16^{\circ} 05^{\prime} \mathrm{S} 123^{\circ} 25^{\prime} \mathrm{E}\right)$; 138149 Napier Range (17 $\left.13^{\circ} \mathrm{S} 124^{\circ} 38^{\prime} \mathrm{E}\right) ; 139058,139062-$

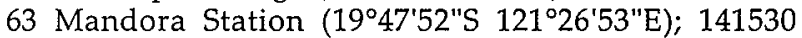
Quanbun Downs Station (18 $\left.21^{\prime} 27^{\prime \prime} S 125^{\circ} 13^{\prime} 10^{\prime \prime} \mathrm{E}\right)$.

\section{Delma pax Kluge 1974}

NTM: $993924 \mathrm{~km}$ N Port Hedland $\left(20^{\circ} 23^{\prime} \mathrm{S} 118^{\circ} 48^{\prime} \mathrm{E}\right)$; $994313 \mathrm{~km} N$ Port Hedland $\left(20^{\circ} 25^{\prime} \mathrm{S} 118^{\circ} 42^{\prime} \mathrm{E}\right) ; 994515$ $\mathrm{km}$ N Port Hedland $\left(20^{\circ} 25^{\prime} \mathrm{S} 118^{\circ} 42^{\prime \prime} \mathrm{E}\right) ; 994622 \mathrm{~km} \mathrm{~N}$ Port Hedland $\left(20^{\circ} 23^{\prime} \mathrm{S} 118^{\circ} 47^{\prime} \mathrm{E}\right)$.

WAM: $1480319 \mathrm{~km} \mathrm{~W}$ Mundabullangana (20³0'S $\left.117^{\circ} 53^{\prime} \mathrm{E}\right) ; 5162010 \mathrm{~km}$ NE Mount Newman (23ำ $17^{\prime} \mathrm{S}$ $\left.119^{\circ} 45^{\prime} \mathrm{E}\right) ; 58965$ Marble Bar Pool (21ำ $\left.16^{\prime} \mathrm{S} 119^{\circ} 42^{\prime} \mathrm{E}\right)$; 64701 Nullagine $\left(21^{\circ} 54^{\prime} \mathrm{S} 120^{\circ} 06^{\prime} \mathrm{E}\right)$; 64986 Dampier (20 $\left.40^{\prime} \mathrm{S} 116^{\circ} 42^{\prime} \mathrm{E}\right)$; 68370-71 Between Nullagine and Roy Hill $\left(22^{\circ} 15^{\prime} \mathrm{S} 120^{\circ} 00^{\prime} \mathrm{E}\right) ; 70103$ Between Dampier and Karratha $\left(20^{\circ} 45^{\prime} \mathrm{S} 116^{\circ} 45^{\prime} \mathrm{E}\right) ; 73144,7314624.2 \mathrm{~km}$

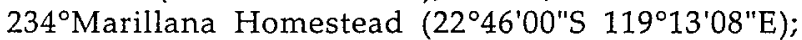
73542-43 Dampier (20⒋ $\left.40^{\prime} \mathrm{S} 116^{\circ} 42^{\prime} \mathrm{E}\right) ; 7360424.2 \mathrm{~km}$ $234^{\circ}$ Marillana Homestead ( $\left.22^{\circ} 46^{\prime} 00^{\prime \prime S} 119^{\circ} 13^{\prime} 08^{\prime \prime} \mathrm{E}\right)$; 73841

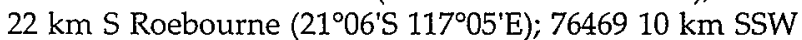
Cooya Pooya Homestead $\left(21^{\circ} 07^{\prime} \mathrm{S} 117^{\circ} 07^{\prime} \mathrm{E}\right) ; 80379$ Carrawella Well $\left(21^{\circ} 43^{\prime} \mathrm{S} 115^{\circ} 31^{\prime} \mathrm{E}\right) ; 805998 \mathrm{~km} \mathrm{SE}$ Peedamulla Homestead (21 $\left.{ }^{\circ} 55^{\prime} \mathrm{S} 115^{\circ} 40^{\prime} \mathrm{E}\right)$; 80995-96 South Hedland $\left(20^{\circ} 24^{\prime} \mathrm{S} 118^{\circ} 36^{\prime} \mathrm{E}\right)$; $81387-91$ Miaree Pool $\left(20^{\circ} 51^{\prime} \mathrm{S} 116^{\circ} 37^{\prime} \mathrm{E}\right) ; 82605$ Carawine Gorge (21⒉ $29^{\prime} \mathrm{S}$ $\left.121^{\circ} 01^{\prime} \mathrm{E}\right) ; 83153$ Karratha $\left(20^{\circ} 44^{\prime} \mathrm{S} 116^{\circ} 51^{\prime} \mathrm{E}\right) ; 84982$ Dampier Archipelago (20 $\left.33^{\circ} \mathrm{S} 116^{\circ} 42^{\prime} \mathrm{E}\right)$; 87854 Wickham

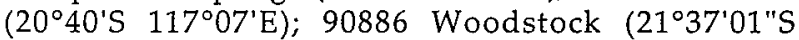

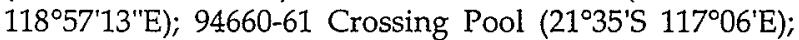
94882 Mardie Station (21 $\left.{ }^{\circ} 15^{\prime} \mathrm{S} 115^{\circ} 50^{\prime} \mathrm{E}\right) ; 1020462 \mathrm{~km} \mathrm{~N}$ Crossing Pool $\left(20^{\circ} 53^{\prime} \mathrm{S} 116^{\circ} 40^{\prime} \mathrm{E}\right) ; 102066$ Karratha

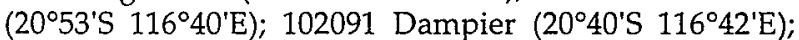

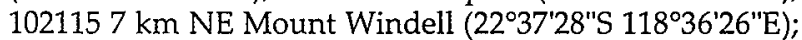

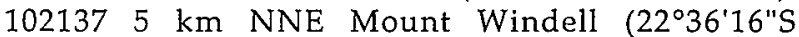
$118^{\circ} 34^{\prime} 01^{\prime \prime E) ; ~} 10214910 \mathrm{~km}$ ENE Mount Windell

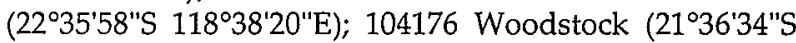
$\left.119^{\circ} 01^{\prime} 17^{\prime \prime E}\right) ; 104297$ Woodstock (21⒊ $36^{\prime 2} 25^{\prime \prime S} 119^{\circ} 02^{\prime 2} 23^{\prime \prime E}$ ); 106257, 106278-79, 108711, 108791, 113387 South Hedland $\left(20^{\circ} 24^{\prime} \mathrm{S} 118^{\circ} 36^{\prime} \mathrm{E}\right) ; 114437$ Wittenoom $\left(22^{\circ} 14^{\prime} \mathrm{S} 118^{\circ} 20^{\prime} \mathrm{E}\right)$; 116300 King Bay $\left(20^{\circ} 38^{\prime} \mathrm{S} 116^{\circ} 45^{\prime} \mathrm{E}\right) ; 119045-46$ South Hedland $\left(20^{\circ} 24^{\prime} \mathrm{S} 118^{\circ} 36^{\prime} \mathrm{E}\right) ; 1200213.5 \mathrm{~km}$ NE Mount Brockman $\left(22^{\circ} 28^{\prime} \mathrm{S} 117^{\circ} 18^{\prime} \mathrm{E}\right) ; 120030$ Hope Downs

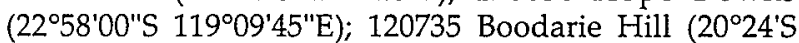
$\left.118^{\circ} 31^{\prime} \mathrm{E}\right) ; 125023$ Yandicoogina $\left(22^{\circ} 43^{\prime} \mathrm{S} 119^{\circ} 01^{\prime} \mathrm{E}\right)$; $12545230 \mathrm{~km}$ E Newman (23 $\left.{ }^{\circ} 19^{\prime} \mathrm{S} 120^{\circ} 02^{\prime} \mathrm{E}\right) ; 127829$

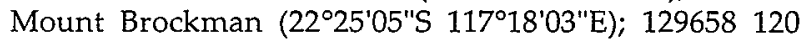
km NW Newman (22 $\left.59^{\prime} 45^{\prime \prime S} 119^{\circ} 18^{\prime} 30^{\prime \prime E}\right) ; 129930$ West Angelas $\left(23^{\circ} 15^{\prime} \mathrm{S} 118^{\circ} 40^{\prime} \mathrm{E}\right)$; 132548 DeGrey River Station 
(2013'14"S 119०09'58"E); 132549 DeGrey River Station (2017'16"S 119¹2'36"E); 132593, 132596 Burrup Peninsula $\left(20^{\circ} 36^{\prime} 45^{\prime \prime S} 116^{\circ} 47^{\prime} 37^{\prime \prime E}\right) ; 132606$ Burrup Peninsula (2040'49"S $\left.116^{\circ} 44^{\prime} 37^{\prime \prime E}\right) ; 132657$ Burrup Peninsula (2031'40"S 116 $\left.49^{\prime} 11^{\prime \prime E}\right) ; 135320$, 135336-37 Cape Lambert (2048'36"S 116 $\left.56^{\circ} 31^{\prime \prime E}\right) ; 135632$ Bea Bea Creek (21 $\left.{ }^{\circ} 43^{\prime} \mathrm{S} 118^{\circ} 44^{\prime} \mathrm{E}\right)$; $135919-2032 \mathrm{~km}$ SW South Hedland $\left(20^{\circ} 36^{\prime} S 118^{\circ} 22^{\prime} \mathrm{E}\right) ; 137857$ Munjina Roadhouse (21 $\left.1^{\circ} 59^{\prime} \mathrm{S} 119^{\circ} 45^{\prime} \mathrm{E}\right)$; $139170-71$ Cane River Homestead

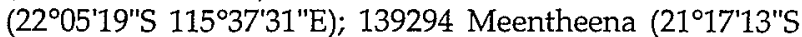
$\left.120^{\circ} 27^{\prime} 34^{\prime \prime} \mathrm{E}\right)$; $139352-53$ Potter Island $\left(20^{\circ} 57^{\prime} \mathrm{S} 116^{\circ} 08^{\prime} \mathrm{E}\right)$; 139369 Meentheena (21ำ $\left.13^{\prime} 56^{\prime \prime S} 120^{\circ} 19^{\prime} 40^{\prime \prime} \mathrm{E}\right) ; 139457$

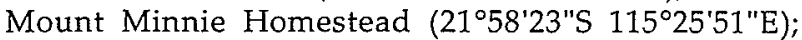
140021 Millstream-Chichester National Park (21 ${ }^{\circ} 10^{\prime} 53^{\prime \prime}$ 'S $\left.117^{\circ} 03^{\prime} 28^{\prime \prime} \mathrm{E}\right) ; 14039682 \mathrm{~km}$ E Port Hedland (20¹8'53"S $\left.119^{\circ} 24^{\prime} 41^{\prime \prime E}\right) ; 141269-7024 \mathrm{~km}$ ESE Port Hedland (20²3'S $\left.118^{\circ} 48^{\prime} \mathrm{E}\right) ; 141311$ Cape Preston area $\left(20^{\circ} 50^{\prime} 00^{\prime \prime S}\right.$

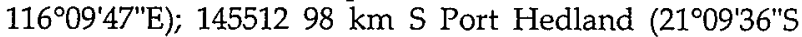
$\left.118^{\circ} 48^{\prime} 36^{\prime \prime E}\right) ; 14554480 \mathrm{~km}$ S Port Hedland $\left(21^{\circ} 00^{\prime} 36^{\prime \prime S}\right.$ $\left.118^{\circ} 42^{\prime} 00^{\prime \prime E}\right) ; 14556934 \mathrm{~km}$ S Port Hedland (20³6'36"S $\left.118^{\circ} 36^{\prime} 36^{\prime \prime E}\right) ; 14561418 \mathrm{~km} S$ Port Hedland $\left(20^{\circ} 28^{\prime} 12^{\prime \prime} \mathrm{S}\right.$ $\left.118^{\circ} 35^{\prime} 24^{\prime \prime E}\right) ; 145680$ Abydos Station (21⒉ $\left.15^{\prime} \mathrm{S} 118^{\circ} 55^{\prime} \mathrm{E}\right)$; 145748 Chichester Range ( $\left.22^{\circ} 04^{\prime} 44^{\prime \prime} \mathrm{S} 118^{\circ} 58^{\prime} 40^{\prime \prime} \mathrm{E}\right)$; 145753 Chichester Range (22.01'01"S 118 58'55"E); 146591124

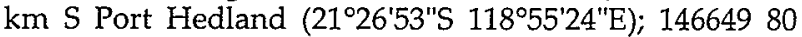

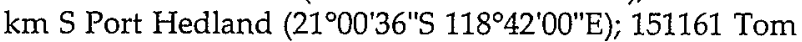

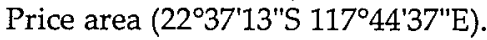

\section{Delma tincta De Vis 1888}

WAM: $3440 \mathrm{La}$ Grange (18 $\left.40^{\prime} \mathrm{S} 122^{\circ} 01^{\prime} \mathrm{E}\right) ; 4511$ East Chapman $\left(28^{\circ} 40^{\prime} \mathrm{S} 114^{\circ} 50^{\prime} \mathrm{E}\right) ; 8109$ Wandagee Station $\left(23^{\circ} 49^{\prime} \mathrm{S} 114^{\circ} 27^{\prime} \mathrm{E}\right)$; $9782-84$ Carnarvon $\left(24^{\circ} 53^{\prime} \mathrm{S} 113^{\circ} 40^{\prime} \mathrm{E}\right)$; 10615 Minilya $\left(23^{\circ} 51^{\prime} \mathrm{S} 113^{\circ} 58^{\prime} \mathrm{E}\right)$; 11494 Learmonth district $\left(22^{\circ} 15^{\prime} \mathrm{S} 114^{\circ} 05^{\prime} \mathrm{E}\right) ; 12114$ Kimberley Research

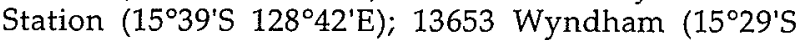
$\left.128^{\circ} 07^{\prime} \mathrm{E}\right) ; 13838 \mathrm{Kalumburu}\left(14^{\circ} 18^{\prime} \mathrm{S} 126^{\circ} 38^{\prime} \mathrm{E}\right) ; 13933$ Mount Pleasant * $\left(32^{\circ} 02^{\prime} \mathrm{S} \quad 115^{\circ} 51^{\prime} \mathrm{E}\right)$; 14791-95 Northampton $\quad\left(28^{\circ} 21^{\prime} \mathrm{S} \quad 114^{\circ} 38^{\prime} \mathrm{E}\right) ; \quad 14801$ Mundabullangana ( $\left.20^{\circ} 31^{\prime} \mathrm{S} 118^{\circ} 03^{\prime} \mathrm{E}\right) ; 17683$ Turee Creek Station (23⒊ $\left.37^{\prime} S 118^{\circ} 39^{\prime} \mathrm{E}\right) ; 22323$ Nabawa $\left(28^{\circ} 30^{\prime} \mathrm{S}\right.$ $\left.114^{\circ} 47^{\prime} \mathrm{E}\right) ; 22366$ Kimberley Research Station (15 $35^{\circ} \mathrm{S}$ $\left.128^{\circ} 42^{\prime} \mathrm{E}\right) ; 24812$ Binnu $\left(28^{\circ} 02^{\prime} \mathrm{S} 114^{\circ} 40^{\prime} \mathrm{E}\right) ; 25221$ Murchison House $\left(27^{\circ} 39^{\prime} \mathrm{S} \quad 114^{\circ} 14^{\prime} \mathrm{E}\right) ; 28370$ Coordewandy $\left(25^{\circ} 36^{\prime} S 115^{\circ} 58^{\prime} E\right) ; 28391$ Murchison House $\left(27^{\circ} 39^{\prime} \mathrm{S} 114^{\circ} 14^{\prime} \mathrm{E}\right) ; 28454$ Barrow Island $\left(20^{\circ} 48^{\prime} \mathrm{S}\right.$ $\left.115^{\circ} 24^{\prime} \mathrm{E}\right) ; 30259$ Carnarvon $\left(24^{\circ} 53^{\prime} \mathrm{S} 113^{\circ} 40^{\prime} \mathrm{E}\right) ; 3139735$ $\mathrm{km}$ NE Mingenew $\left(29^{\circ} 03^{\prime} \mathrm{S} 115^{\circ} 37^{\prime} \mathrm{E}\right) ; 31487$ Eradu

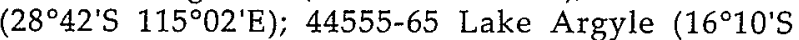

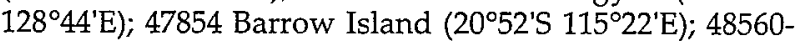
62 Barrow Island $\left(20^{\circ} 52^{\prime} \mathrm{S} 115^{\circ} 25^{\prime} \mathrm{E}\right) ; 50091$ Yalgoo

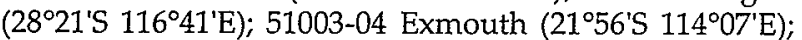

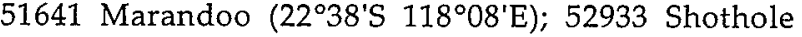
Canyon $\left(22^{\circ} 03^{\prime} \mathrm{S} 114^{\circ} 02^{\prime} \mathrm{E}\right)$; 53791-93 Gascoyne Junction area $\left(25^{\circ} 06^{\prime} \mathrm{S} 115^{\circ} 13^{\prime} \mathrm{E}\right) ; 54606$ Wooramel Homestead

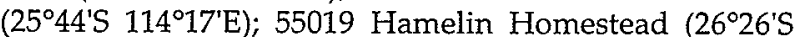
$\left.114^{\circ} 12^{\prime} \mathrm{E}\right) ; 55094$ Wooramel Homestead $\left(25^{\circ} 44^{\prime} \mathrm{S}\right.$ $\left.114^{\circ} 17^{\prime} \mathrm{E}\right) ; 55406-07,5544071 \mathrm{~km}$ W Barry Caves (19²5'S $136^{\circ} 03^{\prime} \mathrm{E}$ ); $584135 \mathrm{~km} \mathrm{~N}$ Coulomb Point (17 ${ }^{\circ} 19^{\prime} \mathrm{S}$ $\left.122^{\circ} 10^{\prime} \mathrm{E}\right) ; 59687,59689$ Meeberrie Homestead $\left(26^{\circ} 58^{\prime} \mathrm{S}\right.$

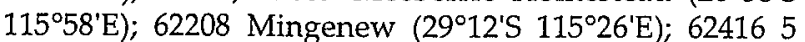
$\mathrm{km} \mathrm{W}$ Williambury Homestead (23⒌' $\left.115^{\circ} 10^{\prime} \mathrm{E}\right) ; 63678$

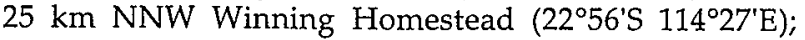

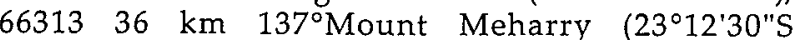
$\left.118^{\circ} 49^{\prime} 30^{\prime \prime E}\right) ; 6631434 \mathrm{~km} 136^{\circ}$ Mount Meharry

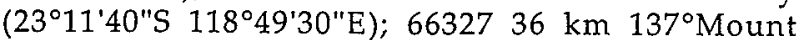

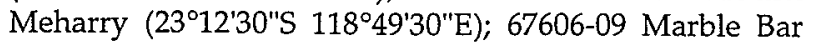
(21 $\left.10^{\circ} \mathrm{S} 119^{\circ} 44^{\prime} \mathrm{E}\right) ; 67806$ Hamelin Pool (26 24'S $\left.114^{\circ} 10^{\prime} \mathrm{E}\right)$;

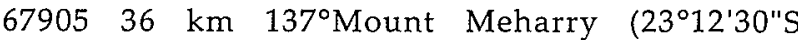

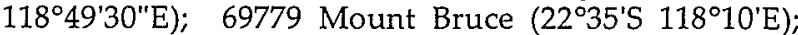

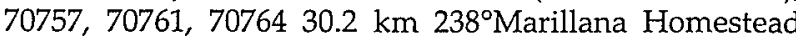
(22 $\left.46^{\prime} 55^{\prime \prime S} 119^{\circ} 09^{\prime} 35^{\prime \prime} \mathrm{E}\right) ; 71059$ Hamelin Homestead $\left(26^{\circ} 26^{\prime} \mathrm{S} 114^{\circ} 12^{\prime} \mathrm{E}\right) ; 7313830.2 \mathrm{~km} 238^{\circ}$ Marillana Homestead $\left(22^{\circ} 46^{\prime} 58^{\prime \prime S} 119^{\circ} 09^{\prime} 35^{\prime \prime} \mathrm{E}\right) ; 73897$ Pender Bay area $\left(16^{\circ} 45^{\prime} \mathrm{S} 122^{\circ} 49^{\prime} \mathrm{E}\right) ; 7823970 \mathrm{~km}$ W Barry Caves $\left(19^{\circ} 51^{\prime} \mathrm{S} 136^{\circ} 02^{\prime} \mathrm{E}\right) ; 8133057 \mathrm{~km}$ NNE Nanutarra Roadhouse $\left(22^{\circ} 01^{\prime} \mathrm{S} 115^{\circ} 36^{\prime} \mathrm{E}\right)$; 83152 Karratha $\left(20^{\circ} 44^{\prime} \mathrm{S}\right.$ $\left.116^{\circ} 51^{\prime} \mathrm{E}\right) ; 83210$ Carnarvon (24.53'S $\left.113^{\circ} 40^{\prime} \mathrm{E}\right)$; $84150-52$ Yalgoo (28 $\left.21^{\circ} \mathrm{S} 116^{\circ} 41^{\prime} \mathrm{E}\right) ; 851908 \mathrm{~km}$ ESE Kununurra $\left(15^{\circ} 49^{\prime} \mathrm{S} 128^{\circ} 48^{\prime} \mathrm{E}\right) ; 86429$ Hamelin Homestead $\left(26^{\circ} 26^{\prime} \mathrm{S}\right.$ $\left.114^{\circ} 12^{\prime} \mathrm{E}\right) ; 88547$ Carnarvon (24. $\left.53^{\circ} \mathrm{S} 113^{\circ} 40^{\prime} \mathrm{E}\right) ; 9113210$ $\mathrm{km}$ NE Paynes Find (29 $\left.11^{\circ} \mathrm{S} 117^{\circ} 42^{\prime} \mathrm{E}\right) ; 92727$ Hamelin Homestead (26 $\left.26^{\circ} \mathrm{S} 114^{\circ} 12^{\prime} \mathrm{E}\right) ; 9370153 \mathrm{~km}$ NNE

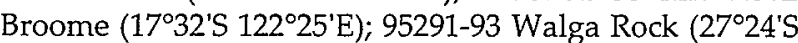
$\left.117^{\circ} 28^{\prime} \mathrm{E}\right) ; 99180$ Woodstock Station (21 $36^{\circ} 35^{\prime \prime} \mathrm{S}$

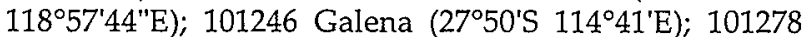
Barrow Island $\left(20^{\circ} 48^{\prime} \mathrm{S} 115^{\circ} 24^{\prime} \mathrm{E}\right) ; 10215410 \mathrm{~km}$ ENE Mount Windell (22 $\left.35^{\circ} 58^{\prime \prime S} 118^{\circ} 38^{\prime} 20^{\prime \prime} \mathrm{E}\right)$; 102401 Barlee Range Nature Reserve $\left(23^{\circ} 04^{\prime} 47^{\prime \prime} \mathrm{S} 115^{\circ} 47^{\prime} 14^{\prime \prime} \mathrm{E}\right)$; 102815

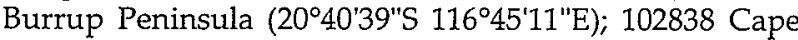

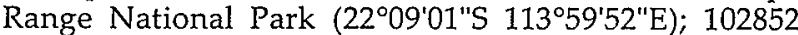

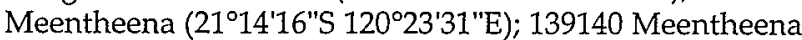
(21⒉ $\left.5^{\prime} 18^{\prime \prime S} 120^{\circ} 25^{\prime} 36^{\prime \prime E}\right) ; 104426,105987$ Carnarvon $\left(24^{\circ} 53^{\prime} \mathrm{S} 113^{\circ} 40^{\prime} \mathrm{E}\right)$; 112511 Urala Station $\left(21^{\circ} 47^{\prime} 04^{\prime \prime} \mathrm{S}\right.$

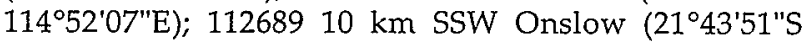
$\left.115^{\circ} 05^{\prime} 49^{\prime \prime} \mathrm{E}\right) ; 1126905.5 \mathrm{~km}$ SE Onslow $\left(21^{\circ} 40^{\prime} 33^{\prime \prime} \mathrm{S}\right.$ $\left.115^{\circ} 08^{\prime} 42^{\prime \prime} \mathrm{E}\right) ; 11269111 \mathrm{~km}$ S Onslow $\left(21^{\circ} 44^{\prime} 27^{\prime \prime} \mathrm{S}\right.$ $\left.115^{\circ} 06^{\prime} 46^{\prime \prime} \mathrm{E}\right) ; 1127155.5 \mathrm{~km}$ SE Onslow $\left(21^{\circ} 40^{\prime} 33^{\prime \prime} \mathrm{S}\right.$

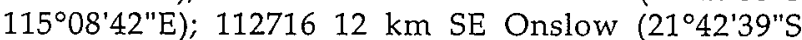

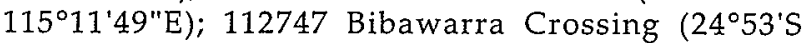
$\left.113^{\circ} 42^{\prime} \mathrm{E}\right)$; 113012,113030 Lesley Salt Works (20 $144^{\prime} 50^{\prime \prime} \mathrm{S}$ $\left.118^{\circ} 50^{\prime} 50^{\prime \prime E}\right)$; 114101-02 Carnarvon Airport (24⒌'S

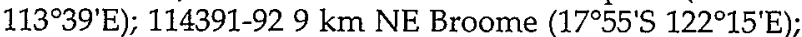
114490 Wicherina Dam (28 $\left.44^{\circ} \mathrm{S} 115^{\circ} 00^{\prime} \mathrm{E}\right) ; 115018$ Spalding Park (28 $\left.39^{\circ} \mathrm{S} 114^{\circ} 38^{\prime} \mathrm{E}\right) ; 11643915 \mathrm{~km}$ NNW Carlton Hill Homestead (15²3'39"S 128 28'13"E); 116545 Depot Hill $\left(29^{\circ} 08^{\prime} \mathrm{S} 115^{\circ} 21^{\prime} \mathrm{E}\right)$; 117215 Narngulu $\left(28^{\circ} 49^{\prime} \mathrm{S}\right.$ $\left.114^{\circ} 41^{\prime} \mathrm{E}\right) ; 117342$ Hope Downs (22 $\left.^{\circ} 56^{\prime} 45^{\prime \prime S} 119^{\circ} 07^{\prime} 30^{\prime \prime} \mathrm{E}\right)$; $1200203.5 \mathrm{~km}$ NE Mount Brockman (22 $\left.28^{\prime} \mathrm{S} 117^{\circ} 18^{\prime} \mathrm{E}\right)$; 125032 Yandicoogina $\left(22^{\circ} 43^{\prime} 14^{\prime \prime S} 118^{\circ} 59^{\prime} 26^{\prime \prime E}\right)$; 127718,

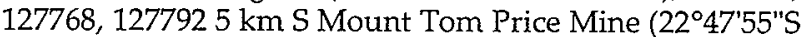
117\%46'10"E); 129587, $129623120 \mathrm{~km}$ NW Newman

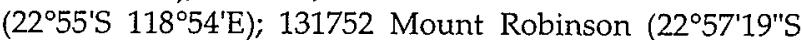

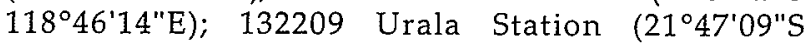
$\left.114^{\circ} 51^{\prime} 58^{\prime \prime E}\right) ; 135322$ Cape Lambert (2045'16"S $\left.117^{\circ} 04^{\prime} 52^{\prime \prime} \mathrm{E}\right) ; 135422$ Mount Brockman (22.18'38"S

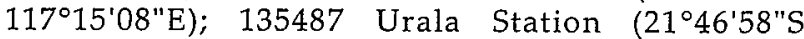

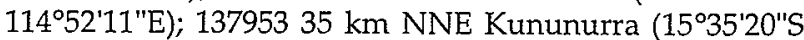

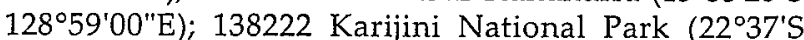
$\left.118^{\circ} 17^{\prime} \mathrm{E}\right) ; 138226 \mathrm{Karijini}$ National Park $\left(23^{\circ} 01^{\prime} \mathrm{S}\right.$ $\left.118^{\circ} 43^{\prime} \mathrm{E}\right) ; 138243$ Karijini National Park (22 ${ }^{\circ} 59^{\prime} \mathrm{S}$ $\left.118^{\circ} 44^{\prime} \mathrm{E}\right) ; 139140$ Meentheena (21⒉ $\left.25^{\prime} 18^{\prime \prime S} 120^{\circ} 25^{\prime} 36^{\prime \prime} \mathrm{E}\right)$; 139282 Meentheena (21ำ $\left.17^{\prime} 07^{\prime \prime} \mathrm{S} 120^{\circ} 24^{\prime} 55^{\prime \prime} \mathrm{E}\right) ; 139308$ Meentheena ( $\left.21^{\circ} 14^{\prime} 41^{\prime \prime S} 120^{\circ} 19^{\prime} 20^{\prime \prime} \mathrm{E}\right) ; 139314$ Meentheena

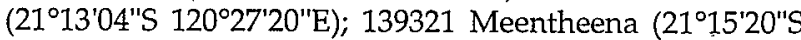
$\left.120^{\circ} 27^{\prime} 18^{\prime \prime} \mathrm{E}\right) ; \quad 139328$ Meentheena (21⒈ $16^{\prime} 54^{\prime \prime S}$ $\left.120^{\circ} 27^{\prime} 58^{\prime \prime E}\right) ; 14127322 \mathrm{~km}$ ESE Port Hedland $\left(20^{\circ} 23^{\prime} \mathrm{S}\right.$

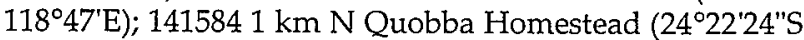
$\left.113^{\circ} 24^{\prime} 19^{\prime \prime} \mathrm{E}\right) ; 141585-86$ Quobba Station (24.027'42"S $\left.113^{\circ} 24^{\prime} 28^{\prime \prime} \mathrm{E}\right) ; 1452505 \mathrm{~km} \mathrm{~S}$ Mount Tom Price Mine

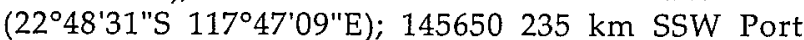

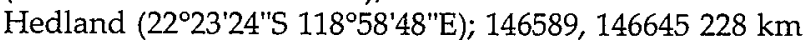
SSW Port Hedland (22 $\left.20^{\prime} 24^{\prime \prime S} 119^{\circ} 00^{\prime} 00^{\prime \prime E}\right) ; 146890$ Mirima National Park (15०47'S $\left.128^{\circ} 44^{\prime} \mathrm{E}\right) ; 146957$ Kalumburu (14ำ $\left.18^{\prime} \mathrm{S} 126^{\circ} 38^{\prime} \mathrm{E}\right) ; 151059-6010 \mathrm{~km} \mathrm{E}$ 
Carnarvon (24.53'S $\left.113^{\circ} 46^{\prime} \mathrm{E}\right) ; 1538142 \mathrm{~km}$ S Yardie

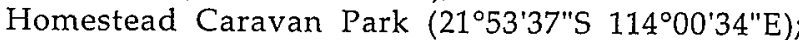

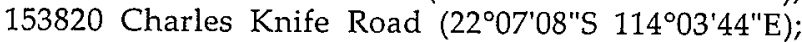

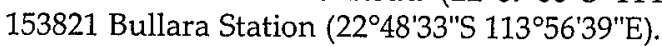

*As noted by Kluge (1974), this locality record is considered erroneous.

Delma sp. incertae sedis

SAM: 5058 Warburton Range (26 $\left.06^{\circ} \mathrm{S} 126^{\circ} 39^{\prime} \mathrm{E}\right)$; WAM: $2520132 \mathrm{~km}$ E Jiggalong (23⒉' $\left.121^{\circ} 05^{\prime} \mathrm{E}\right)$.

Specimens examined in allozyme analysis

Delma pax

WAM: 104297 Woodstock Station; $1200213.5 \mathrm{~km} \mathrm{NE}$ Mount Brockman; 120030 Hope Downs; $12545230 \mathrm{~km} \mathrm{E}$ Newman; 132548 De Grey River Station; 132596, 132606 Burrup Peninsula; 135920 South Hedland; 139171 Cane River Homestead; 139294 Meentheena; 140021 MillsteamChichester National Park; 14127024 km ESE Port Hedland.

Delma desmosa sp nov.

WAM: 102650, 102657 Little Sandy Desert; 114555 Sandfire Roadhouse; 132802 Warri Airstrip; 139089 Mandora; 145073 Officer Basin area.

Delma tealei sp nov.

WAM: 102837 Cape Range National Park; 153811 Charles Knife Road; 1538132 km S Yardie Homestead Caravan Park; 153819 Shothole Canyon.

\section{Delma borea}

WAM: 139058, 139063 Mandora; 141530 Quanbun Downs Station.

Delma tincta

WAM: 102401 Barlee Range Nature Reserve; 102838 Cape Range National Park; 1143919 km NE Broome.

Delma butleri

"western"

WAM: 120819 Peron Peninsula (26 00'S $\left.113^{\circ} 30^{\prime} \mathrm{E}\right)$ 141590 Boolathana Station (24. $\left.39^{\circ} \mathrm{S} 113^{\circ} 42^{\prime} \mathrm{E}\right)$; 127461 East Yuna Nature Reserve $\left(28^{\circ} \cdot 20^{\prime} \mathrm{S} 115^{\circ} 00^{\prime} \mathrm{E}\right) ; 144711$ Bungalbin Hill $\left(30^{\circ} 24^{\prime} \mathrm{S} 119^{\circ} 38^{\prime} \mathrm{E}\right)$

"central"

WAM: 106163 Mount Frazer $\left(25^{\circ} 38^{\prime} \mathrm{S} 118^{\circ} 23^{\prime} \mathrm{E}\right) ; 135249$ Wiluna $\left(26^{\circ} 35^{\prime} \mathrm{S} 120^{\circ} 14^{\prime} \mathrm{E}\right)$; 145072 Officer Basin ( $29^{\circ} 58^{\prime} \mathrm{S}$ $\left.123^{\circ} 46^{\prime} \mathrm{E}\right)$.

SAM: 35027 Bloodweed Bore (265ㄴ $\left.140^{\circ} 57^{\prime} \mathrm{E}\right)$.

"eastern"

SAM: 45210 Peebinga Conservation Park (34 $58^{\prime} \mathrm{S} 140^{\circ}$ $\left.50^{\prime} \mathrm{E}\right)$.

Delma haroldi

WAM: 102123 Mount Windell (22 $\left.{ }^{\circ} 39^{\prime} \mathrm{S} 118^{\circ} 33^{\prime} \mathrm{E}\right)$; 135924

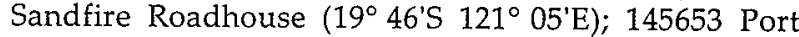
Hedland (20 $\left.18^{\prime} \mathrm{S} 118^{\circ} 35^{\prime} \mathrm{E}\right)$; NTM: 16484 Wave Hill Station $\left(17^{\circ} 29^{\prime} \mathrm{S} 130^{\circ} 57^{\prime} \mathrm{E}\right)$. 
Allozyme profiles for 41 specimens at 34 variable loci

APPENDIX 2

Legend for Museum registration numbers: WAM = Western Australian Museum; NTM = Northern Territory Museum; SAM $=$ South Australian Museum; $(c)=$ "central"; $(w)=$ "western"; $(\mathrm{e})=$ "eastern". A dash indicates the enzyme lacked sufficient activity to determine a profile.

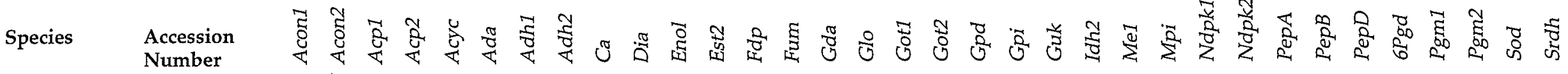

\begin{tabular}{|c|c|c|c|c|c|c|c|c|c|c|c|c|c|c|c|c|c|c|c|c|c|c|c|c|c|c|c|c|c|c|c|c|c|c|c|}
\hline $\operatorname{bax}$ & WAM104297 & a & d & a & $b$ & $a b$ & $\mathrm{~b}$ & $b$ & d & $\mathrm{a}$ & $\mathrm{b}$ & $c$ & $d$ & c & $\mathrm{b}$ & $\mathrm{c}$ & c & $b$ & $b$ & $\mathrm{~b}$ & $b$ & $b$ & C & $c$ & $\mathrm{~b}$ & $\mathrm{a}$ & $\mathrm{b}$ & c & ef & $\mathrm{cd}$ & $\mathrm{b}$ & c & $\mathrm{a}$ & d & b \\
\hline$a x$ & WAM120021 & a & $\mathrm{d}$ & $a$ & $\mathrm{~b}$ & $\mathrm{~b}$ & $b$ & $b$ & $d$ & a & be & $\mathrm{c}$ & de & 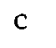 & $\mathrm{b}$ & c & c & $\mathrm{b}$ & $\mathrm{b}$ & $\mathrm{b}$ & $b$ & $a b$ & 0 & 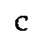 & $\mathrm{b}$ & a & $b$ & $\mathrm{~b}$ & $\mathrm{f}$ & c & bc & c & a & d & $a b$ \\
\hline$a x$ & WAM120030 & a & $\mathrm{d}$ & a & $\mathrm{b}$ & $\mathrm{b}$ & $\mathrm{b}$ & $\mathrm{b}$ & $u$ & . & $\mathrm{e}$ & c & d & 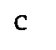 & $\mathrm{b}$ & 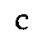 & c & $b$ & 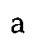 & $\mathrm{b}$ & $\mathrm{b}$ & $\mathrm{b}$ & c & c & $\mathrm{b}$ & 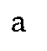 & $\mathrm{b}$ & $\mathrm{b}$ & $\mathrm{f}$ & $\mathrm{cd}$ & $b$ & c & a & $\mathrm{d}$ & $b$ \\
\hline$a x$ & WA & a & $\mathrm{d}$ & $\mathrm{a}$ & $b$ & a & $\mathrm{b}$ & $\mathrm{b}$ & $d$ & $\mathrm{a}$ & be & $\mathrm{c}$ & de & 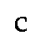 & b & $\mathrm{c}$ & c & $b$ & 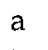 & $b$ & $b$ & $a b$ & 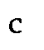 & c & $\mathrm{b}$ & 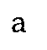 & $\mathrm{b}$ & $\mathrm{b}$ & $f$ & $\mathrm{~d}$ & bc & c & a & dg & $\mathrm{ab}$ \\
\hline$a x$ & WAI & a & $d$ & a & $\mathrm{b}$ & $\mathrm{a}$ & $\mathrm{b}$ & $b$ & $\mathrm{~d}$ & . & $\mathrm{b}$ & $c$ & $\mathrm{~d}$ & c & b & c & c & b & 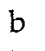 & b & b & $\mathrm{b}$ & & c & $\mathrm{b}$ & & b & c & $\mathrm{f}$ & $\mathrm{cd}$ & b & c & a & $\mathrm{d}$ & 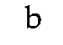 \\
\hline$a x$ & 96 & $a$ & bd & a & $\mathrm{b}$ & $a b$ & $\mathrm{~b}$ & $\mathrm{~b}$ & d & 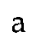 & $b$ & $\mathrm{c}$ & de & c & b & c & $\mathrm{c}$ & b & b & $\mathrm{b}$ & $b$ & $\mathrm{~b}$ & 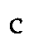 & 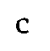 & $\mathrm{b}$ & 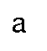 & b & $b c$ & $\mathrm{f}$ & $\mathrm{cd}$ & b & c & a & d & b \\
\hline$a x$ & WA & a & $\mathrm{d}$ & $\mathrm{a}$ & $\mathrm{b}$ & $a b$ & $\mathrm{~b}$ & $\mathrm{~b}$ & $\mathrm{~d}$ & a & $\mathrm{b}$ & $c$ & de & o & b & $c$ & c & $b$ & $\mathrm{~b}$ & $\mathrm{~b}$ & $b$ & $\mathrm{ab}$ & & c & $\mathrm{b}$ & & D & c & $f$ & c & $b c$ & c & a & d & b \\
\hline bax & $\mathrm{W}$ & a & $\mathrm{d}$ & $\mathrm{a}$ & $b$ & $\mathrm{ab}$ & $\mathrm{b}$ & $\mathrm{b}$ & $\mathrm{d}$ & 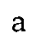 & $\mathrm{b}$ & $\mathrm{c}$ & $\mathrm{d}$ & c & b & c & c & b & $b$ & b & b & $b$ & & c & b & & D & c & $\mathrm{f}$ & $\mathrm{c}$ & b & c & $a$ & $\mathrm{~d}$ & D \\
\hline ax & WA & a & $\mathrm{d}$ & $\mathrm{a}$ & $\mathrm{b}$ & $b$ & b & $\mathrm{b}$ & $d$ & a & $\mathrm{b}$ & $\mathrm{c}$ & e & c & b & $c$ & c & b & $\mathrm{b}$ & $\mathrm{b}$ & b & $\mathrm{b}$ & $c$ & $c$ & b & a & b & b & $\mathrm{f}$ & $\mathrm{cd}$ & $\mathrm{b}$ & c & $\mathrm{a}$ & d & b \\
\hline pax & 94 & a & $\mathrm{d}$ & $\mathrm{a}$ & $\mathrm{b}$ & $b$ & $\mathrm{~b}$ & $\mathrm{~b}$ & $\mathrm{~d}$ & 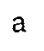 & e & $\mathrm{c}$ & de & - & b & c & c & b & b & b & b & $a b$ & c & 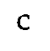 & $b$ & a & D & c & $\mathrm{f}$ & $\mathrm{cd}$ & $\mathrm{b}$ & c & $\mathrm{a}$ & d & b \\
\hline pax & WA & a & $d$ & a & $\mathrm{b}$ & $a b$ & b & $b$ & $\mathrm{~d}$ & $a$ & be & $\mathrm{c}$ & $\mathrm{e}$ & $\mathrm{c}$ & b & $c$ & c & b & b & $b$ & b & b & c & $\mathrm{c}$ & $b$ & a & b & $\mathrm{c}$ & $\mathrm{f}$ & $\mathrm{cd}$ & $b$ & c & $\mathrm{a}$ & d & $\mathfrak{b}$ \\
\hline pax & 270 & a & $\mathrm{d}$ & $\mathrm{a}$ & $b$ & $\mathrm{~b}$ & $b$ & $\mathrm{~b}$ & $\mathrm{~d}$ & . & $\mathrm{b}$ & $c$ & $\mathrm{~d}$ & $c$ & b & c & bc & $a b$ & $b$ & $b$ & $b$ & $a$ & 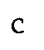 & 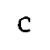 & $b$ & a & $b$ & c & $f$ & $\mathrm{~d}$ & b & $c$ & $\mathrm{a}$ & $\mathrm{d}$ & $\mathrm{b}$ \\
\hline desmosa & 2650 & a & c & a & $\mathrm{b}$ & $\mathrm{b}$ & $\mathrm{b}$ & c & a & $\mathrm{a}$ & $\mathrm{ab}$ & $c$ & d & c & $b$ & $c$ & ac & $\mathrm{b}$ & a & $\mathrm{b}$ & $\mathrm{b}$ & $\mathrm{b}$ & c & c & 2 & a & $D$ & $\mathrm{c}$ & df & $\mathrm{d}$ & $\mathrm{b}$ & $\mathrm{b}$ & 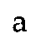 & $\mathrm{d}$ & $\mathrm{b}$ \\
\hline desmosa & 2657 & a & $\mathrm{cd}$ & $\mathrm{a}$ & $\mathrm{b}$ & $\mathrm{b}$ & $\mathrm{b}$ & $c$ & ac & a & $\mathrm{b}$ & c & d & c & $\mathrm{b}$ & c & c & $\mathrm{b}$ & a & $b$ & $\mathrm{~b}$ & $\mathrm{~b}$ & c & $\mathrm{c}$ & $\mathrm{b}$ & $a$ & b & $c$ & $\mathrm{f}$ & $\mathrm{cd}$ & $b$ & $b c$ & a & d & b \\
\hline desmosa & WA & a & $\mathrm{cd}$ & a & $\mathrm{b}$ & $\mathrm{b}$ & $\mathrm{b}$ & $\mathrm{b}$ & c & $a$ & - & $\mathrm{c}$ & - & c & $\mathrm{b}$ & $c$ & c & $\mathrm{b}$ & a & - & $a b$ & $\mathrm{~b}$ & c & $a$ & $\mathrm{~b}$ & a & 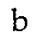 & $\mathrm{c}$ & $\mathrm{f}$ & $\mathrm{cd}$ & $b$ & - & $\mathrm{a}$ & d & - \\
\hline desmosa & WAM132802 & $\mathrm{a}$ & $\mathrm{cd}$ & a & $b$ & $\mathrm{~b}$ & $b$ & $b c$ & ac & 4 & $\mathrm{~b}$ & $c$ & d & c & 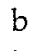 & c & c & b & & - & $\mathrm{b}$ & $\mathrm{b}$ & $\mathrm{c}$ & $\mathrm{c}$ & $\mathrm{b}$ & $a$ & b & c & $\mathrm{f}$ & $\mathrm{cd}$ & $\mathrm{b}$ & c & $a$ & d & \\
\hline lesmosa & WAM139089 & a & $\mathrm{cd}$ & a & $\mathrm{b}$ & $b$ & $\mathrm{~b}$ & c & c & a & a & $\mathrm{C}$ & d & bc & $\mathrm{b}$ & $c$ & ac & $\mathrm{b}$ & a & $\mathrm{b}$ & $\mathrm{b}$ & $b$ & c & $\mathrm{a}$ & $b$ & a & $\mathrm{b}$ & c & $\mathrm{f}$ & c & $\mathrm{b}$ & c & a & $\mathrm{d}$ & \\
\hline esmosa & WAM145073 & $\mathrm{a}$ & c & $\mathrm{a}$ & $\mathrm{b}$ & $b$ & $b c$ & c & $\mathrm{a}$ & $a$ & $b$ & $\mathrm{c}$ & $\mathrm{d}$ & c & $\mathrm{b}$ & $\mathrm{c}$ & c & $\mathrm{b}$ & a & $b$ & $\mathrm{~b}$ & $b$ & c & $\mathrm{c}$ & $\mathrm{b}$ & a & $c$ & c & $f$ & d & $b$ & c & $\mathrm{a}$ & d & $\mathrm{b}$ \\
\hline
\end{tabular}




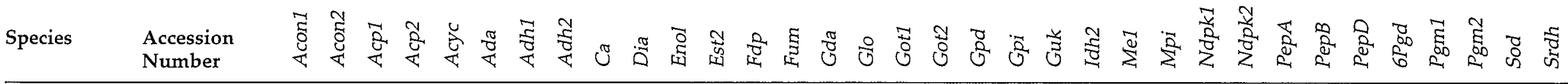

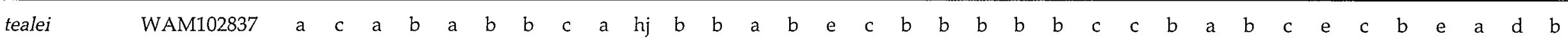

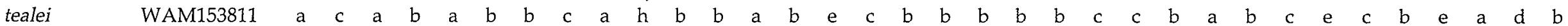

tealei

tealei

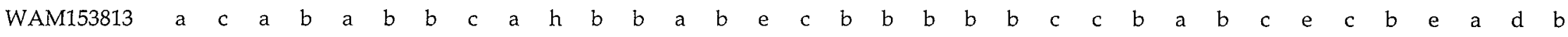

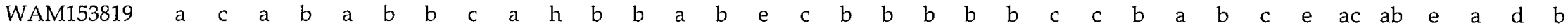

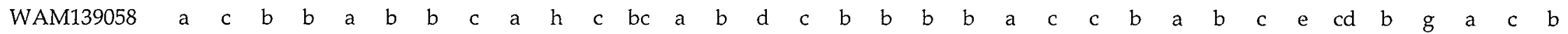

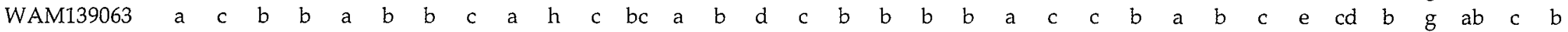

borea

borea

WAM141530

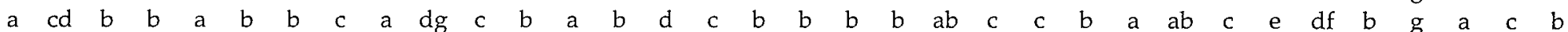

tincta

tincta

WAM102401

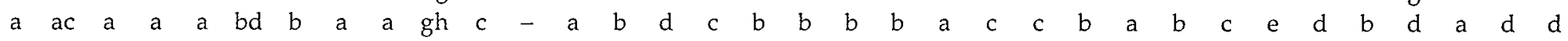

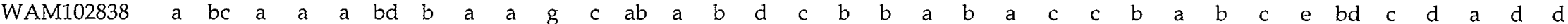

tincta

WAM114391

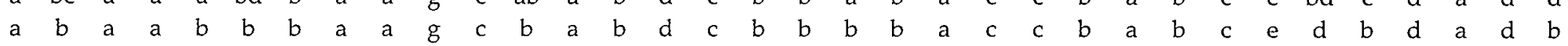

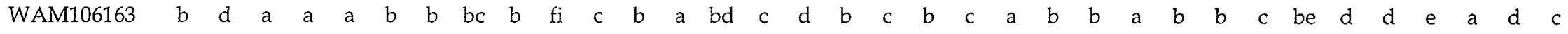

butleri (w)

WAM120819

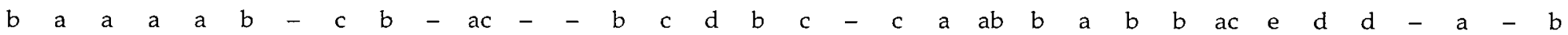

butleri $(w)$

butleri (c)

butleri (w)

butleri (w)

WAM127461

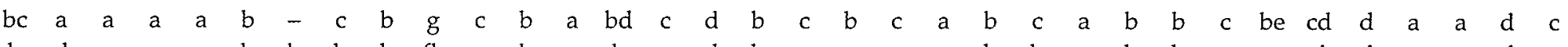

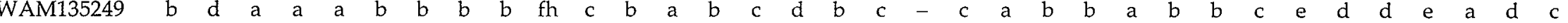

butleri (c)

WAM141590

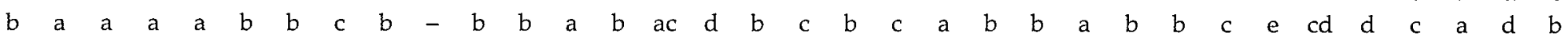

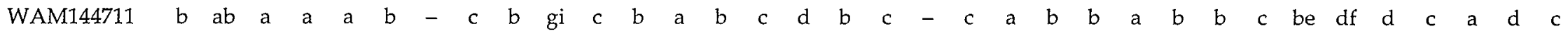

butleri (e)

WAM14507

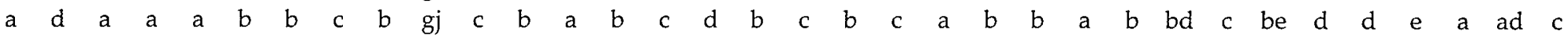

butleri $(\mathrm{c})$

SAM 45210

haroldi

harold

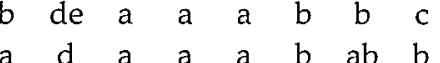

WAM102123

harold

WAM145653

haroldi NTM16484

$a b$ ad $a$ a $a c \quad b$

$\begin{array}{lll}b & b & b \\ b & b & b\end{array}$

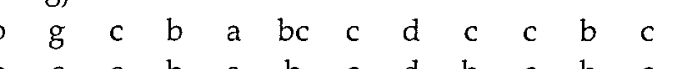

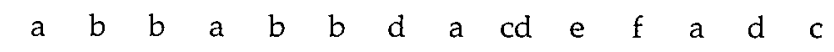

$\begin{array}{llllllllllllll}a & b & b & a & b & b & c & b e & d & d & \text { ef } & a & a d & c\end{array}$

$\begin{array}{lllllllll}b & b & c & a c & d g & d & a & a & c\end{array}$

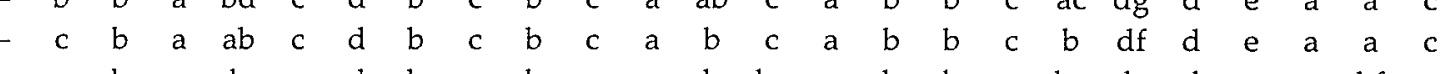
b $b \quad-$

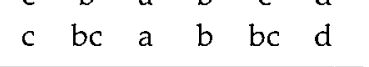

